DOC.20040908.0005

QA: QA

ANL-NBS-GS-000008 REV 01

September 2004

\title{
Future Climate Analysis
}

Prepared for:

U.S. Department of Energy

Office of Civilian Radioactive Waste Management

Office of Repository Development

1551 Hillshire Drive

Las Vegas, Nevada 89134-6321

Prepared by:

Bechtel SAIC Company, LLC

1180 Town Center Drive

Las Vegas, Nevada 89144

Under Contract Number

DE-AC28-01RW12101 


\section{DISCLAIMER}

This report was prepared as an account of work sponsored by an agency of the United States Government. Neither the United States Government nor any agency thereof, nor any of their employees, nor any of their contractors, subcontractors or their employees, makes any warranty, express or implied, or assumes any legal liability or responsibility for the accuracy, completeness, or any third party's use or the results of such use of any information, apparatus, product, or process disclosed, or represents that its use would not infringe privately owned rights. Reference herein to any specific commercial product, process, or service by trade name, trademark, manufacturer, or otherwise, does not necessarily constitute or imply its endorsement, recommendation, or favoring by the United States Government or any agency thereof or its contractors or subcontractors. The views and opinions of authors expressed herein do not necessarily state or reflect those of the United States Government or any agency thereof. 
QA: QA

Future Climate Analysis

ANL-NBS-GS-000008 REV 01

September 2004 


\begin{tabular}{|l|l|l|}
\hline \multirow{2}{*}{ OCRWM } & Scientific Analysis Signature Page/ Change History & Page iii \\
\cline { 3 - 3 } & & 1. Total Pages: 102 \\
\hline
\end{tabular}

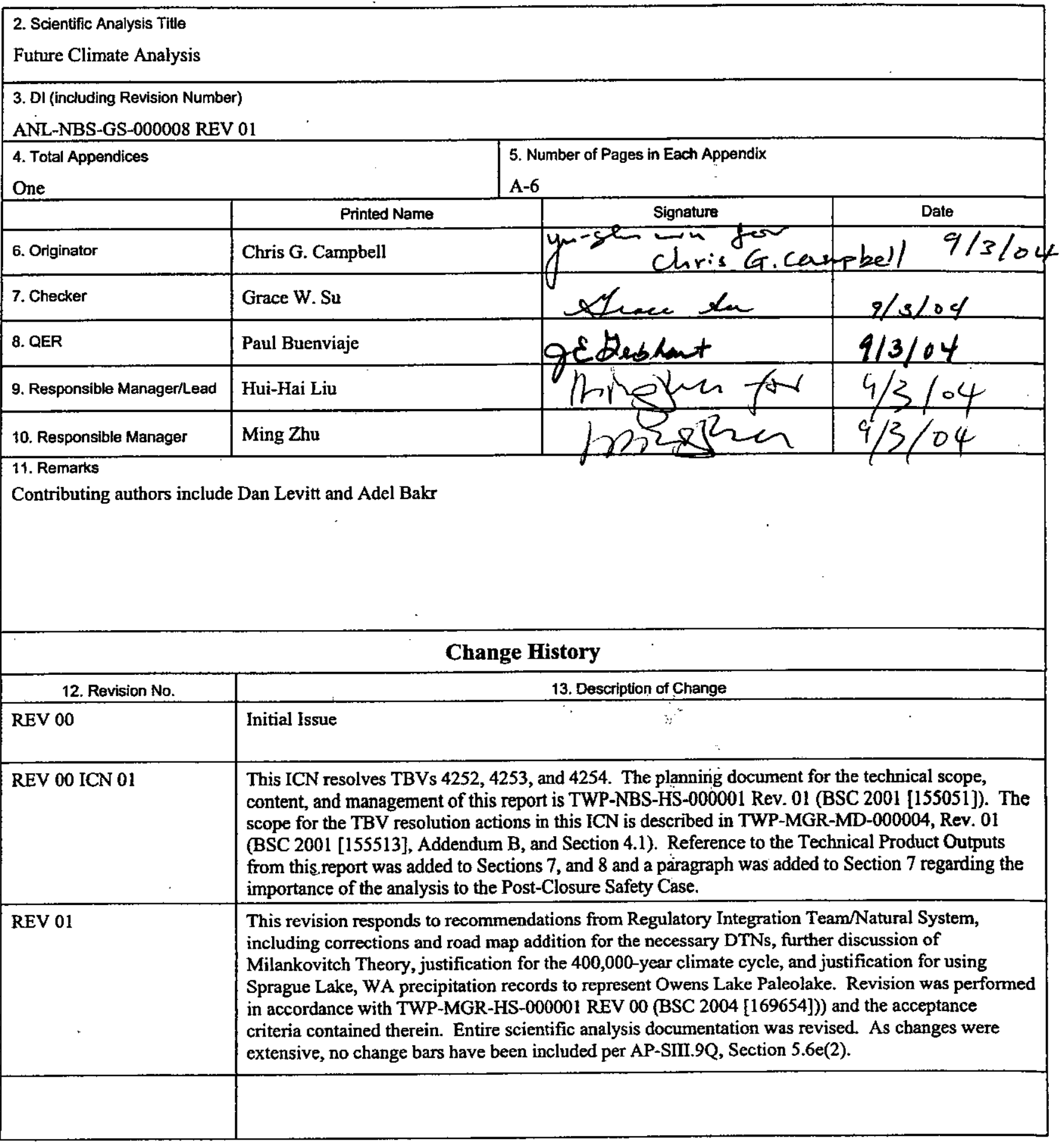




\section{CONTENTS}

Page

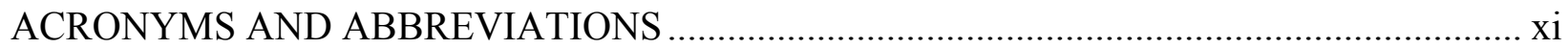

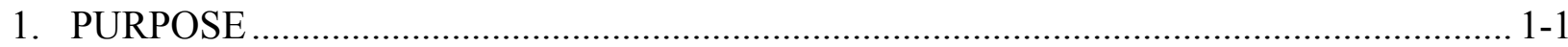

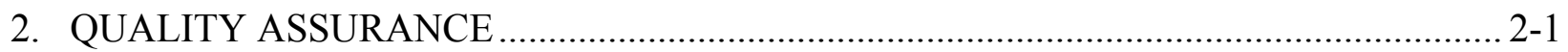

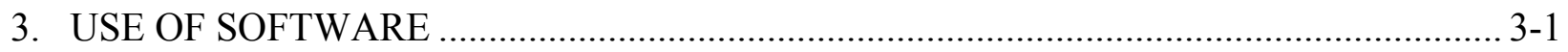

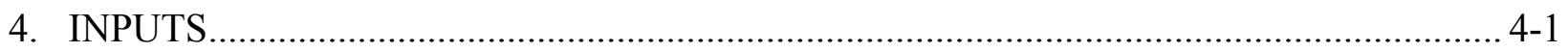

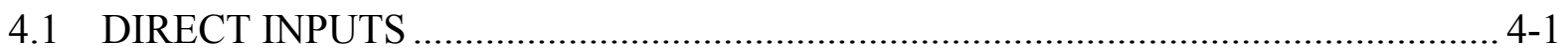

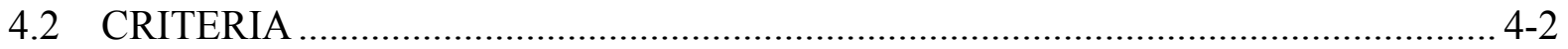

4.3 CODES, STANDARDS, AND REGULATIONS ................................................. 4-3

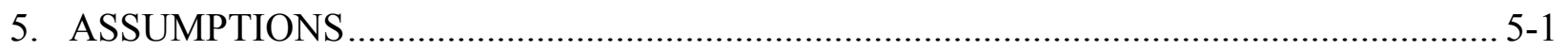

6. SCIENTIFIC ANALYSIS DISCUSSION ......................................................................... 6-1

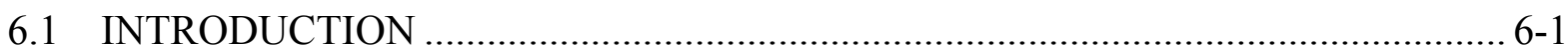

6.2 PRESENT-DAY AND PAST CLIMATES ………………………………….......... 6-1

6.3 THE CYCLICAL NATURE OF CLIMATE CHANGE-DEVILS HOLE .................. 6-6

6.4 TIMING OF PAST-CLIMATE CHANGE AND EARTH-ORBITAL

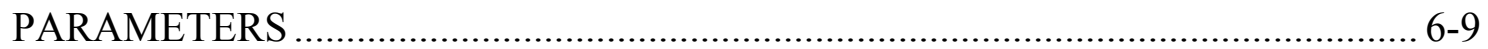

6.5 THE NATURE OF PAST AND FUTURE CLIMATE.......................................... 6-25

6.5.1 Basis for and General Climate History of the Last 400,000 Years.................. 6-25

6.5.2 Repetition of Past Climates....................................................................... 6-35

6.5.2 Repetition of Past Climates.......................................................................... 6-36

6.6 A FUTURE CLIMATE ANALOG FOR THE NEXT 10,000 YEARS ..................... 6-39

6.6.1 Timing of Climate Change for the Next 10,000 Years.................................. 6-39

6.6.2 The Nature of Future Climate Change.......................................................... 6-46

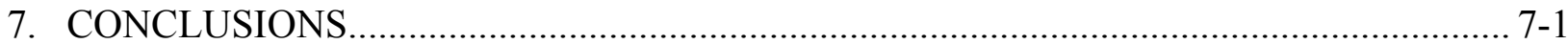

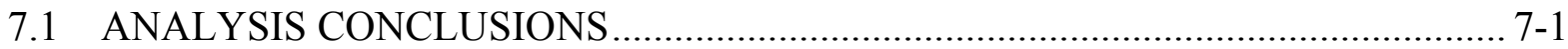

7.2 APPLICABLE ACCEPTANCE CRITERIA.............................................................. 7-3

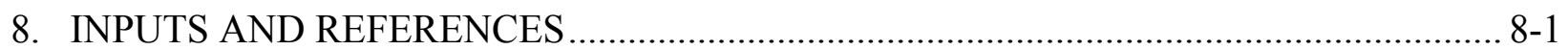

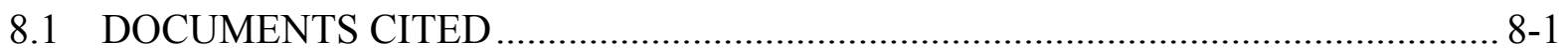

8.2 CODES, STANDARDS, REGULATIONS, AND PROCEDURES ……………........ 8-8

8.3 SOURCE DATA, LISTED BY DATA TRACKING NUMBER ………................... 8-8

8.4 OUTPUT DATA, LISTED BY DATA TRACKING NUMBER ………………........ 8-9

APPENDIX A: INTERNAL QUALIFICATIONS .................................................... A-1 


\section{INTENTIONALLY LEFT BLANK}




\section{FIGURES}

Page

6-1. Western United States Showing Localities Discussed in the Text ............................ 6-2

6-2. Generalized View of Atmospheric Circulation.................................................... 6-3

6-3. Devils Hole Stable Isotope Record Showing the Timing and Cyclical Nature of

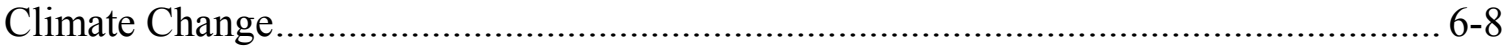

6-4. Generalized View of Precession, an Orbital Parameter Related to the Timing of Earth's Long-Term Climate Change

6-5. Relation Between Precession (Earth wobble every 23,000 years) and Eccentricity (shape of Earth orbit $\sim 100,000$ years, time-scale) for the Past 425,000 Years

6-6. Relation of Precession to the Devils Hole Stable Isotope Climate Proxy Record During a Long Climate Cycle

6-7. Proposed Relation Between the Timing of Past Climate Change and Earth-Orbital Parameters During a Long Climate Cycle; Continuation of Diagram is Given as Figure 6-8.

6-8. Continued from Figure 6-7; Proposed Relation Between the Timing of Past Climate Change and Earth-Orbital Parameters During a Long Climate Cycle 6-17

6-9. Relation of Data Shown in Figures 6-7 and 6-8 and the Timing of Climate Change Defined by the Devils Hole Climate Proxy Record

6-10. Proposed Timing of Future Climate Change During the Next 100,000 Years

6-11. Relation Between Precession and the Timing of Climate Change in Part of the Devils Hole Record from 425,000 to 350,000 Years Ago....

6-12. Owens Lake Ostracode Species Stratigraphic Distribution

6-13. Present-day Biogeographic Distribution of Two Ostracode Species Found in the Owens Lake Fossil Record Illustrating a Relation Between Biogeography and General Features of Climate (Figure 6-2)

6-14. Generalized Depiction of the Present-Day Average Distribution of the Southwestern Monsoon.

6-15. Stratigraphic Distribution of Ostracodes in Part of the Owens Lake Record Used for the Future Climate Analog $6-43$

6-16. Meteorological Stations Selected (Table 6-1) to Represent Future Climate States at Yucca Mountain, Nevada. 


\section{INTENTIONALLY LEFT BLANK}




\section{TABLES}

Page

4-1. $\quad$ Summary of Data Sets Used as Data Inputs ..................................................... 4-1

4-2. Acceptance Criteria Applicable to this Analysis Report .............................................. 4-2

6-1. Meteorological Stations Selected to Represent Future Climate States at Yucca

Mountain, Nevada. 


\section{INTENTIONALLY LEFT BLANK}




\section{ACRONYMS AND ABBREVIATIONS}

$\mathrm{AC}$

acceptance criteria

DTN

data tracking number

FEPs

features, events, and processes

MAP

mean annual precipitation

MAT

mean annual temperature

OIS

oxygen isotope stages

OLCC

older long climate cycle

SPECMAP

spectral coordinate map of climate times series of the past 400,000 years derived for 17 sediment cores from the Atlantic Ocean.

TDS

total dissolved solids

TSPA

total system performance assessment

YLCC younger long climate cycle 


\section{INTENTIONALLY LEFT BLANK}




\section{PURPOSE}

This report documents an analysis that was performed to estimate climatic variables for the next 10,000 years by forecasting the timing and nature of climate change at Yucca Mountain, Nevada (Figure 6-1), the site of a repository for spent nuclear fuel and high-level radioactive waste. The future-climate estimates are based on an analysis of past-climate data from analog meteorological stations, and this report provides the rationale for the selection of these analog stations. The stations selected provide an upper and a lower climate bound for each future climate, and the data from those sites will provide input to the following reports: Simulation of Net Infiltration for Present-Day and Potential Future Climates (BSC 2004 [DIRS 170007]), Total System Performance Assessment (TSPA) Model/Analysis for the License Application (BSC 2004 [DIRS 168504]), Features, Events, and Processes in UZ Flow and Transport (BSC 2004 [DIRS 170012]), and Features, Events, and Processes in SZ Flow and Transport (BSC 2004 [DIRS 170013]).

Forecasting long-term future climates, especially for the next 10,000 years, is highly speculative and rarely attempted. A very limited literature exists concerning the subject, largely from the British radioactive waste disposal effort. The discussion presented here is one available forecasting method for establishing upper and lower bounds for future climate estimates. The selection of different methods is directly dependent on the available evidence used to build a forecasting argument. The method used here involves selecting a particular past climate from many past climates, as an analog for future climate. While alternative analyses are possible for the case presented for Yucca Mountain, the evidence (data) used would be the same and the conclusions would not be expected to drastically change. Other studies might develop a different rationale or select other past climates resulting in a different future climate analog. Other alternative approaches could include simulation of climate over the 10,000-year period; however, this modeling extrapolation is well beyond the bounds of current scientific practice and would not provide results with better confidence. A corroborative alternative approach may be found in Future Climate Analysis-10,000 Years to 1,000,000 Years After Present (Sharpe 2003 [DIRS 161591]). The current revision of this report is prepared in accordance with Technical Work Plan for: Unsaturated Zone Flow Analysis and Model Report Integration (BSC 2004 [DIRS 169654]). 


\section{INTENTIONALLY LEFT BLANK}




\section{QUALITY ASSURANCE}

Revision 01 has been developed in accordance with AP-SIII.9Q, Scientific Analyses. Development of this report and the supporting activities are subject to the Yucca Mountain Project's quality assurance program as indicated in Technical Work Plan for: Unsaturated Zone Flow Model Report Integration (BSC 2004 [DIRS 169654], Section 8.1). Approved quality assurance procedures identified in Section 4 of the technical work plan have been used to conduct and document the activities described in this report. Section 8.4 of the technical work plan also identifies the methods used to control the electronic management of data during the modeling and documentation activities.

This report examines the future climate conditions that are identified as natural barriers that are classified in the Q-List (BSC 2004 [DIRS 168361]) as "Safety Category" because they are important to waste isolation, as defined in AP-2.22Q, Classification Analyses and Maintenance of the Q-List. The report contributes to the analysis and modeling data used to support performance assessment (PA). The conclusions of this model report do not affect the proposed repository design or engineered features important to safety, as defined in AP-2.22Q. 


\section{INTENTIONALLY LEFT BLANK}




\section{USE OF SOFTWARE}

Microsoft Excel 2000 was used in this analysis for the development of graphic representations. Microsoft Excel 2000 is exempt software application in accordance with Section 2.1.2 of LP-SI.11Q -BSC, Software Management. No other software or models were used in development of this analysis. 


\section{INTENTIONALLY LEFT BLANK}




\section{INPUTS}

This section documents inputs used for future climate analysis.

\subsection{DIRECT INPUTS}

Data sets used in this analysis are summarized in Table 4-1.

Table 4-1. Summary of Data Sets Used as Data Inputs

\begin{tabular}{|l|l|}
\hline \multicolumn{1}{|c|}{ Data Inputs } & \multicolumn{1}{|c|}{ Data Tracking Number } \\
\hline Diatom Data from Owens Lake 1984-1992 Cores & $\begin{array}{l}\text { GS030908315121.001 } \\
\text { [DIRS 171152] }\end{array}$ \\
\hline $\begin{array}{l}\text { Ostracode Data from Owens Lake 1984-1992 Cores } \\
\text { Supplementary Data to Ostracode Data From Owens Lake 1984 - 1992 Cores }\end{array}$ & $\begin{array}{l}\text { GS970708315121.002 } \\
\text { [DIRS 106508] }\end{array}$ \\
\hline $\begin{array}{l}\text { [DIRS 168533]. } \\
\text { Supplementary Data to Diatom Data From Owens Lake 1984 - 1992 Cores }\end{array}$ & $\begin{array}{l}\text { GS031108315121.002 } \\
\text { [DIRS 170227]. }\end{array}$ \\
\hline $\begin{array}{l}\text { Earthinfo, Inc. Western U.S. Meteorologic Station weather Data - NCDC } \\
\text { Summary of Day (West 1) and NCDC Summary of Day (West 2) }\end{array}$ & $\begin{array}{l}\text { GS000100001221.001 } \\
\text { [DIRS 146816]. }\end{array}$ \\
\hline $\begin{array}{l}\text { Earth-orbital Parameter Data for the Present to 100,000 years in the Future } \\
\text { Earth-orbital Parameter Data for the Last 10 Million years }\end{array}$ & $\begin{array}{l}\text { GS000200005121.002 } \\
\text { [DIRS 146817] }\end{array}$ \\
\hline $\begin{array}{l}\text { Radiometric Dating and } \delta^{18} \text { O Data from Devils Hole, Nevada } \\
\text { Calibrating Late Quaternary Terrestrial Climate Signals: Radiometrically Dated } \\
\text { Pollen Evidence from the Southern Sierra Nevada, USA (Litwin et al. 1999) }\end{array}$ & $\begin{array}{l}\text { GS000200005121.001 } \\
\text { [DIRS 146818] }\end{array}$ \\
\hline
\end{tabular}

NCDC $=$ National Climate Data Center

These data sets were used to provide a rationale for a specific set of climates and a basis for other analyses and models to evaluate uncertainty within the confines of these climate characteristics. The objective was to determine whether this degree of climate change is adverse to the site. The parameters of past climate were used for a select set of representative meteorological stations to estimate values for future climates. These parameters are appropriate because they are the input parameters needed for the analysis of infiltration at the site. Specifically, the appropriateness of the data inputs listed in Table 4-1 dealing with the diatom, ostracode, and depth to age relationship data are discussed in Section 6.5. The appropriateness of data inputs covering radiometric dating from Devils Hole, Nevada, is discussed in Section 6.3; for data inputs summarizing the day observations from the National Climatic Data Center, the appropriateness is discussed in Section 6.6; and for the earth orbital parameter data, it is discussed in Section 6.4.

"Calibrating Late Quaternary Terrestrial Climate Signals: Radiometrically Dated Pollen Evidence from the Southern Sierra Nevada, USA" (Litwin et al. 1999 [DIRS 109440]) is internally qualified as direct input in this document according to AP-SIII.9Q. The detail justification is provided in Appendix A. 


\subsection{CRITERIA}

The general requirements to be satisfied by TSPA are stated in 10 CFR 63.114 [DIRS 156605] (Requirements for Performance Assessment). Technical requirements to be satisfied by TSPA are identified in Project Requirements Document (Canori and Leitner 2003 [DIRS 166275]). The acceptance criteria that will be used by the U.S. Nuclear Regulatory Commission (NRC) to determine whether the technical requirements have been met are identified in Yucca Mountain Review Plan, Final Report (NRC 2003 [DIRS 163274]). The pertinent criteria and subcriteria for this scientific report are identified in Section 2.2.1.3.5.3, Acceptance Criteria (for 2.2.1.3.5, Climate and Infiltration), which are based on meeting the requirements of 10 CFR 63.114 (a)-(c) and (e)-(g), relating to Climate and Infiltration model abstraction.

Table 4-2. Acceptance Criteria Applicable to this Analysis Report

\begin{tabular}{|c|c|c|c|}
\hline $\begin{array}{c}\text { Requirement } \\
\text { Number }\end{array}$ & Requirement Title & $\begin{array}{l}10 \text { CFR } 63 \\
\text { Link }^{\mathrm{a}}\end{array}$ & Applicable Criteria \\
\hline PRD-002/T-026 & $\begin{array}{l}\text { Requirements for Performance } \\
\text { Assessment }\end{array}$ & $\begin{array}{l}10 \text { CFR } 63.305 \\
40 \text { CFR } 197.15\end{array}$ & $\begin{array}{l}\text { Criteria } 1 \text { and } 2 \text { for Climate and } \\
\text { Infiltration apply to } 10 \text { CFR } 63.114 \text { (a)- } \\
\text { (c) and (e)-(g) }\end{array}$ \\
\hline
\end{tabular}

${ }^{a}$ from Canori and Leitner (2003 [DIRS 166275])

b10 CFR 63 [DIRS 156605]

from NRC (2003 [DIRS 163274]), Section 2.2.1.3.5.1

In cases where subsidiary criteria are listed in the YMRP for a given criterion, only the subsidiary criteria addressed by this scientific analysis are listed below. Applicable acceptance criteria identified in Section 2.2.1.3.5 (Climate and Infiltration) of the YMRP (NRC, 2003 [DIRS 163274]) are listed below.

\section{Acceptance Criterion 1, System Description and Model Integration are Adequate}

(1) The total system performance assessment adequately incorporates, or bounds, important design features, physical phenomena, and couplings, and uses consistent and appropriate assumptions throughout the climate and net infiltration abstraction process

(2) The aspects of geology, hydrology, geochemistry, physical phenomena, and couplings, that may affect climate and net infiltration, are adequately considered. Conditions and assumptions in the abstraction of climate and net infiltration are readily identified and consistent with the body of data presented in the description

(3) The abstraction of climate and net infiltration uses assumptions, technical bases, data, and models that are appropriate and consistent with other related U.S. Department of Energy abstractions. For example, the assumptions used for climate and net infiltration Review Plan for Safety Analysis Report 2.2-61 are consistent with the abstractions of flow paths in the unsaturated zone and flow paths in the saturated zone (Sections 2.2.1.3.6 and 2.2.1.3.8 of the YMRP, respectively). The descriptions and technical bases provide transparent and traceable support for the abstraction of climate and net infiltration 
(4) Sufficient data and technical bases to assess the degree to which features, events, and processes have been included for this abstraction are provided

(7) Projections of future climate change are based on evaluation of paleoclimate information over the past 500,000 years. For example, numerical climate models, if used for projection of future climate, are calibrated based on such paleoclimate data

(8) Guidance in NUREG-1297 (Altman et al. 1988 [DIRS 103597]) and NUREG1298 (Altman et al. 1988 [DIRS 103750]), or other acceptable approaches for peer reviews and data qualification, is followed.

Acceptance Criterion 2, Data are Sufficient for Model Justification

(1) Climatological and hydrological values used in the license application (e.g., time of onset of climate change, mean annual temperature, mean annual precipitation, mean annual net infiltration, etc.) are adequately justified. Adequate descriptions of how the data were used, interpreted, and appropriately synthesized into the parameters are provided

\subsection{CODES, STANDARDS, AND REGULATIONS}

No specific, formally established codes, standards, or regulations have been identified as applying to this analysis. 


\section{INTENTIONALLY LEFT BLANK}




\section{ASSUMPTIONS}

The following four key assumptions are fundamental to the future climate analysis. The basis for each assumption is discussed in Section 6, except for Assumption 4, which is assumed for the time frame in question.

1. Climate is cyclical, so past climates provide insight into potential future climates (Section 6.3).

2. A relation exists between the timing of long-term past climate change (the glacial/interglacial cycles) and the timing of changes in certain earth-orbital parameters according to the Milankovitch Theory. This establishes a millennial-scale, climate-change clock, which provides a possible way to time future climate change (Section 6.4).

3. A relation exists between the characteristics of past climates and the sequence of those climates in the long, approximately 400,000-year, earth-orbital cycle. The characteristics of past glacial and interglacial climates within the long earth-orbital cycle differ from each other, and appear to do so in a systematic way. This climate sequence relation provides a defensible criterion for the selection of a particular past climate as an analog for future climate (Section 6.5).

4. Long-term earth-based climate forcing functions, primarily tectonics, that operate on the million-year time scale have remained relatively unchanged during the last long earth climate cycle, and will not change during the next 10,000 years. Consequently, the potential and unpredictable impact of long-term, earth-based forcing functions on climate need not be considered for understanding climate change during the past 400,000 years or the next 10,000 years.

Under these assumptions, future climate is determined by orbital forcing (Milankovitch Forcing) and geographic effects. The first three assumptions cannot be confirmed by testing, analysis, or design because of the inherent nature of estimating or predicting future climate states, however, evidence from the scientific literature supporting them is presented in Section 6. The second assumption builds on the first, and the third builds on the second. As such, the future climate forecast presented represents the best available approach based on the current scientific knowledge.

Assumption 4-that long-term, earth-based forcing functions will not change during the next 10,000 years, and therefore, impacts on climate need not be considered for understanding climate change during the next 10,000 years-is consistent with U.S. Environmental Protection Agency (EPA) final rule 40 CFR 197 [Public Health and Environmental Radiation Protection Standards for Yucca Mountain, NV; Final Rule (EPA 2001 [DIRS 155238], p. 32097)]. Regarding the 10,000-year compliance period, the EPA states (2001 [DIRS 155238], p. 32097), "(2) There are likely to be no exceptionally large geologic changes during that time". NRC final rule for geological disposal of high-level radioactive wastes at Yucca Mountain is consistent with environmental standards for Yucca Mountain issued by EPA (NRC 2001 [DIRS 156605], p. 55732]). NRC (2001 [156605], Section 63.305 (c)) also indicates that variations in climate must 
be consistent with, among other things, present knowledge of factors (such as geology) that would affect Yucca Mountain. As noted above, long-term earth-based climate forcing functions, primarily tectonics, that operate on the million-year time scale have remained relatively unchanged during the last long earth climate cycle.

In addition to these major assumptions, temperature and precipitation records are used from representative sites to characterize forecasted future conditions at Yucca Mountain. Therefore, it is assumed that differences in the locations selected and Yucca Mountain during the future climate states are on average not significant. These selected locations are: Nogales, Arizona, and Hobbs, New Mexico, for the monsoon climate state and Spokane, Rosalia, and St. John, Washington, as well as Beowawe, Nevada, and Delta, Utah, for the glacial climate state. 


\section{SCIENTIFIC ANALYSIS DISCUSSION}

\subsection{INTRODUCTION}

Past climate was analyzed to select representative meteorological stations that can be used to estimate climate values for future climates, such as mean annual and seasonal precipitation, and mean annual and seasonal air temperature, at Yucca Mountain, Nevada for the next 10,000 years. This approach is referred to as climate forecasting, where climate is expected to evolve in repeating cycles so that past climate records may be used as the basis for projecting approximate future conditions. These climate values then provide the input terms for the infiltration model (BSC 2004 [DIRS 170007]) at Yucca Mountain. The analysis depends on the assumptions (mentioned in Section 5) of climate cyclicity, of the accuracy of an earth-orbital parameter climate-change clock, of the repetition of particular past climate states in the future, and of relative tectonic stability during the past long earth-orbital cycle and for the next 10,000 years. The basis for each of the first three assumptions is discussed below along with the general nature of present-day climate, which serves as a reference for comparison with past climates. The constancy of tectonic scale climate change will be assumed for the 10,000-year time frame, but cannot be assumed for million-year time scales past or future.

This report addresses the following features, events, and processes (FEPs) as taken from the LA-FEP list in data tracking number (DTN) MO0407SEPFEPLA.000 [DIRS 170760]. The selected FEP, FEP 1.3.01.00.0A: Climate Change, is directly associated with the subject matter of this report. It is included through the use of the output of this AMR, which provides the forecast for future climate states, the timing of those states, and the magnitude of the changes in temperature and precipitation associated with long term climate change. The information relevant to the treatment of this FEP is addressed in Sections 6.6 and 7.1.

The causes of climate change in the past between glacial and interglacial conditions are not known, but this analysis attempts to establish timing relations between earth-orbital parameters that can be calculated and climate-cycle relations that can be recognized from the past and used to forecast the future. Any future climate analysis is uncertain, but perceived relations between measurable cycles enable an attempt to forecast estimated future climate conditions.

A map of the western United States showing the locations of specific sites discussed in this report is provided in Figure 6-1 and Figure 6-16.

\subsection{PRESENT-DAY AND PAST CLIMATES}

A generalized schematic of present-day atmospheric circulation (climate) is shown in Figure 6-2. For the purposes of this analysis, the present-day earth climate system may be thought of as a three-component system, consisting of two active components, the tropical (Hadley) and polar cell air masses, and of a more passive mixing zone between them, the westerlies (Ferrel cell). The northern edge of the tropical air masses, the Subtropical Highs, consist of high-pressure, descending air that creates a hot, dry and, hence, low precipitation and high evaporation climate. The Subtropical Highs define the global hot desert belts and dominate the climate of the Yucca Mountain region today. Regions south of the Subtropical Highs fall under the influence of the much wetter subtropical easterlies. 


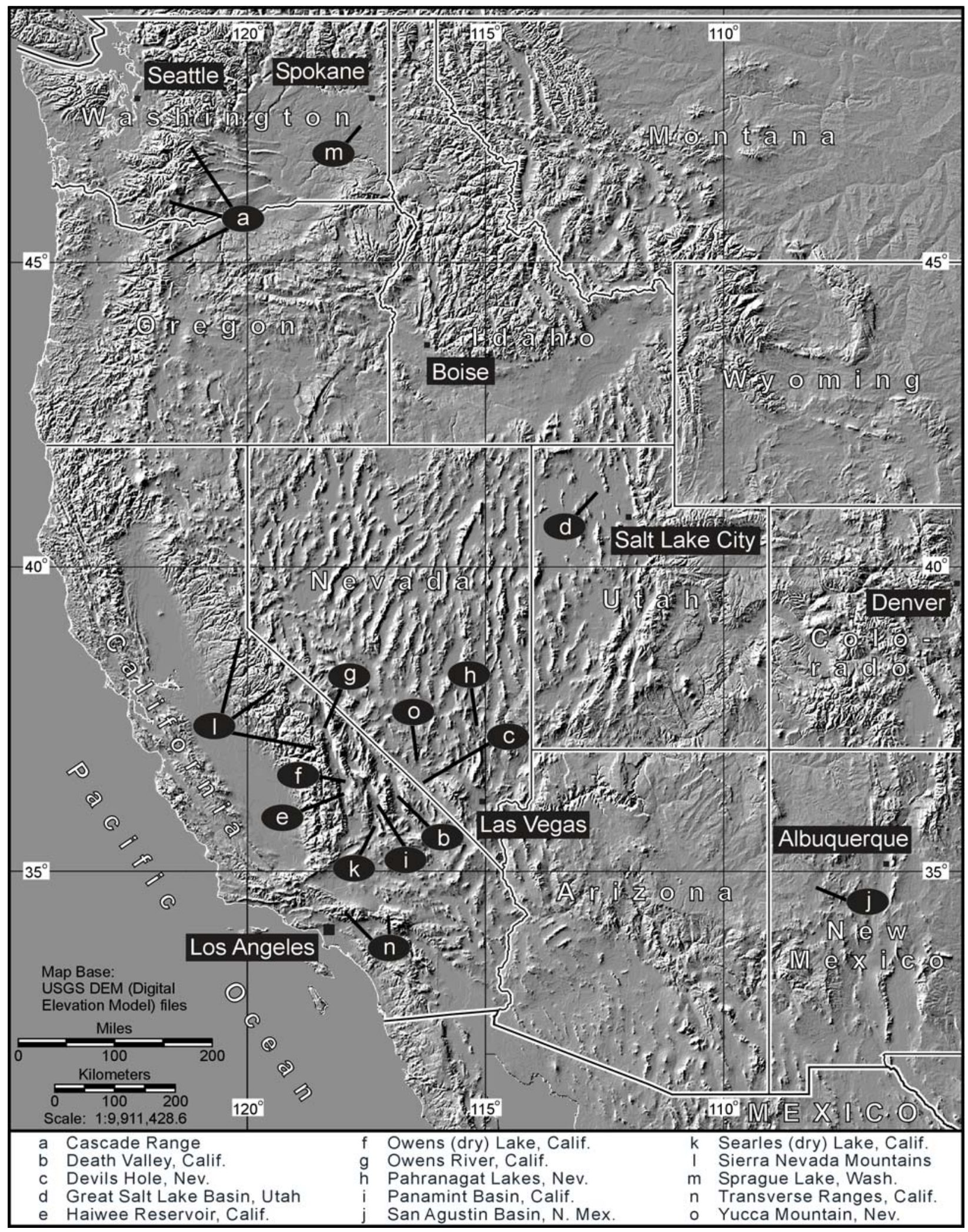

Figure 6-1. Western United States Showing Localities Discussed in the Text 


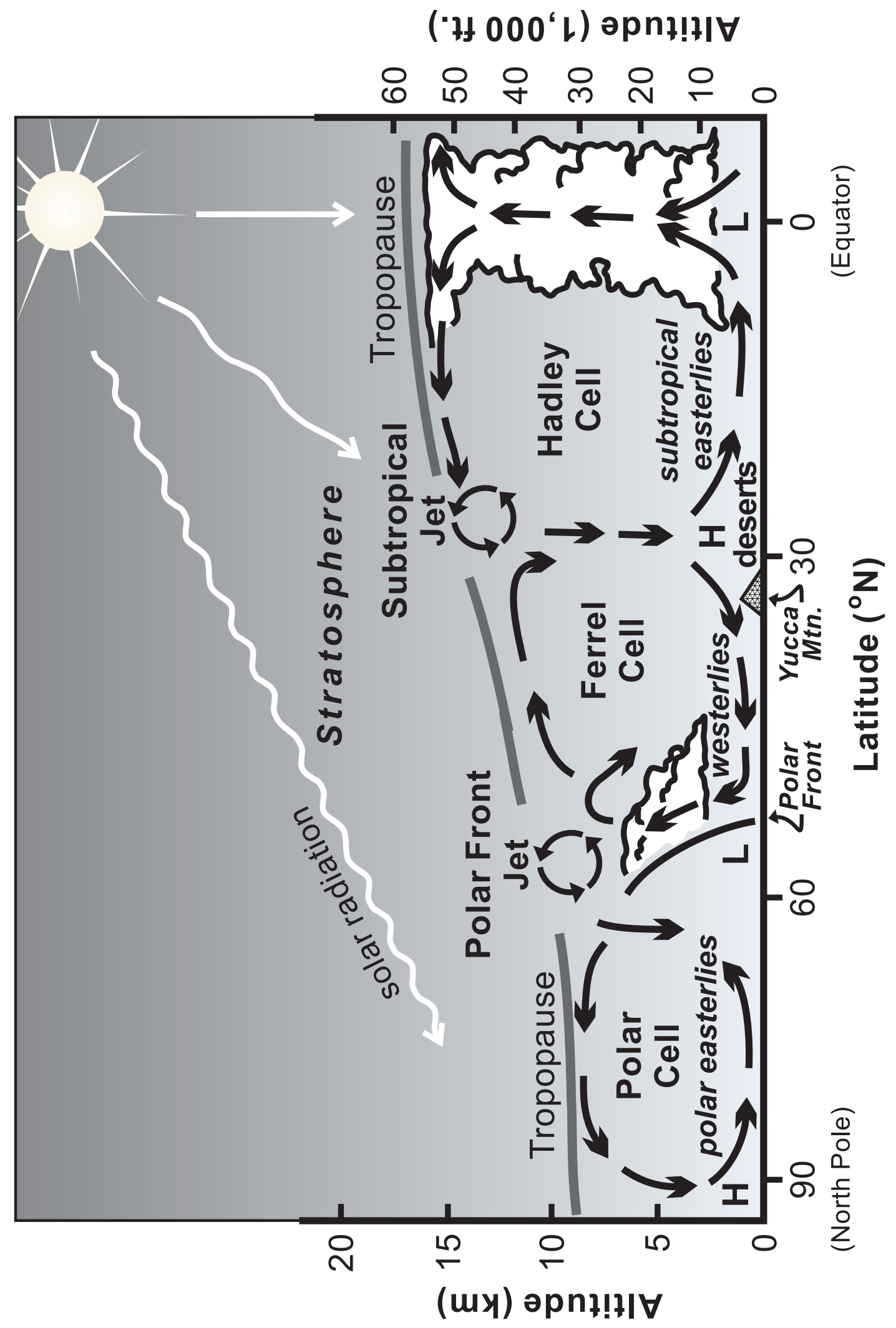

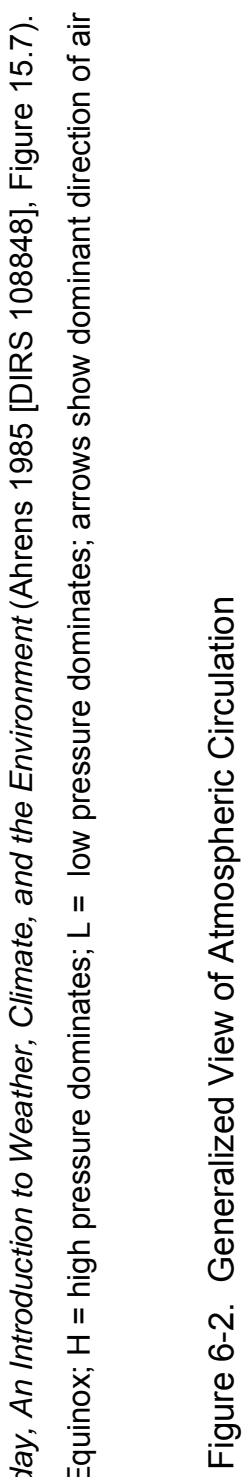


The southern edge of the polar air masses, the Polar Lows, consist of low-pressure, rising air that creates a cool, wet and, hence, high precipitation and low evaporation climate. The average seasonal position of the Polar Lows approximately defines the Boreal Forests and also dominated some past glacial climates in the Yucca Mountain region. The central (northernmost) part of the polar air mass is characterized, especially in winter, by dense, cold, descending air creating lower tropospheric high-pressure cells. Air streams flow southward from these high-pressure cells producing the Arctic (Polar) easterlies. Arctic (Polar) Highs are typically characterized by cold, dry air, and hence low-precipitation and low-evaporation climates. The Arctic Highs also dominated some past glacial climates in the Yucca Mountain region.

The mixing zone between the tropical and polar air masses, the westerlies, have a complex weather system consisting of high- and low-pressure air masses or cells that often produce storms along the air-mass boundaries. These high- and low-pressure cells may be short lived (hours or days) or may persist for a week or more. The precipitation and temperature characteristics within the westerlies are typically seasonal, and related to the proximity of the tropical or the polar air masses. The southern edge of the Polar Lows, along the boundary with the westerlies, is commonly called the polar front and is the area where the polar jet stream resides. The polar jet stream acts as a steering current for westerly storms. Similarly, the northern edge of the Subtropical Highs may be referred to as the subtropical front and is the location of the subtropical jet stream.

Regional climate in the conterminous United States is a result of the seasonal expansion and contraction of the tropical and polar air masses. In southerly areas of the U.S., tropical air masses and warm westerlies dominate the annual climate, whereas in northerly areas climate is dominated by polar air masses.

The general climate characteristics associated with the global air masses are often modified by regional features such as topography, large lakes, and the oceans. The Sierra Nevada Mountains and the Transverse Range have exerted significant control over past Yucca Mountain climate, continuing to the present day. Fundamentally, these mountain ranges cut the Yucca Mountain region off from its major moisture source, the Pacific Ocean, and especially from the subtropical Pacific Ocean. By creating and sustaining a major rain shadow in the Yucca Mountain region, the mountain ranges also have amplified the evaporative action of the Subtropical Highs during present-day and past interglacial climates.

Today in the Yucca Mountain region, from late spring through early fall, climate is dominated by the northward movement and intensification of the Subtropical Highs. Present-day subtropical high activity, in the Yucca Mountain region, does not, however, intensify to the point of creating a strong monsoonal weather pattern, as happens in southern Arizona and New Mexico and in Mexico. Rather, the subtropical high activity commonly produces convective thunderstorms, typically of only local importance, and intense evaporation, which is enhanced by the mountains to the west and southwest.

During late fall through early spring, the Subtropical Highs weaken and retreat south, leaving the region largely under the influence of the westerlies, whose moisture potential is greatly reduced by the Sierra Nevada Mountains, and to a lesser extent by the Transverse Range. Polar Low and occasionally Arctic High pressure may intrude into the area, resulting in wetter and less 
evaporative conditions. The wettest winters are often associated with the El Nino years, when the polar front moves south over the Pacific Ocean, steering subtropical moisture into the Yucca Mountain region. El Nino years are also high precipitation years ["The Relative Contributions of Summer and Cool-Season Precipitation to Groundwater Recharge, Spring Mountains, Nevada, USA" (Winograd et al. 1998 [DIRS 109466])], but the El Nino circulation is usually not sustained, and the Subtropical Highs return decreasing precipitation and increasing evapotranspiration in the region. This Subtropical-High-dominated climate regime has dominated regional climate for about the past 9,000 to 10,000 years, with some episodes being hotter and drier, and others being cooler and wetter, than present-day [The Climatic and Hydrologic History of Southern Nevada During the Late Quaternary (Forester et al. 1999 [DIRS 109425], Figure 14)].

The present-day interglacial climate, and that of the past 8,000 years or so, is not typical of climate during the last several hundred thousand years. Past climates have included glacial periods, and a variety of climates intermediate between glacial and interglacial, all of which may be simplistically thought of in terms of dominance of the polar and tropical air masses. The expansion of continental ice into the United States means that the polar air masses expanded and became persistent in more southerly areas throughout the year; otherwise, the continental ice and snow would have melted. Because the basic physical laws of atmospheric circulation are conserved, when the polar air masses expand and become more persistent, the Polar Lows must also move southward, both in the sense of the seasonal extreme and their average position. As the Polar Lows expand southward, the wet, cool "boreal" realm moves southward, resulting in wetter and cooler conditions in places that today are warmer and drier. Local topography and air-mass dynamics will modify the polar low climate, such that, for example, the very wet northwest United States climates are not literally transposed southward.

In the Yucca Mountain region a glacial climate would mean longer winter seasons and shorter summer seasons. Subtropical Highs would be less persistent, so mean annual temperature (MAT), summer temperature, and the high summer evaporation would be lower, resulting in the potential for more infiltration, even if mean annual precipitation (MAP) remained constant. MAP, however, won't remain constant, because there would be more frequent and persistent incursions of polar-low activity, bringing more rain and snow during glacial periods than today. Infiltration is further increased during these periods, because winter precipitation, as melting snow, would be less likely to evaporate or be used by the vegetation, so evapotranspiration would be much lower. During some glacial periods, when large continental ice sheets existed, Arctic Highs were likely resident in the Yucca Mountain region for much or perhaps all of the year, resulting in very cold and dry conditions, with limited evaporation ["Relict Colluvial Boulder Deposits as Paleoclimatic Indicators in the Yucca Mountain Region, Southern Nevada" (Whitney and Harrington 1993 [DIRS 107303]); Quantitative Paleoclimatic Reconstructions from Late Pleistocene Plant Macrofossils of the Yucca Mountain Region (Thompson et al. 1999 [DIRS 109470])]. Relative to present-day climate, infiltration would be higher during these cold, dry climates, because evaporation would be lower.

There were also interglacial periods in the Yucca Mountain region that appear to have been warmer and wetter than the "typical" interglacial period (Forester et al. 1999 [DIRS 109425]). During these periods, the Subtropical Highs would have expanded and/or intensified, resulting in a northward shift of the southwestern monsoon. Summer precipitation probably increased 
dramatically, resulting in higher MAP, but because this was summer precipitation, much of it likely was lost to evapotranspiration, due to higher air temperatures, and active transpiration by the vegetation community. Conversely, there also were times during glacial-transition climates when the climate was wetter than during some glacial periods and cooler than the interglacial period (but not extremely cold), potentially enhancing infiltration.

On time scales of hundreds of thousands of years, climate change is large, and hence change in climate parameters affecting infiltration also is large. The largest amounts of infiltration probably occurred when very large continental ice sheets existed, resulting in cold, low evaporative conditions in the Yucca Mountain region. Although the interglacial (present-daylike) climates only persisted for about twenty percent of the documented interglacial/glacial history [(Forester et al. 1999 [DIRS 109425]; "Duration and Structure of the Past Four Interglaciations" (Winograd et al. 1997 [DIRS 100096])], the times when very large ice sheets existed also were limited, so much of the Yucca Mountain climate history is dominated by intermediate climates. For example, the full ice-maximum of the last glacial period, around 21,000 years ago, lasted only a couple of thousand years. By contrast, the penultimate glacial period from about 140,000 to 175,000 years ago may have sustained a large ice sheet for as much as 35,000 years, with cold, low-evaporative, and possibly wet conditions in the Yucca Mountain region. The importance of the penultimate glacial in the Yucca Mountain region is shown by the existence at that time of a large, 175-m-deep lake in Death Valley ["U-Series Chronology of Lacustrine Deposits in Death Valley, California" (Ku et al. 1998 [DIRS 109438])], now one of the driest areas in the United States. Other glacial climates, for example those about 300,000 to 400,000 years ago, were cool and wet, rather than cold and either dry or wet, in the Yucca Mountain region. Each glacial and interglacial period appears to have a characteristic climate with unique infiltration characteristics. The nature of all climate change can be simplified as a seasonal interplay of the polar, tropical, and westerly air masses.

\subsection{THE CYCLICAL NATURE OF CLIMATE CHANGE-DEVILS HOLE}

The first assumption for this analysis is that climate is cyclical, and thus the past can be used to forecast the future. That is, if climate change exhibits some rhythmic pattern, then future climates will repeat, or at least approximate, past climates. For this particular assumption, that is that climate is cyclical, the only issue is whether or not the present-day interglacial period will be followed by a climate change toward glacial and then eventually into a glacial climate. Past climate cycles are a series of glacial/interglacial couplets. To illustrate the cyclic nature of past climate, the delta oxygen-18 $\left(\delta^{18} \mathrm{O}\right)$ isotope record from a calcite core at Devils Hole, Nevada, about 90 kilometers $(\mathrm{km})$ south of Yucca Mountain (Figure 6-1), provides the best information about climate change in the region (Landwehr et al. 1997 [DIRS 109124]). Stable isotope compositions are typically reported in delta $(\delta)$ notation as the per mil deviation of the ratio of the heavy to light isotopes $\left({ }^{18} \mathrm{O} /{ }^{16} \mathrm{O}\right.$ ) in the sample to that of a reporting standard (Vienna Standard Mean Ocean Water for ${ }^{18} \mathrm{O} /{ }^{16} \mathrm{O}$ ).

Devils Hole is an active extensional fracture in the Paleozoic limestone that composes the regional Paleozoic aquifer. During the last 500,000 or more years calcite has precipitated on the walls of the fracture, leaving an isotopic record of the regional groundwater flowing through the fracture (Winograd et al. 1992 [DIRS 100094]). The calcite has been cored, and the core has been extensively dated ["Mass-Spectrometric ${ }^{230} \mathrm{Th}-{ }^{234} \mathrm{U}-{ }^{238} \mathrm{U}$ Dating of the Devils Hole Calcite 
Vein" (Ludwig et al. 1992 [DIRS 104631])]. The $\delta^{18} \mathrm{O}$ data (Landwehr et al. 1997 [DIRS 109124], DTN: GS000200005121.003 [DIRS 146819]) from one core show an irregular cyclicity between high and low values for the last 425,000 years (Figure 6-3).

The $\delta^{18} \mathrm{O}$ isotopic composition of groundwater flowing through the Devils Hole fracture (Figure 6-3) (Landwehr et al. 1997 [DIRS 109124]) records the isotopic composition of infiltration in the recharge area of the regional aquifer (Winograd et al. 1992 [DIRS 100094]). The isotopic values of infiltration are related to three factors: (1) the isotopic composition and temperature of the source water, the tropical and subtropical Pacific Ocean; (2) the path that the water vapor takes from the source to the recharge area, and the amount of precipitation that occurs along the path; and (3) the temperature at which the precipitation in the recharge area forms.

When water evaporates from source water, the degree of fractionation (under equilibrium conditions) depends on the temperature of the source: the colder the source, the greater the fractionation (Kim and O'Neil 1997 [DIRS 106367]). The resulting vapor has a $\delta^{18} \mathrm{O}$ value that is equal to the source minus the fractionation factor, so the vapor has a lower value than the source water. Equilibrium conditions often do not exist in the source areas, resulting in vapor values that are even lower than those that result from equilibrium conditions (Grootes 1993 [DIRS 109429]). Some of the ocean-derived vapor moves over the continent forming precipitation as snow or rain and, over time, that precipitation returns to the ocean, completing the hydrological cycle. During glacial periods, however, a significant amount of the precipitation is stored as snow and ice, and thus does not return to the ocean. Consequently, the isotope value of the ocean becomes higher during glacial periods. The cycle in $\delta^{18} \mathrm{O}$ values in marine carbonates between low and high values records the storage or loss of continental ice, and hence glacial or interglacial climates. There may be a corresponding change in the isotope values of precipitation in the Devils Hole recharge area, reflecting changes in the isotope values of the source areas; however, a source area signature, because it would be small relative to the path effects, is not evident in the Devils Hole $\delta^{18} \mathrm{O}$ record (Landwehr et al. 1997 [DIRS 109124], DTN: GS000200005121.003 [DIRS 146819]).

The path and conditions along the path taken by vapor as it moves from the source area toward the recharge area have an important effect on the $\delta^{18} \mathrm{O}$ values of precipitation in the recharge area. As vapor is chilled, whether from rising through the atmosphere due to thermal expansion or over topography or due to mixing with cooler air, some vapor turns to rain or snow. The fractionation as vapor turns to precipitation reverses that of evaporation, so precipitation has a higher $\delta^{18} \mathrm{O}$ value than its vapor source. Following each precipitation event, the remaining vapor has an ever-lower value. If the path to the recharge area involves extensive precipitation, then the precipitation in the recharge area will have low $\delta^{18} \mathrm{O}$ values, and if the vapor path does not involve extensive precipitation, then the precipitation in the recharge area will have relatively high values. Typically, interglacial precipitation has higher $\delta^{18} \mathrm{O}$ values than glacial precipitation because the glacial path involves more precipitation, so in the carbonate $\delta^{18} \mathrm{O}$ record from Devils Hole (Landwehr et al. 1997 [DIRS 109124], DTN: GS000200005121.003 [DIRS 146819]), high values represent interglacial climates, and low values represent glacial or glacial-transition values (the opposite of the ocean). 

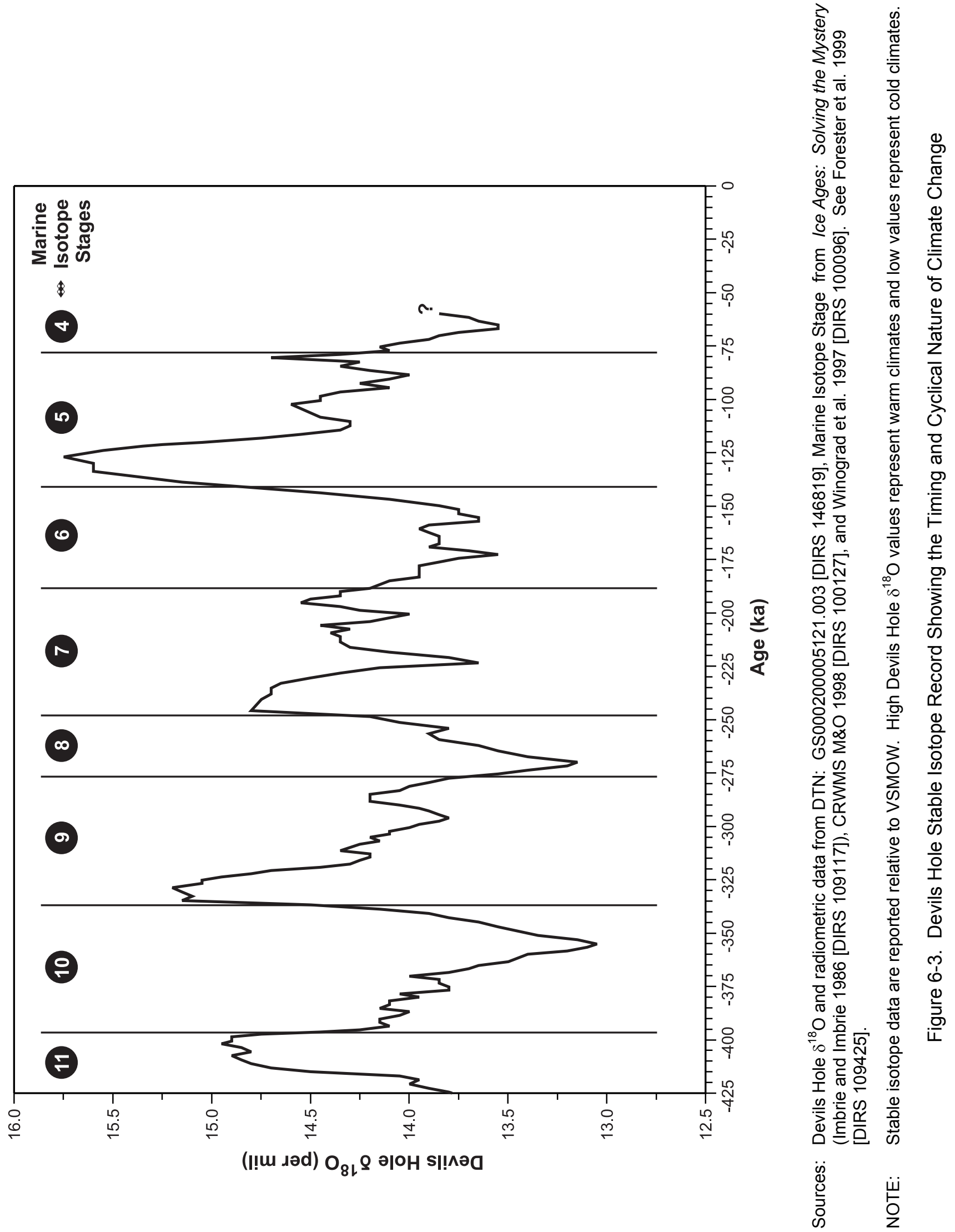
Finally, because fractionation between vapor and precipitation is temperature dependent, the $\delta^{18} \mathrm{O}$ values of precipitation from very cold snow should be higher than those of warm snow and those of warm snow should be higher than those of rain. Thus, if all other factors along the vapor path were constant, a very cold glacial period would have higher $\delta^{18} \mathrm{O}$ infiltration values, which are close to precipitation values, than a warm glacial period. Because all other factors are not constant, recognition of temperature differences for precipitation in the recharge area between different glacial climates may be difficult.

The cycles in the $\delta^{18} \mathrm{O}$ data from Devils Hole for the past 425,000 years (Landwehr et al. 1997 [DIRS 109124], DTN: GS000200005121.003 [DIRS 146819]) reflect a cyclic change from interglacial to glacial climates, each of which can be identified by a number (Figure 6-3) for a marine isotope stage (OIS), where odd numbers are interglacials and even numbers are glacials. The OISs are derived from the marine carbonate $\delta^{18} \mathrm{O}$ records that reflect changes in $\delta^{18} \mathrm{O}$ values of ocean water as continental ice sheets expand and contract (CRWMS M\&O 1998 [DIRS 100127], pp. 4.2-9 to 4.2-12; Shackleton and Opdyke 1973 [DIRS 109163]). The OIS and Devils Hole chronologies are not correlated exactly, and, in particular, differ in the timing of the glacial terminations (Winograd et al. 1992 [DIRS 100094]). The Devils Hole chronology is assumed to be most appropriate for the Yucca Mountain region and is used in this report.

The Devils Hole $\delta^{18} \mathrm{O}$ record (Landwehr et al. 1997 [DIRS 109124], DTN: GS000200005121.003 [DIRS 146819]), as interpreted in terms of changes in isotopic values of infiltration in the recharge area, shows that climate is cyclic on a millennial time scale. The cycles, however, differ in duration (Winograd et al. 1992 [DIRS 100094]; Ludwig et al. 1992 [DIRS 104631]; Winograd et al. 1997 [DIRS 100096]).

\subsection{TIMING OF PAST-CLIMATE CHANGE AND EARTH-ORBITAL PARAMETERS}

The second key assumption in this analysis is that the timing of past climate change provides a rationale for timing future climate change. Timing future climate change requires that such change be based on parameters whose future values can be accurately calculated. According to the Milankovitch Theory, earth-orbital parameters, whose past and future values are readily calculated from basic celestial mechanics, provide the necessary values, if and only if a relation exists between the timing of climate change and those parameters (Imbrie and Imbrie 1986 [DIRS 109117]). Using identifiable relations between orbital parameters and the timing of past climate change to forecast future climate change is acknowledged by the NRC (NRC 1997 [DIRS 100408]). Because the causes of past change from interglacial to glacial and back to interglacial climates remain unknown, using the timing of past climate change as a basis for the future timing of climate change should be viewed with caution.

There are three orbital parameters, each having its own periodicity: 1) eccentricity, the shape of the earth's orbit changing in a systematic way from an ellipse to circular and back to an ellipse with time, about every 100,000 years; 2) obliquity, the angle of the earth's axis of rotation changing a few degrees with time, about every 41,000 years; and 3) precession, the wobble of the earth's axis like that of a spinning top changing with time, about every 23,000 years. Precession, which dominates insolation (heat from the sun as measured at the top of the atmosphere) at low latitudes, is the primary parameter used here to identify the timing of climate 
change (Figures 6-4 and 6-5). Because of precession the summer of perihelion (the point in the orbit nearest the sun) shifts from one hemisphere to the other about every 11,500 years or so. Figure 6-5 shows how eccentricity amplifies or dampens the precession value. Obliquity, which influences the nature of seasonality at high latitudes and is a key component in SPECMAP, did not show any consistent relation with the Devils Hole record (Landwehr et al. 1997 [DIRS 109124], DTN: GS000200005121.003 [DIRS 146819]), so it is not considered further. SPECMAP is a spectral coordinate map of climate time series of the past 400,000 years derived for 17 sediment cores from the Atlantic Ocean that is a widely accepted benchmark for the field of paleoclimitology (Imbrie and Imbrie 1986 [DIRS 109117]).

Milankovitch theory or Milonkovitch forcing refers to the theory of orbital forcing presented in Figure 6-4 and has substantial empirical support (Crowley 2002 [DIRS 160151]). While the correspondence between Milankovitch Theory and the ${ }^{18} \mathrm{O}$ data record from Devils Hole has been debated, there is evidence that a reasonable match between the phase changes in the Devils Hole data and variations in earth's precession and obliquity exists (Imbrie et al. 1993 [DIRS 109118]). The following discussion introduces orbital forcing according to Milankovitch Theory including precession, obliquity, and eccentricity. This discussion refers to the second assumption in Section 5, that the timing of long-term past climate change and the timing of earth-orbital changes are related. Although the physical mechanisms involved in mineral formation at Devils Hole are quite different than climatic forcing by earth-orbital change, the correlation between the two records provides additional evidence to support assumption 2 .

Under Milankovitch Theory insolation is calculated from known principles of celestial mechanics so that future values of insolation may be determined. The Earth presently falls within the eccentric 400,000-year cycle where during the next 100,000-year sub-cycle the Earth orbit will experience a relatively circular rather than elliptical orbit. The last time that occurred was 400,000 years ago and insolation for the next 100,000 years would be expected to be similar to that between 400,000 and 300,000 years ago (Forester et al. 1999 [DIRS 109425]). These celestial mechanics involved in Milankovitch forcing justify the 400,000-year cycle discussed in this report.

Recognition of relations between climate change and orbital parameters demands a well-dated, long, earth-based climate record, a record with a very accurate internal chronology. A good earth-based climate chronology allows for confident comparison of the timing of change between the climate and the orbital parameters. The timing of orbital parameters is derived from basic celestial mechanics, and is discussed in "Insolation Values for the Climate of the Last 10 Million Years" (Berger and Loutre 1991 [DIRS 108910]), whose values are used in this discussion (Figures 6-4 and 6-5). The time under consideration is the past 400,000 years, because that interval of time is about equivalent to the long earth-orbital cycle, also known as a long eccentricity cycle. The long eccentricity cycles are not exactly 400,000 years in duration (Figure 6-5). For example, the time between the high value of eccentricity just before 400,000 years ago and the high value before 0 years is about 391,000 years. The exact time between the corresponding eccentricity values of earlier cycles is not constant, but for simplicity of discussion all will be referred to herein as 400,000-year cycles. "On the Structure and Origin of Major Glaciation Cycles, 1. Linear Responses to Milankovitch Forcing” (Imbrie et al. 1992 [DIRS 109430]) and "On the Structure and Origin of Major Glaciation Cycles, 2. The 100,000-Year Cycle" (Imbrie et al. 1993 [DIRS 109432]) provide a discussion of the perceived 
relation between orbital dynamics and climate change (SPECMAP, CRWMS M\&O 1998 [DIRS 100127], p. 4.2 10). Winograd et al. (1992 [DIRS 100094]) have challenged the linkage between orbital forcing of climate change based on the difference between timing of climate change in the Devils Hole record (Landwehr et al. 1997 [DIRS 109124]; DTN: GS000200005121.003 [DIRS 146819]) and the SPECMAP chronology (CRWMS M\&O 1998 [DIRS 100127], p. 4.2-14). However, that is not at issue here, because the Devils Hole chronology of climate change is used in this analysis.

The orbital cycles (Berger and Loutre 1991 [DIRS 108910], DTN: GS000200005121.001 [DIRS 146818]) are compared with the Devils Hole climate change chronology (Landwehr et al. 1997 [DIRS 109124], DTN: GS000200005121.003 [DIRS 146819]) because Devils Hole is the only accurately and independently dated climate record on earth. Other long, dated climate records exist, but typically the chronology for those records relies on extensive interpolation between dates. Therefore, in this analysis, the Devils Hole record forms the basis for the comparison and timing of climate change. The temporal changes in the orbital parameters are compared with the Devils Hole climate change chronology in search of an orbital clock that agrees with the times for climate change at Devils Hole and from that can be used to time future climate change. The latter is the opposite of common practice in which climate records acquire their chronology from orbital data, and that is because all earth records except Devils Hole lack a continuous internal chronology.

A general qualitative relation between Devils Hole data (Landwehr et al. 1997 [DIRS 109124]; DTN: GS000200005121.003 [DIRS 146819]) and precession (Berger and Loutre 1991 [DIRS 108910]; DTN: GS000200005121.001 [DIRS 146818]) is evident where maximal values of precession mark the ends of the Devils Hole interglacials and other warm periods (Figure 6-6). That qualitative relation was expanded into a formal relation between the Devils Hole $\delta^{18} \mathrm{O}$ profile, precession, and eccentricity from direct inspection of the respective curves. The formal relation provides an orbital clock that offers a rationale for timing future climate change in terms of the Devils Hole chronology of climate change in the Yucca Mountain region. Imbrie et al. (1993 [DIRS 109118]) and Shaffer et al. (1996 [DIRS 109164]) also have identified similarities between the Devils Hole $\delta^{18} \mathrm{O}$ profile and orbital parameters. In the latter two studies, Devils Hole data were compared to orbital parameters (the opposite of what was done in this study) to determine whether the Devils Hole record reflects orbital forcing. 


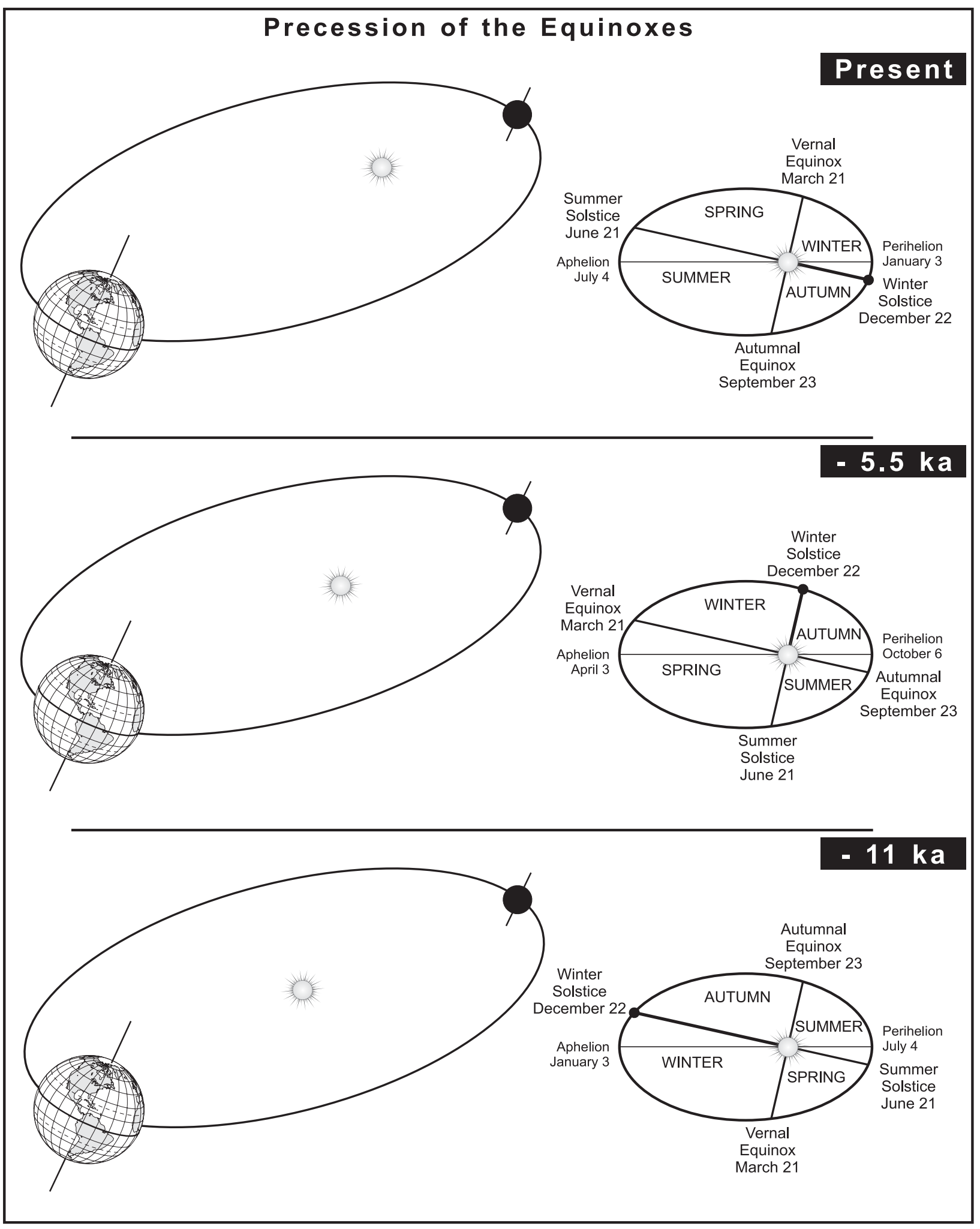

Source: Modified from Imbrie and Imbrie (1986 [DIRS 109117], Figures. 13, 14, 16).

Figure 6-4. Generalized View of Precession, an Orbital Parameter Related to the Timing of Earth's Long-Term Climate Change 


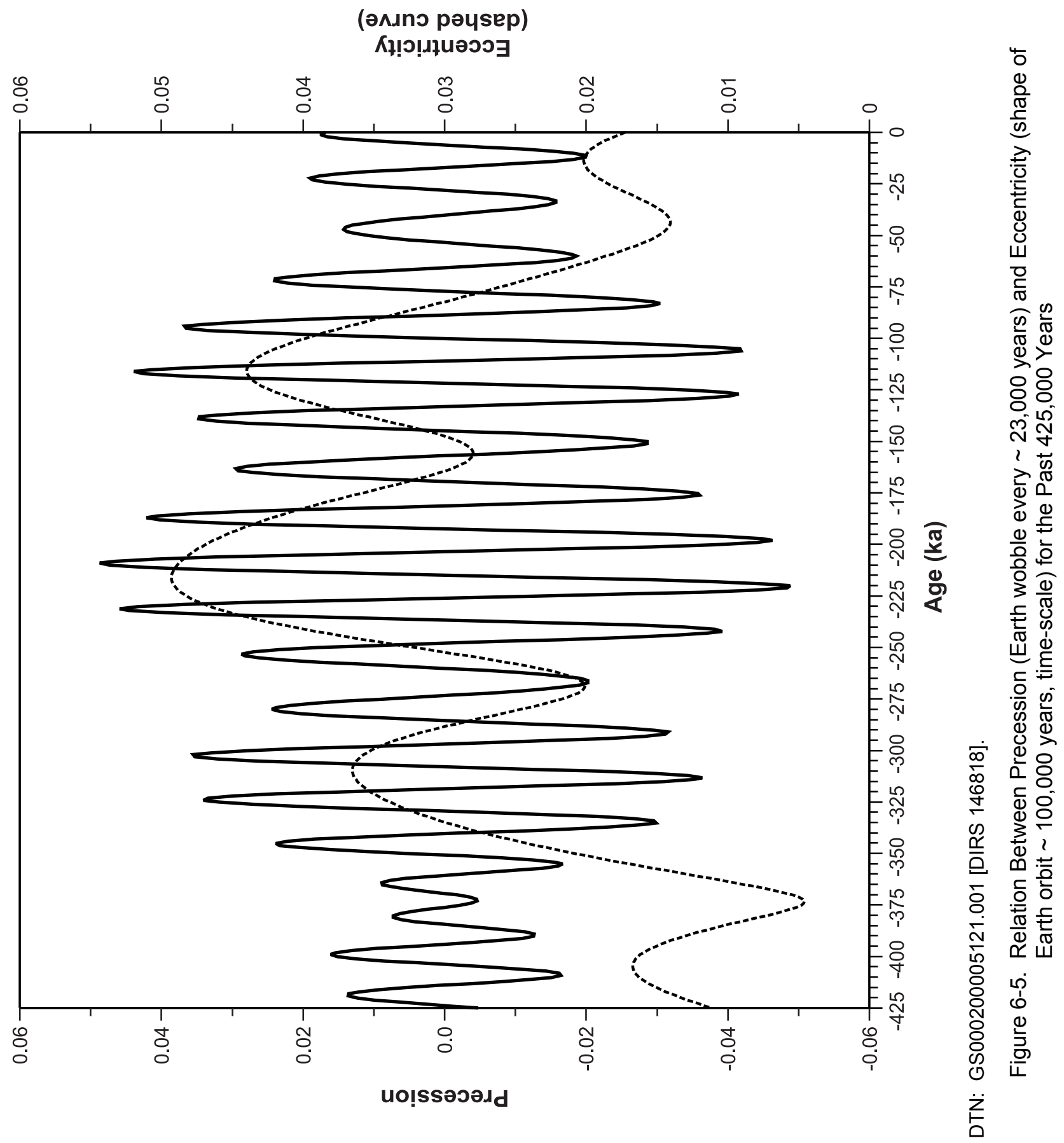




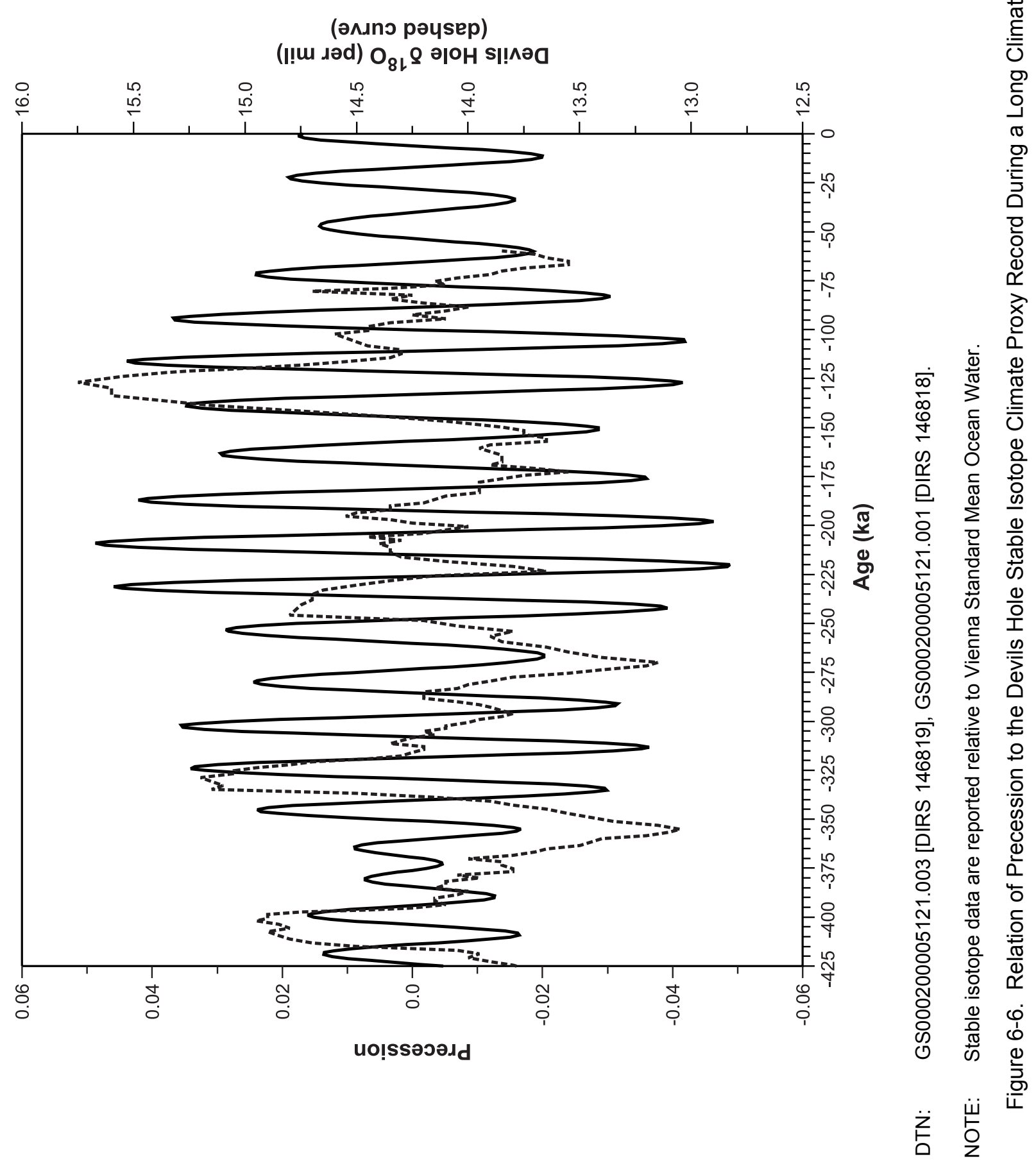


There are other lesser factors that may influence climate with the potential to obscure relationships between climate change and orbital parameters. Change in orbital parameters may simply be correlated with some other factor that causes climate change, such as solar output ["Unified Structure in Quaternary Climate" (Gauthier 1999 [DIRS 109427])], or may be a relatively minor factor, but one that tips the balance and drives the earth's climate system over some unknown threshold (Shaffer et al. 1996 [DIRS 109164]). Although the relationship between timing of past climate change and earth-orbital parameters provides information about the timing of climate change, it also does not imply magnitude or nature of that climate change.

In order to describe the formal relation for orbital timing of climate change, the relation between Devils Hole $\delta^{18} \mathrm{O}$ (Landwehr et al. 1997 [DIRS 109124], DTN: GS000200005121.003 [DIRS 146819]) and precession (Berger and Loutre 1991 [DIRS 108910], DTN: GS000200005121.001 [DIRS 146818]) shown in Figure 6-6 was examined. Notice that the inflection points in the Devils Hole data marking a change from a high toward a low value coming forward in time correspond to high precession values. Precession plays the dominant role in determining the nature of tropical and subtropical insolation, so a relation between the precession spectra and the Devils Hole record may imply a linkage between climate change and tropical insolation.

By comparing the Devils Hole $\delta^{18} \mathrm{O}$ and age data (Landwehr et al. 1997 [DIRS 109124], DTN: GS000200005121.003 [DIRS 146819]) with orbital parameter and age data (Berger and Loutre 1991 [DIRS 108910], DTN: GS000200005121.001 [DIRS 146818]), a formal relation was found to determine which precession values are the ones that define the beginning or the end of a glacial period, so the relation could be applied in a consistent way to the orbital-parameter data in the future. The relation, starting with the end of the interglacial period around 400,000 years ago, appears to consistently identify all of the primary inflection points in the available Devils Hole record (new work at Devils Hole has extended the record from about 50,000 to about 9,000 years ago, but those data are not yet available).

Inspection of precession plots (Figures 6-7 and 6-8) and of the timing of precession versus Devils Hole $\delta^{18} \mathrm{O}$ (Figure 6-6) shows that, in particular, a maximal positive precession (letter I in Figures 6-7, 6-8, and 6-9) marks the approximate termination for all of the interglacials defined by the Devils Hole record. By convention, a maximal positive precession is maximum precession (see Figures 6-4 and 6-5) in the Southern Hemisphere, whereas a minimal (most) negative value is maximum precession in the Northern Hemisphere.

Termination of interglacials is defined here as the point in time where the Devils Hole $\delta^{18} \mathrm{O}$ curve (Landwehr et al. 1997 [DIRS 109124], DTN: GS000200005121.003 [DIRS 146819]) moves from high interglacial values toward lower values, that is, the terminal inflection point in an interglacial sequence coming forward in time, identified by the number below the letter I in Figure 6-9. It is less evident, but will be suggested below, that minimal precession values mark the ends of glacial periods, which are here defined as the point in time where the Devils Hole $\delta^{18} \mathrm{O}$ record reverses its trend from low values and moves progressively toward high values, that is, the primary inflection point in the curve beyond which the values become progressively higher, identified by the number near the letter $T$ in Figure 6-9. Selecting inflection points at the ends of interglacials and glacial periods to mark the beginnings and ends of (inter)glacial periods is not conventional, but better suits the purposes of this study. 


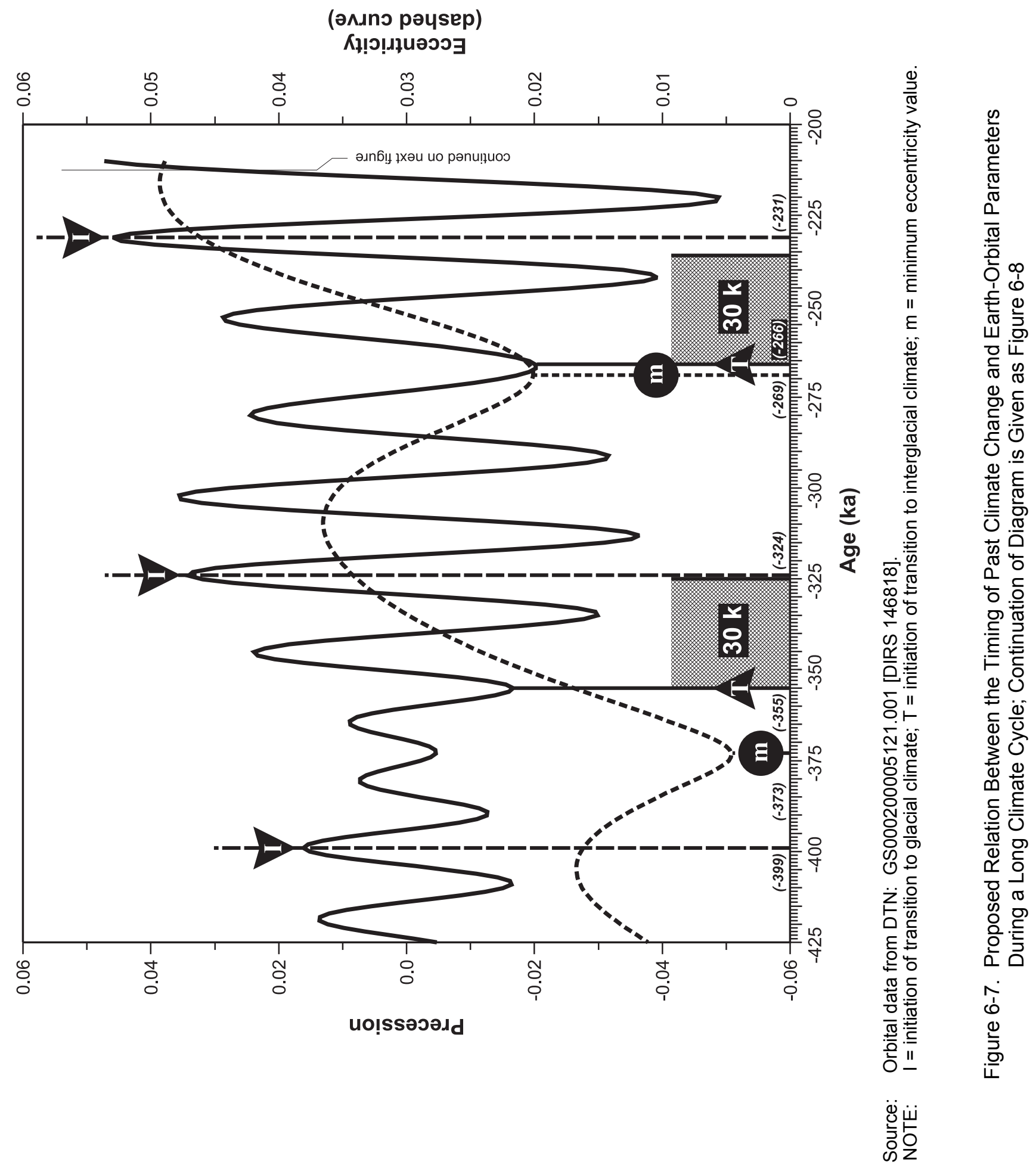




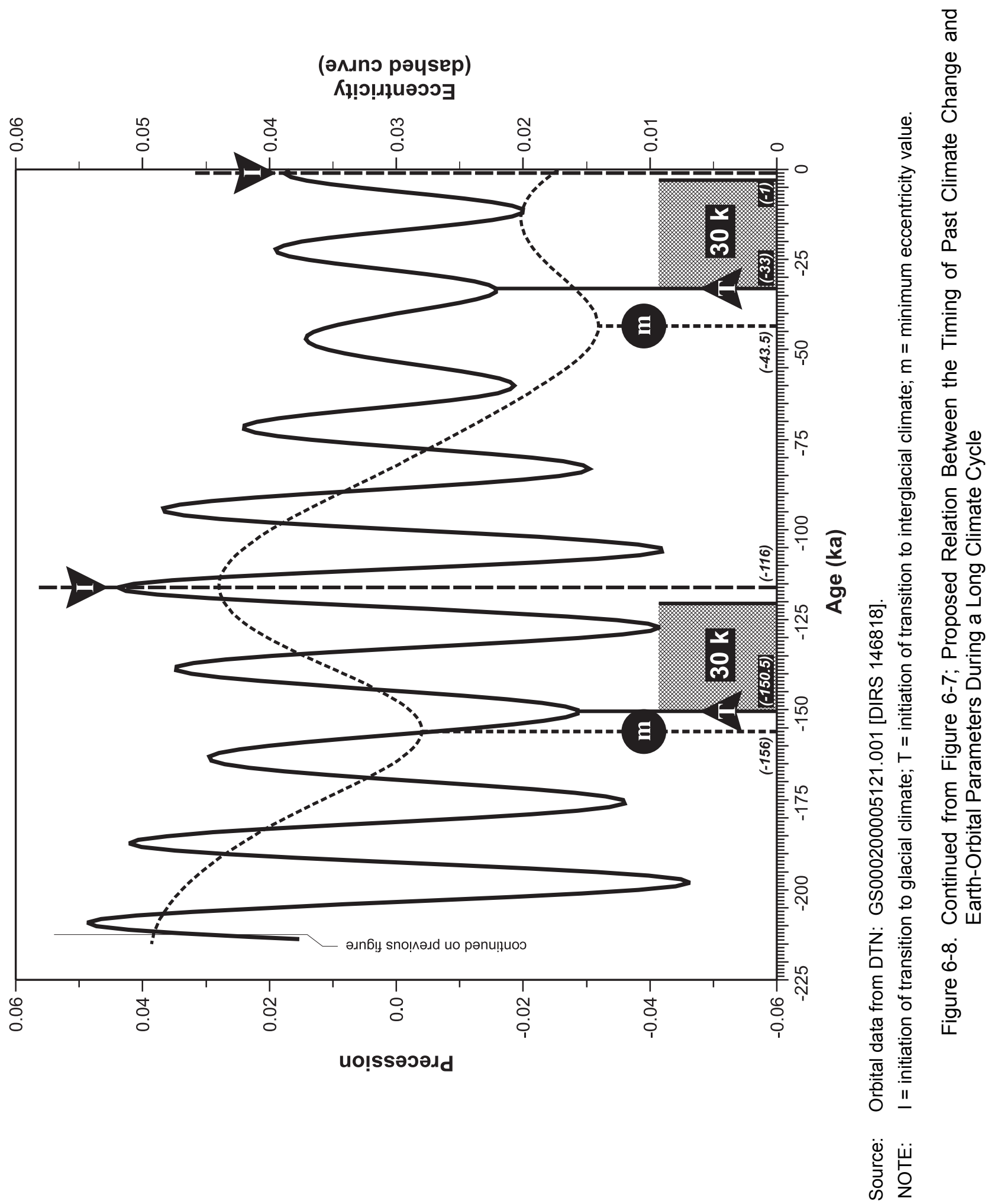


Final glacial inflection points (Figure 6-9), marking the point after which the Devils Hole $\delta^{18} \mathrm{O}$ values become progressively higher (Landwehr et al. 1997 [DIRS 109124], DTN: GS000200005121.003 [DIRS 146819]), are defined by the first minimal (Northern Hemisphere precession maximal) precession value (letter $\mathrm{T}$ in Figures 6-7 and 6-8) (Berger and Loutre 1991 [DIRS 108910], DTN: GS000200005121.001 [DIRS 146818]) following an eccentricity minimum value (letter $\mathrm{m}$ in Figures 6-7 and 6-8). If a precession minimum coincides with an eccentricity minimum, which happens with the first glacial period in the 400,000-year cycle, then the next precession minimum marks the final glacial inflection point. The next (younger) interglacial inflection point, that is the inflection point in the Devils Hole record after which the $\delta^{18} \mathrm{O}$ values become progressively lower, occurs at the first precession maximal value about 30,000 years after the preceding precessional minimum (Figures 6-7 and 6-8). The 30,000-year value is a constant that was found to work for the entire 400,000-year sequence and has no other special significance.

The general nature of (inter)glacial climate probably does not change at the primary inflection points, but rather change toward an (inter)glacial climate begins at that point. And, climate does not necessarily move continuously toward an (inter)glacial state. The Devils Hole $\delta^{18} \mathrm{O}$ profile (Landwehr et al. 1997 [DIRS 109124], DTN: GS000200005121.003 [DIRS 146819]) is a relatively smooth curve indicating a continuous transition toward and into (inter)glacial climates, but the Devils Hole data points integrate about 1,000 years or so (Winograd et al. 1992 [DIRS 100094]). Examination of a higher resolution curve such as the deuterium record of the last 420,000 years from Antarctica ["Climate and Atmospheric History of the Past 420,000 Years from the Vostok Ice Core, Antarctica" (Petit et al. 1999 [DIRS 109450])] shows a pattern of numerous small magnitude climate reversals that occur on decade and century time scales. In fact, the Devils Hole $\delta^{18} \mathrm{O}$ record shows a reversal at about 220,000 years ago that is seemingly small in magnitude and only persists for a couple of thousand years. Therefore, these "primary" inflection points in the Devils Hole record identified with the precession methodology should not be thought of as absolute timings of climate change because climate reversals toward (inter)glacials may well occur following the inflection point.

The timing of (inter)glacial bounding precession maximal and minimal values (Berger and Loutre 1991 [DIRS 108910], DTN: GS000200005121.001 [DIRS 146818]) are shown on the Devils Hole $\delta^{18} \mathrm{O}$ curve (Figure 6-9) (Landwehr et al. 1997 [DIRS 109124], DTN: GS000200005121.003 [DIRS 146819]). The correspondence between the precession-based and Devils Hole-based sets of values is nearly identical in most cases and off by 10,700 years in one case. Although the primary inflection points signal the beginning of change to the next climate state, there is a substantial amount of time following each primary inflection point until the next climate state is reached. For example, an interglacial climate, as defined by the Devils Hole $\delta^{18} \mathrm{O}$ values reaching a plateau following a glacial period, takes from about 20,000 to 25,000 years after the glacial primary inflection point. 


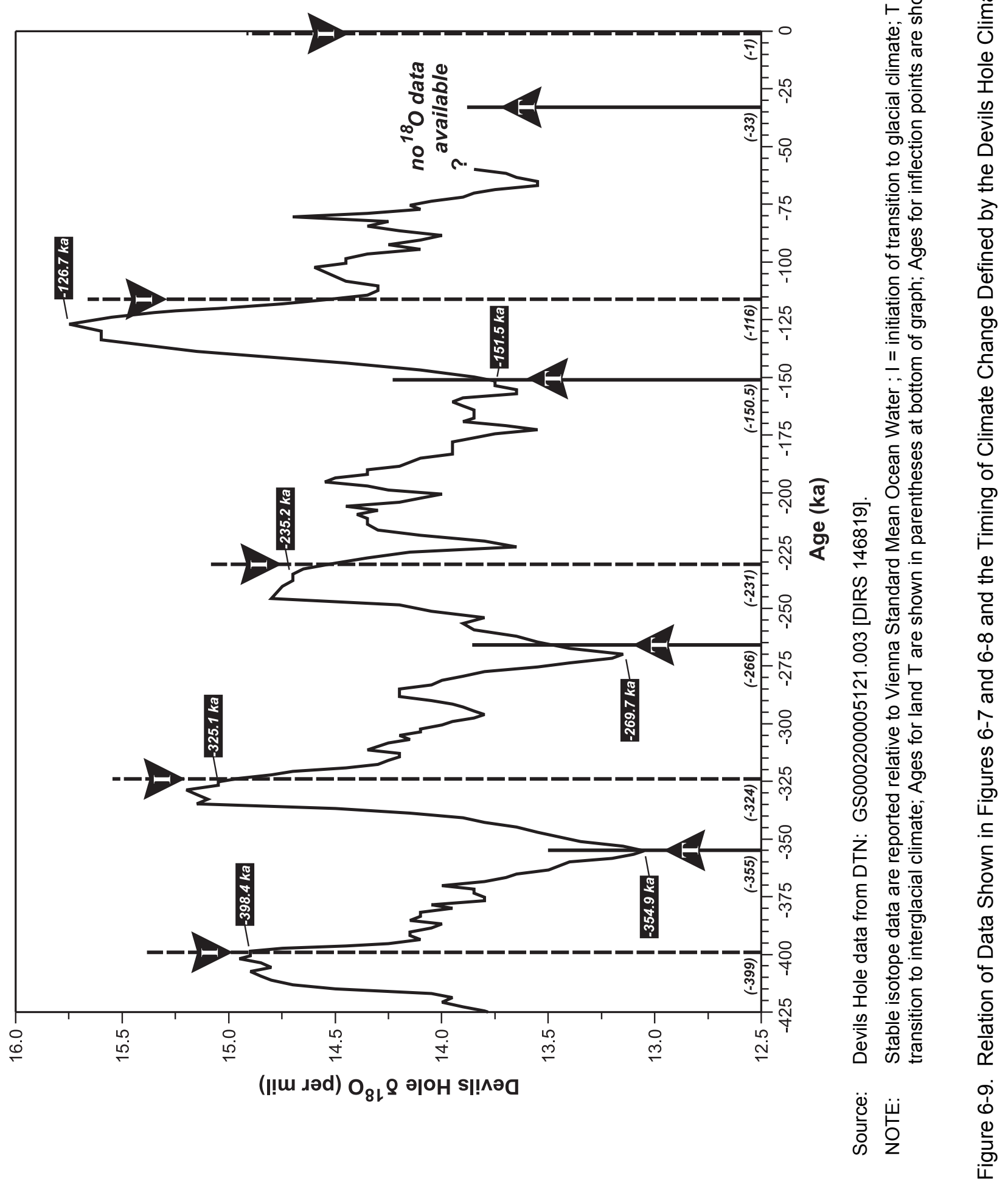


The differences between the timing of the precession-based ages (Berger and Loutre 1991 [DIRS 108910], DTN: GS000200005121.001 [DIRS 146818]) and the ages of the Devils Hole $\delta^{18} \mathrm{O}$ inflection points (Landwehr et al. 1997 [DIRS 109124], DTN: GS000200005121.003 [DIRS 146819]) could be caused by several factors. The differences may reflect the age uncertainty in the Devils Hole dates, even though that uncertainty is usually small. The difference could be due to the methodology of selecting a precession value that marks the Devils Hole $\delta^{18} \mathrm{O}$ inflection points, if precession values represent a fortuitous correlation with climate change. Or the differences could be a function of regional climate, where a Devils Hole primary inflection point precedes or follows global change.

The largest discrepancy between the Devils Hole $\delta^{18} \mathrm{O}$ record (Landwehr et al. 1997 [DIRS 109124], DTN: GS000200005121.003 [DIRS 146819]) and precession (Berger and Loutre 1991 [DIRS 108910], DTN: GS000200005121.001 [DIRS 146818]) occurs at the end of interglacial stage 5e, which at Devils Hole is 126,700 years ago (Figure 6-9). The penultimate interglacial, stage 5e, was warmer than the present interglacial, as sea level was higher than today ["New Uranium-Series Ages of the Waimanalo Limestone, Oahu, Hawaii: Implications for Sea Level During the Last Interglacial Period" (Muhs and Szabo 1994 [DIRS 109446])]. The $\delta^{18} \mathrm{O}$ values from the Devils Hole record for this interglacial period are higher than for the other interglacials. As noted above, high $\delta^{18} \mathrm{O}$ values for precipitation in the recharge area imply limited rain out along the path taken by vapor from the source to the recharge area. Thus, the primary inflection point at the end of the interglacial stage $5 \mathrm{e}$ in the Devils Hole $\delta^{18} \mathrm{O}$ data may reflect a change in the vapor path, but not the actual end of that interglacial period. Szabo et al. (1994 [DIRS 109458]) place the end of interglacial stage 5e at about 114,000 years ago. The precessional timing for the end of this stage is 116,000 years ago (Figure 6-9) and thus at a similar relative age difference as observed for earlier interglacial primary inflection points. If the timing found in "Thorium-230 Ages of Corals and Duration of the Last Interglacial Sea-Level High Stand on Oahu, Hawaii" (Szabo et al. 1994 [DIRS 109458]) is used, all of the precession ages and the available Devils Hole inflection point ages are within 2,500 years or less of each other, a good agreement for the two sets of data.

The precessional method (Berger and Loutre 1991 [DIRS 108910], DTN: GS000200005121.001 [DIRS 146818]) for identifying the primary inflection points within the Devils Hole record (Landwehr et al. 1997 [DIRS 109124], DTN: GS000200005121.003 [DIRS 146819]) indicates there is a primary glacial inflection point at about 33,000 years ago, thus indicating climate change toward warmer conditions. Because the younger part of the Devils Hole record is not available, it is not known if the minimal precession value at 33,000 years ago corresponds with an inflection point in the Devils Hole record. If the Devils Hole record responds in the same manner about 33,000 years ago as it has in earlier parts of the record, then it should show an inflection point within a couple of thousand years of 33,000 years ago.

"High Resolution $\delta^{18} \mathrm{O}$ Record from Devils Hole, Nevada, for the Period 80 to 19 Ka" (Winograd et al. 1996 [DIRS 109468]) discusses the younger part of the Devils Hole record and describes a sharp warming trend beginning at about 28,000 years ago as well as other evidence for warmth in this time frame. The earlier T events in Figure 6-9 have higher $\delta^{18} \mathrm{O}$ values about 5,000 years later $(33,000$ minus 28,000 years $)$ and because higher $\delta^{18} \mathrm{O}$ values imply greater warmth, warmth at Devils Hole at 28,000 years ago is consistent with the older parts of the record. "Tropical Climate Instability: The Last Glacial Cycle from a Qinghai-Tibetan Ice Core" 
(Thompson et al. 1997 [DIRS 109460]) also presents evidence for warmth in the late 30,000-year time frame and other evidence for warmth at this time is common in the literature. Thus, as with other periods marked with a $\mathrm{T}$ in Figure 6-9, the one at 33,000 years ago appears to precede a warming period, but unlike the other $\mathrm{T}$ periods, not a continuous warming period.

Following the warm period from about 32,000 through about 25,000 years ago, there was an extensive growth and advance of a continental glacier from about 24,000 to 18,000 years ago, with ice maximum around 21,000 years ago (Thompson et al. 1997 [DIRS 109460]). The climate characteristics in the vicinity of Yucca Mountain reflect a glacial climate (Thompson et al. 1999 [DIRS 109470], Forester et al. 1999 [DIRS 109425]). In terms of the precession methodology (Berger and Loutre 1991 [DIRS 108910], DTN: GS000200005121.001 [DIRS 146818]) and its relation to the Devils Hole $\delta^{18} \mathrm{O}$ record (Landwehr et al. 1997 [DIRS 109124], DTN: GS000200005121.003 [DIRS 146819]) this represents a significant reversal in the pattern displayed in the transition periods from full-glacial climates toward the interglacial climates observed in all earlier transitions in the past 400,000-year cycle. And presumably this glaciation and its portrayal in the Devils Hole $\delta^{18} \mathrm{O}$ record are much greater than the reversal at about 220,000 years ago. By contrast the present interglacial, the Holocene, begins about 10,000 years ago, 23,000 years after the 33,000-years-ago precession maximum in the Northern Hemisphere. The latter timing is consistent with timing for the beginning of earlier interglacials following the primary glacial inflection point. Thus, the last glaciation maximum about 21,000 years ago, which is not predicted by the precession methodology, may simply be an example of a climate variation, a feature that is typical of the last glacial cycle in the long orbital cycle, or an inconsistency in the precession orbital clock methodology.

The precession methodology is applied to the next 100,000 years in Figure 6-10 (DTN: GS000200005121.002 [DIRS 146817]). The timing of possible climate change toward and away from a glacial period is the same as for the change beginning about 400,000 years ago (Figures 6-7, 6-8, and 6-9). The duration between the initiation of climate change (I) at 399,000 years ago toward a glacial, and then away ( $\mathrm{T}$ ) from the glacial is 44,000 years (Berger and Loutre 1991 [DIRS 108910], DTN: GS000200005121.001 [DIRS 146818]). In Figure 6-10, the timing from a move toward the glacial period (I at 1,000 years ago) to the move away ( $\mathrm{T}$ at 44,000 years ago) is 45,000 years. As shown in Figure 6-9, the timing for the move toward and away is much longer for the remaining three glacial periods in the 400,000-year cycle, with durations of 58,000 years, 80,500 years, and 83,000 years.

The discussion above indicates that a precession-based orbital clock, calibrated with the Devils Hole chronology, provides a basis to time climate change from the interglacials toward glacials and from glacials toward interglacial climates. This clock times the beginnings and ends of the major climate events during the last 400,000-year cycle and provides a potential clock for such events in the future. 


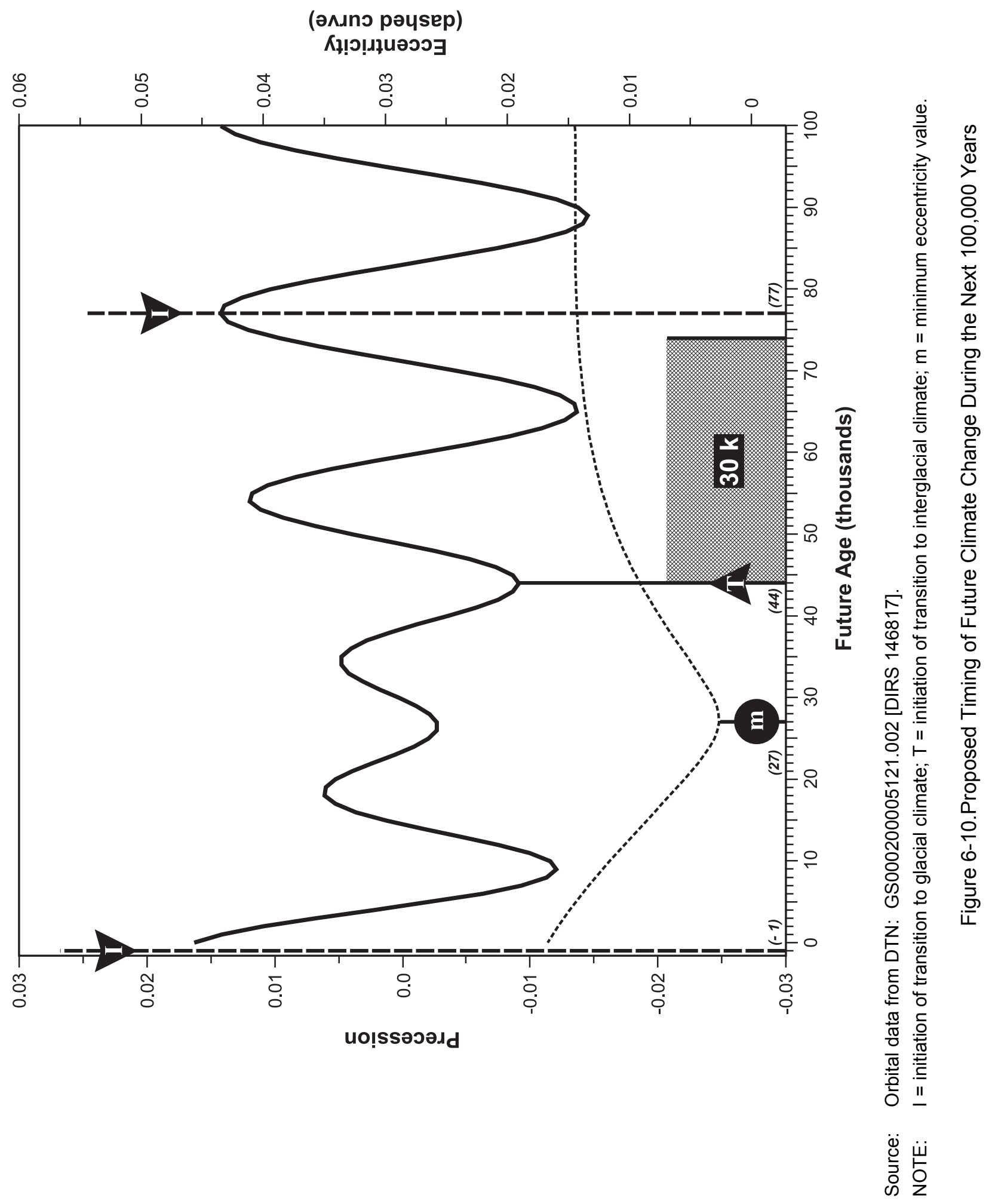


Climate change, however, does not move steadily from interglacials to glacials and back again, but instead climate change is a complex array of intermediate climates between interglacial and glacial extremes. The intermediate climates may be truly intermediate in nature or they may be warmer and wetter or drier than the interglacials and colder and wetter or drier than the glacials. Understanding the timing of intermediate climates could be important, if they were to occur in the next 10,000 years. Therefore, the question becomes do changes in precession provide insight into climate change on shorter intervals of time.

To investigate identifying and forecasting climate change for shorter intervals of time than is discussed above, Figure 6-11 shows the relation between precession (Berger and Loutre 1991 [DIRS 108910], DTN: GS000200005121.001 [DIRS 146818]) and the Devils Hole record (Landwehr et al. 1997 [DIRS 109124], DTN: GS000200005121.003 [DIRS 146819]) from 425,000 to 350,000 years ago. The rationale for the selection of this interval will be discussed in more detail below, where it will be suggested that the interval from about 399,000 years to 389,000 years ago in the Devils Hole chronology is the analog for future climate. The minor lows and highs in the Devils Hole $\delta^{18} \mathrm{O}$ data approximately, but not perfectly, correspond to the rises and falls in the precession values. This pattern is maintained for the entire Devils Hole record (Figure 6-6). Specifically, the change in precession from a maximal value to 399,000 years ago (maximum precession in the Southern Hemisphere) to a minimum value at about 390,000 years ago (maximum precession in the Northern Hemisphere) coincides with a change from a high $\delta^{18} \mathrm{O}$ value (end of the interglacial) to a lower $\delta^{18} \mathrm{O}$ value, presumably indicating a change toward a wetter and or cooler climate (Figure 6-11). The Devils Hole $\delta^{18} \mathrm{O}$ record continues to rise and fall in approximate synchroneity with precession, eventually moving to a low value at 355,000 years ago reflecting the full glacial climate. The intriguing and puzzling aspect about the correspondence between precession and the Devils Hole $\delta^{18} \mathrm{O}$ record is that in some cases there is a tendency for low values of $\delta^{18} \mathrm{O}$ to correspond with minimal precession values, which represent insolation maxima in the Northern Hemisphere summer, and so correspond with processes that, from the isotope data, indicate cooler and or wetter conditions in the recharge area. Perhaps this implies there is no causal relation between precession and the Devils Hole $\delta^{18} \mathrm{O}$ record or perhaps it means the response of the climate system follows or leads precession. Or perhaps it means maximal precession in the Northern Hemisphere, and consequently maximum summer insolation in the Northern Hemisphere, are linked somehow to the genesis of moisture necessary for the initiation of a glacial period, and if so that would seem to indicate that tropical climate drives climate change. Whether or not these or other factors are involved, these data indicate the timing of the minor inflection points in the Devils Hole record are at least approximately correlated with precession. Consequently, the timing of future subcycles in precession should also approximately time climate change. 


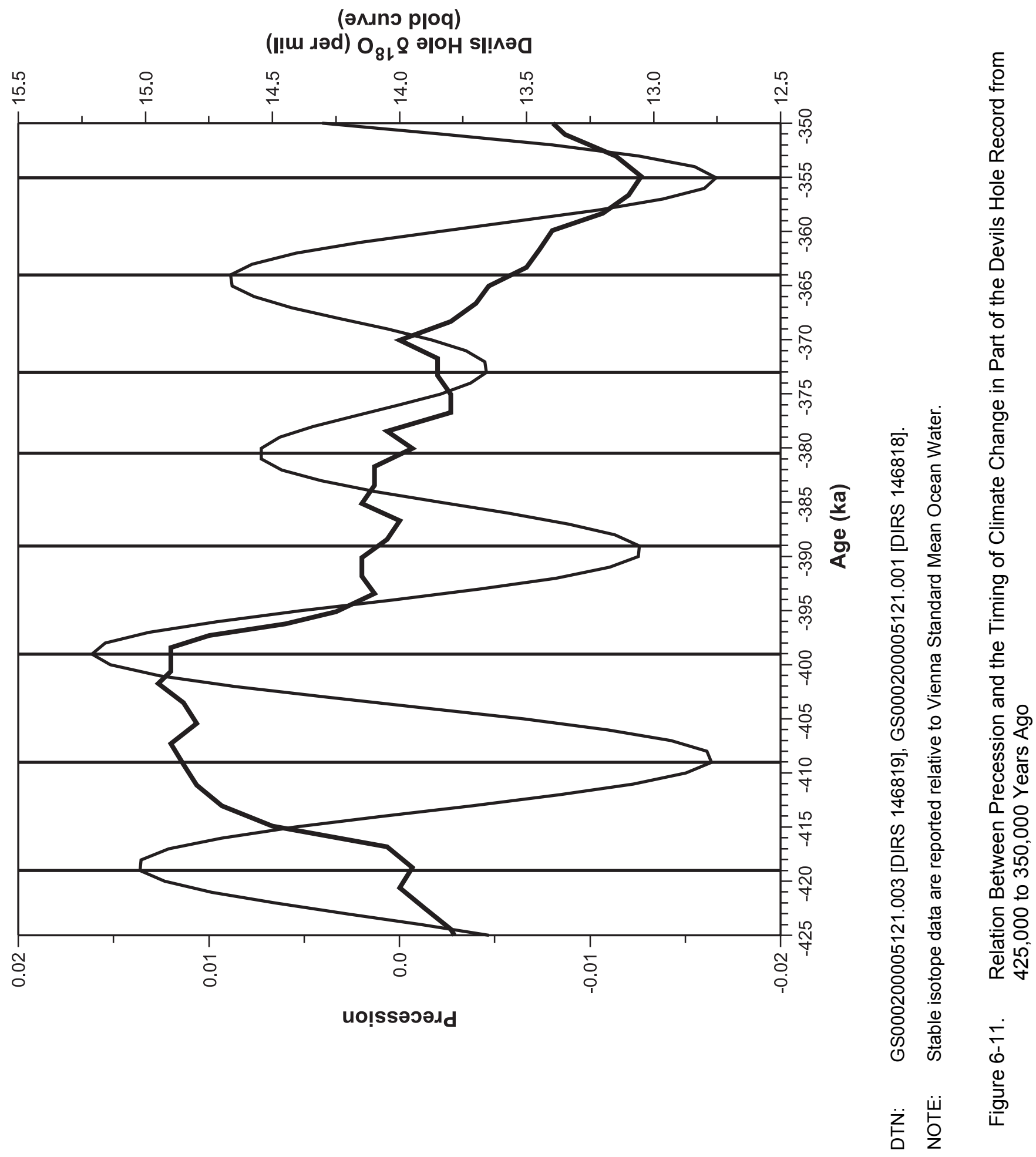


Inspection of the precession curve in Figure 6-10 (DTN: GS000200005121.002 [DIRS 146817]) shows that it is similar to the precession curve in Figure 6-11 (Berger and Loutre 1991 [DIRS 108910], DTN: GS000200005121.001 [DIRS 146818]). Presuming the future precession curve times climate change and marks the multitude of intermediate climates that exist between interglacial and glacial climates, then such intermediate climates will characterize southern Nevada climate for approximately the next 30,000 years. Then around 30,000 years from now climate will move into the full glacial climate and will have moved out of the full glacial by about 50,000 years from now.

\subsection{THE NATURE OF PAST AND FUTURE CLIMATE}

The third assumption in this analysis is that a general relation exists between the nature of climate characteristics of past glacial and interglacial climates and the sequence of those climates in the long 400,000-year earth-orbital cycle. This is the most difficult assumption to deal with, because support for it depends on the interpretation of paleoenvironments from the penultimate 400,000-year cycle and data from that cycle are limited. If the temperature and precipitation characteristics of past glacial and interglacial climate couplets differ from each other in a systematic way through a particular 400,000-year cycle, but the sequence of climate couplets in adjacent 400,000-year cycles are similar, then this relation provides a criterion for the selection of particular past climates as an analog for future climates in the next 10,000 years or perhaps longer at Yucca Mountain. If this assumption is not accepted, then the future climate bounding estimates would depend on a conservative estimate of climate or in other words on the extreme temperature (very cold) and precipitation (very wet) values from the previous 400,000-year cycle instead of values within the extremes.

Using this relation, the glacial and interglacial climates of the last 400,000-year orbital cycle, divided into OISs as shown in Figure 6-3, will serve as sequential analogs for future climates during the next 400,000 years. Although a strict repetition of climate characteristics is not expected or implied from the available data, the general characteristics (the greatest effective moisture within the next 400,000 years) of future precipitation and temperature for a particular interglacial/glacial couplet will be similar to the corresponding OIS couplet in the past 400,000-year sequence. Because of tectonic change and other long-term climate forcing functions, climate change on the million-year time scale should change in a non-cyclic way, and the sequential nature of climate characteristics in non-adjacent 400,000-year orbital cycles may be dissimilar from each other.

\subsubsection{Basis for and General Climate History of the Last 400,000 Years}

Comparison of climate series from different 400,000-year cycles requires that climates from the last 400,000-year cycle be known in enough detail to serve as a basic reference for comparison of climates in older 400,000-year cycles. If the hypothesis of repetition of climates in sequence is accepted, the long Yucca Mountain regional climate sequence also provides the future climate analog for the next 10,000 years. Although the Devils Hole stable isotope record (Figure 6-3) (Landwehr et al. 1997 [DIRS 109124], DTN: GS000200005121.003 [DIRS 146819]) provides the best-dated record for sequence study, it does not provide a means of determining the magnitude, that is the nature, of climate events. Therefore, another record, the microfossil record 
from cores drilled at Owens Lake, California, is used instead to reconstruct a climate history for the last long orbital cycle.

The primary data source for this discussion is the Owens Lake micropaleontological record of diatoms and ostracodes (DTN: GS030908315121.001 [DIRS 171152]; GS031108315121.002 [DIRS 170227]; GS970708315121.002 [DIRS 106508]; GS031108315121.003 [DIRS 168533]), and this discussion will focus on the ostracodes, as their story is similar to the diatoms. Diatom data will be used when necessary to support the ostracode story. A composite stratigraphic distribution of ostracodes from cores taken in the Owens Lake Basin is shown in Figure 6-12. The relationship between the ostracode species assemblages and the Owens Lake hydrology, OIS, and climate, are discussed by Forester et al. (1999 [DIRS 109425]) and CRWMS M\&O (1998 [DIRS 100127], p. 4.2-16 to 4.2-22), among others, and those discussions will only be briefly repeated here. These data are presented in relation to the OIS, which are widely accepted values used as climate benchmarks. OIS, also referred to as oxygen isotope states, ages have been established in Imbrie and Imbrie (1986 [DIRS 109117]), CRWMS M\&O (1998 [DIRS 100127]), and Winograd et al. (1997 [DIRS 100096]). The Owens Lake chronology in relation to OIS is discussed to corroborate the information used in the future climate analysis for Yucca Mountain.

The Owens Lake Basin is located on the eastern side of the Sierra Nevada Mountain Range (Figure 6-1). During the winter season the polar air masses expand (see discussion in Section 6.2), resulting in an alignment of the storm track with the Sierra Nevada Mountains. The persistence and strength of the storm track is a key factor in determining Sierran snowpack and in turn the snowpack determines the amount of runoff available for surface-water flow, that is, flow above base flow in the Owens River.

During an interglacial climate, surface-flow is typically seasonal, but during glacial climates surface-flow probably persisted throughout the year or when it did not, evaporation in the Owens Basin was greatly reduced from present-day, due to colder air temperatures. The present-day high evaporation in the Owens Basin, estimated to be about $1,500 \mathrm{~mm}$ relative to $140 \mathrm{~mm}$ average local precipitation ["Paleoclimatic Record in the Upper Quaternary Sediments of Searles Lake, California, U.S.A" (Smith 1976 [DIRS 109167])], would support a saline Owens Lake, if surface and base flow were not diverted to Los Angeles. Thus, under natural conditions present-day annual flow is not sufficient to fill and spill Owens Lake. When the Owens River flow was greater and or evaporation was lower (low MAT) during glacial and glacial-transition climates, the lake did fill and spill, and was filled with freshwater. Primarily because of its location, the Owens Lake climate signal is dominated by winter precipitation and summer evaporation. Summer precipitation is typically limited, because tropical cyclonic activity does not usually extend into the Owens Basin from the southeast. "Perspective on Great Basin Paleoclimates" (Kay 1982 [DIRS 109121]), among others, documents higher levels of summer precipitation associated with tropical storms. There is some indication from the fossil record, discussed below, that summer precipitation was an important contributor to Owens Lake hydrology in the past. 

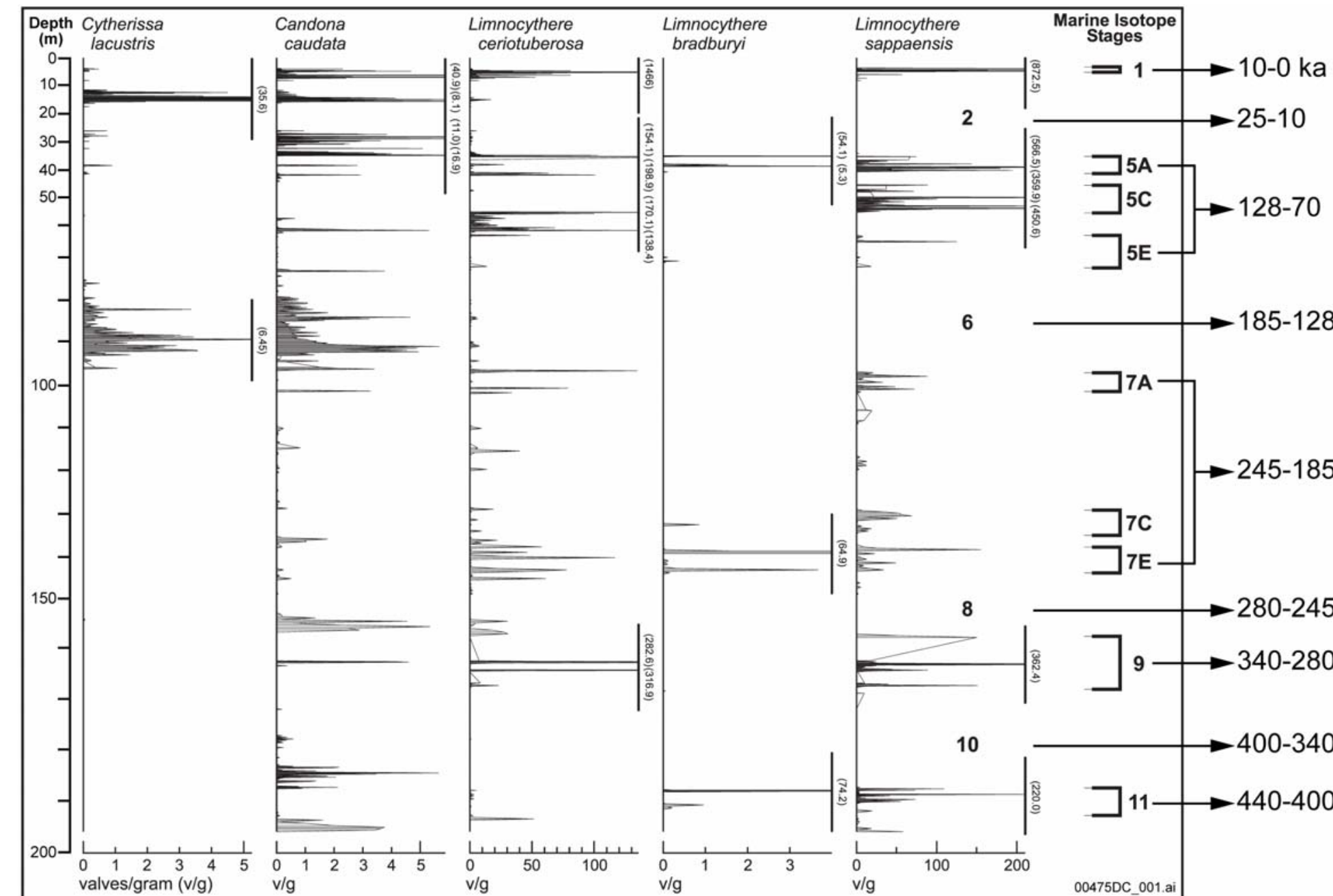

Source: Forester et al. (1999 [DIRS 109425], Figure 7]).

NOTE: Interglacial marine isotope stages (odd numbers) shown in the right column, inferred glacial marine isotope stages (even numbers) shown under

L. sappaensis column are from Forester et al. (1999 [DIRS 109425]), Figures 8 and 9, pp. 19 and 20, and CRWMS M\&O (1998 [DIRS 100127), Table 4.2-1, and Winograd et al. (1997 [DIRS 100096]). Bars centered on data spikes indicate data points beyond the scale of the graph, values to the right of bars are data values at spike apex. This figure is used for corroborating purposes only.

Figure 6-12. Owens Lake Ostracode Species Stratigraphic Distribution 
A relation between total dissolved solids (TDS) in the lake water, flow in the Owens River, and level of evaporation in the Owens Basin exists. Further, flow in the Owens River and level of evaporation in the Owens Basin are directly related to climate. When the Polar Lows were resident in the region, as during some glacial periods, Sierran snowpack and hence surface-water flow was greatly increased, and evaporation in the basin was lower (both actual MAP and effective moisture, which is MAP minus evaporation, were high). If Arctic High air were resident in the region, then evaporation in the Owens Basin must have been much lower than today, due to very cold temperatures, so surface-flow likely was at some intermediate level relative to interglacial and the high-MAP, Polar-Low-dominated climates, so effective moisture also would have been high and the lake would spill.

Ostracode and diatom species environmental tolerances provide a way to interpret the relative TDS of the Owens paleolake, and the relative temperature of its water. The TDS and water-temperature information is then interpreted in climate terms. Thus, the stratigraphic profiles of microfossil species provide a way to interpret regional climate history from their implied paleoenvironments, and hence insight into glacial and interglacial climate change, and a means to compare past climates with each other. Further, North American lacustrine ostracode species biogeography is known well enough to use it to understand the general nature of climate change in Owens Lake rather than just paleoenvironmental change. Unlike common plant species [Atlas of Relations Between Climatic Parameters and Distributions of Important Trees and Shrubs in North America - Introduction and Conifers (Thompson et al. 1999 [DIRS 109462]); 1999 [DIRS 109470])] however, the biogeographic distributions of lacustrine ostracodes are not mapped, so can not be quantified in climate terms. Thus, particular climate parameters are not as readily derived from ostracode assemblage biogeographic data as from plant biogeographic data. Nonetheless, the occurrence of various ostracode species does provide a paleogeographic sense (polar, tropical, or temperate) of the nature of past climates.

Actual climate parameters, however, do not have to be generated from the microfossil species profiles to reconstruct long-term climate, as long as the characteristics of, for example, a given glacial or interglacial climate can be properly evaluated relative to others. The relative climate reconstruction is then compared, that is calibrated, with two absolute climate control points: 1) present-day meteorological data and 2) the reconstruction of the last glacial climate based on plant macrofossils recovered from packrat middens throughout the region (Thompson et al. 1999 [DIRS 109470]). Thus the knowledge of ostracode and diatom TDS tolerances, ostracode relative water-temperature preferences, and ostracode species biogeography provide a means of directly comparing general or relative nature of the past glacial and interglacial climates during the last 400,000 years.

A composite stratigraphic distribution of common lacustrine ostracode species from the Owens Lake record for about the last 425,000 years is shown in Figure 6-12 (DTN: GS970708315121.002 [DIRS 106508], GS031108315121.003 [DIRS 168533]). The sediment depths on the y-axis have been correlated to marine oxygen isotope stages given on the right side of the figure (Forester et al. 1999 [DIRS 109425], CRWMS M\&O 1998 [DIRS 100127], pp. 4.2-19 to 4.2-20, Table 4.2-1). As sediment accumulation rates are not expected to be constant over long periods of time, the chronology related to the OIS should be viewed as an approximation. Thus in the absence of direct dating, other means must be used to date the sediments from the cores. One such means is to identify the interglacial and glacial 
stratigraphic environmental signature from the Owens Lake record and then correlate that signature with the Devils Hole record. Because of this approximation, the Owens Lake chronology shown in Figure 6-12 is provided here as a corroborating reference only and is not used in the analysis documented in this report.

Forester et al. (1999 [DIRS 109425]) and CRWMS M\&O (1998 [DIRS 100127], p. 4.2-18 to 4.2-22) discuss the relation between diatom and ostracode species, Owens paleolake chemistry, and climate. Briefly, during interglacial climates, when, at least on a seasonal basis, Owens River base flow is common, the lake becomes both saline and alkaline, that is, its solute chemistry is characterized by a high alk/calcium ratio. Alk is total alkalinity expressed as an equivalent amount of calcium carbonate $\left(\mathrm{CaCO}_{3}\right)$.

Limnocythere sappaensis requires the high alk/Ca water associated with base flow in the Owens River to survive ["Relationship of Two Lacustrine Ostracode Species to Solute Composition and Salinity: Implications for Paleohydrochemistry" (Forester 1983 [DIRS 109023])] and such waters characterize the warm climate episodes at Owens Lake ["Climatic/Hydrologic Oscillations Since 155,000 Yr B.P. at Owens Lake, California, Reflected in Abundance and Stable Isotope Composition of Sediment Carbonate" (Menking et al. 1997 [DIRS 109444])]. Each abundant $L$. sappaensis zone is identified with an interglacial (warm climate) OIS number starting with 1 and counting backwards in time (Figure 6-12) (DTN: GS970708315121.002 [DIRS 106508], GS031108315121.003 [DIRS 168533]) (CRWMS 1998 [DIRS 100127], Table 4.2-1; see Winograd et al. 1997 [DIRS 100096], for further explanation of OISs). Warm climate episodes also include the warm periods within glacials such as OIS substages 5C and 5A. Further, OIS 9, like 7 and 5, has warm and cool substages, but the substages are not differentiated here due to loss of core. The L. sappaensis OIS 1 interval (Figure 6-12) is only a subset of the true OIS 1, which extends from present-day to about 10,000 years ago, so the other L. sappaensis intervals also may be subsets of the respective OIS stages they are thought to identify. Assuming the Owens Lake sedimentary record [An 800,000-Year Paleoclimatic Record from Core OL-92, Owens Lake, Southeast California (Smith and Bischoff 1997 [DIRS 109480])] is reasonably complete, then the L. sappaensis stratigraphic profile identifies all sustained warm climates, in other words, those with low effective moisture.

Comparing the same OIS intervals in the Devils Hole $\delta^{18} \mathrm{O}$ record (Figure 6-3) (Landwehr et al. 1997 [DIRS 109124], DTN: GS000200005121.003 [DIRS 146819]) and the Owens Lake ostracode record (Figure 6-12) (DTN: GS970708315121.002 [DIRS 106508], GS031108315121.003 [DIRS 168533]) indicates a relationship although not a perfect correlation. If abundant L. sappaensis intervals represent saline lakes when the Owens River is at base flow and hence warm, dry climates, then the times between such intervals should contain evidence of surface flow, both freshwater and cold conditions; with Owens Lake filling and spilling under a polar, cold air mass. That is, if the ostracode profiles shown in Figure 6-12 represent the glacial and interglacial climates for the past approximately 400,000 years, then there should be an alternating ostracode assemblage reflecting fill and spill cold lakes followed by another assemblage reflecting closed saline lakes and so on.

Cytherissa lacustris and Candona caudata are ostracodes that require low salinity water in order to grow and reproduce (CRWMS M\&O 1998 [DIRS 100127], p. 4.2-20 to 4.2-21), so their presence in this record (DTN: GS970708315121.002 [DIRS 106508], GS031108315121.003 
[DIRS 168533]) implies a fill and spill lake (Figure 6-12). Limnocythere ceriotuberosa is common in lakes receiving seasonal surface flow followed by a base-flow phase, so its presence implies greater surface flow than is typical today, but less than that during the periods when $C$ lacustris and C. caudata are common. The stratigraphic record in Figure 6-12 shows that all of the intervals between those identified by L. sappaensis variously contain C. lacustris and $C$. caudata with common occurrences of $L$. ceriotuberosa. Thus the expected sequence of taxa representing fill and spill, freshwater, cold lakes through closed, saline lakes is present in the record. This implies the record is complete, and moreover, is comparable with the sequence of glacial and interglacial cycles recorded by other records reflecting global climate change such as the Devils Hole $\delta^{18} \mathrm{O}$ record.

The inferences about timing and stratigraphy from the distribution of Limnocythere sappaensis and other ostracodes (DTN: GS970708315121.002 [DIRS 106508]) are in part supported by a recent revision of the Owens Lake chronology ["Calibrating Late Quaternary Terrestrial Climate Signals: Radiometrically Dated Pollen Evidence from the Southern Sierra Nevada, USA” (Litwin et al. 1999 [DIRS 109440])]. Using a high-resolution pollen stratigraphy generated in both Searles Lake, California and in Owens Lake, Litwin et al. (1999 [DIRS 109440]) correlate an alpha spectrometric uranium series chronology from Searles Lake to Owens Lake. They did not date the Holocene in Searles Lake, but their pollen stratigraphy for OIS 5A, 5C, and 5E agrees with the L. sappaensis chronology proposed here. The ostracodes and pollen data do not correlate as well in the older part of the core where the pollen analyses were based on lower resolution pollen analysis [E-mail Correspondence Between D.R. Muhs (U.S. Geological Survey) and R.M. Forester (U.S. Geological Survey) (Litwin 1999 [DIRS 138436])]. More recent, but unpublished higher resolution analyses have changed the pollen correlation chronology (Litwin 1999 [DIRS 138436]), but its effect on the ostracode chronology has not been analyzed.

Assuming the Owens Lake sedimentary record (Smith and Bischoff 1997 [DIRS 109480]) is reasonably complete from the discussion above, the ostracode record provides the following insights into the regional climate history. The ostracode species stratigraphic profile shown in Figure 6-12 (DTN: GS970708315121.002 [DIRS 106508], GS031108315121.003 [DIRS 168533]) shows that Cytherissa lacustris is common in the early OIS 2 period about 10,000 to 24,000 years ago (CRWMS M\&O 1998 [DIRS 100127], Table 4.2-1) which is the last full-glacial period, and then again between about 120,000 to 170,000 years ago (CRWMS 1998 [DIRS 100127], Table 4.2-1), which is within OIS 6 (the penultimate glacial period). C. lacustris also occurs at a single horizon within the OIS 8 period (Figure 6-12). C. lacustris was not found in sediments attributed to OIS 10, even though a large number of samples were examined from this interval. Candona caudata is also common through the same horizons as C. lacustris and at many horizons within glacial intervals where C. lacustris does not occur.

Cytherissa lacustris is a taxon that lives in small to large lakes in the Boreal Forest and Arctic Circle ["Freshwater Ostracodes of Canada. Part IV. Families Ilyocyprididae, Notodromadidae, Darwinulidae, Cytherideidae, and Entocytheridae" (Delorme 1970 [DIRS 108953])], where the climate is dominated by polar air masses. C. lacustris is known only from a few large lakes south of Canada and Alaska, such as the Great Lakes. It is absent from deep, high mountain lakes in the Sierra Nevada Mountains. The distribution of present-day C. lacustris supports the interpretation that it requires cold and fresh [highest TDS occurrence about 300 milligrams per 
liter, mg/L, "Methods in Quaternary Ecology \#7. Freshwater Ostracodes" (Delorme 1989 [DIRS 109421])] water to survive. Candona caudata lives in Canada and Alaska, but also is common in many locations in the continental 48 states. The southernmost known distribution for C. caudata is in the Pahranagat Lakes, Nevada, and the known upper TDS limit is about 3,000 mg/L ["Late Quaternary Paleolimnology of Walker Lake, Nevada" (Bradbury et al. 1989 [DIRS 109413])]. Thus both C. lacustris and C. caudata imply fresh fill and spill lakes, and hence wetter than present-day climates, but the $C$. lacustris intervals also imply a colder and perhaps fresher lake than the C. caudata intervals without C. lacustris.

The stratigraphic profiles of Cytherissa lacustris and Candona caudata (Figure 6-12) (DTN: GS970708315121.002 [DIRS 106508], GS031108315121.003 [DIRS 168533]) indicate that glacial period OIS 10 was the warmest glacial period, followed by OIS 8, and OIS 6 was the coldest glacial period. The abundance of $C$. caudata during the warm glacial periods implies MAP was high in order to maintain a fresh and spilling lake, although the lake need not be as fresh as it was during the C. lacustris intervals, so the C. caudata lakes may imply lower effective moisture levels. Significantly, during the coldest glacial, a fresh and spilling lake could be maintained largely by low evaporation with only modest gains in MAP above present-day levels, so a relatively low MAP, but a high effective moisture level. Thus the cold glacials do not require, but do not preclude, large increases in MAP to create and sustain a freshwater lake.

The ostracode Limnocythere ceriotuberosa commonly lives in saline to freshwater lakes in the United States and on the central Canadian prairies where its habitat is influenced seasonally by polar and westerly air masses (Figure 6-13). It is often found in lakes with seasonal changes in TDS, resulting from a seasonal shift from excess surface flow to base flow. In Owens Lake, L. ceriotuberosa likely reflects a lake that fills and spills in some years, but is typically at some intermediate depth between the C. lacustris and C. caudata continuously spilling lakes, and the low-level base-flow-supported saline lakes of Limnocythere sappaensis (DTN: GS970708315121.002 [DIRS 106508], GS031108315121.003 [DIRS 168533]). Periods when $L$. ceriotuberosa was common in the Owens Lake stratigraphic profile imply intermediate lakes between those produced by full-glacial climates and those supported by interglacial climates, and thus indicate intermediate climates. Intermediate climates might be somewhat wetter or cooler than present day or a combination of both, but not as wet or cold as the full-glacial climates.

The past warm, evaporative, low-MAP climates are represented by Limnocythere sappaensis as discussed above. The occurrence of this taxon in the Owens Lake record (DTN: GS970708315121.002 [DIRS 106508], GS031108315121.003 [DIRS 168533]) indicates a saline lake supported largely by base flow, and hence a present-day-like climate or a drier/warmer climate than present-day. It does not, however, allow for a climate that is much wetter/cooler than today, because a wetter/cooler climate would result in an influx of dilute high-elevation water that is lethal to L. sappaensis. As shown in Figure 6-12, numerous $L$. sappaensis climates existed in the region during this period corresponding to OIS 11.

An interesting subclimate associated with the L. sappaensis climates is indicated by the presence of Limnocythere bradburyi. Today, the biogeographic distribution of L. bradburyi is centered in central Mexico ["Limnocythere bradburyi N. SP.: A Modern Ostracode from Central Mexico and a Possible Quaternary Paleoclimatic Indicator" (Forester 1985 [DIRS 109423])] where its habitat 
is influenced seasonally by the subtropical easterlies or the subtropical highs (Figure 6-13). The northern biogeographic limit, in shallow-water environments, is the January frost line in the southwestern U.S., indicating it is cold-water sensitive (Smith and Forester 1994 [DIRS 109456]). Other areas in the southwest that are warm enough are too dry to sustain shallow lakes long enough for L. bradburyi to complete its life cycle. However, past climates that were warmer and wetter than today, including those where monsoon flow through the southwest was enhanced, would sustain shallow, warm lakes promoting a northward range expansion of this species. The fossil distribution of this taxon extends into northern Nevada (Forester 1985 [DIRS 109423]; "Late Quaternary Paleoclimate Records from Lacustrine Ostracodes" (Forester 1987 [DIRS 109033]); Bradbury et al. 1989 [DIRS 109413]) and elsewhere and appears to have done so during many past warmer and wetter climate episodes.

Limnocythere bradburyi would not live in Owens Lake during times of higher surface flow, when such conditions resulted from resident polar air masses, which would result in a cold lake. If $L$. bradburyi could live in cold water, then its present distribution would be more northerly, as it was in the past. The sporadic occurrences of L. bradburyi in the Owens Lake record (Figure 6-12) (DTN: GS970708315121.002 [DIRS 106508], GS031108315121.003 [DIRS 168533]) are always associated with Limnocythere sappaensis lakes, which reflect warmer climates. It does not occur throughout the L. sappaensis intervals, because the salinity tolerance of $L$. sappaensis is higher and its temperature tolerance lower than that of $L$. bradburyi.

The present-day northern extent of the southwestern monsoon, showing the area dominated by summer precipitation (Muhs 1999 [DIRS 128077]), is south of the Owens Basin and Yucca Mountain (Figure 6-14). However, given a modest and uniform expansion of the present-day summer rain regime, both Yucca Mountain and the Owens Basin would be included. The inclusion of the Owens Basin should change the basin's hydrology to reflect a summer, rather than winter precipitation regime, which would be atypical for the basin. A dilution of a warm climate saline lake and/or a shift to year round warm waters due to an overall expansion of the tropical system and contraction of the polar system, would provide an environment like those where Limnocythere bradburyi lives today (Forester 1985 [DIRS 109423]; Smith and Forester, 1994 [DIRS 109456]). The rarity of $L$. bradburyi in the fossil record (DTN: GS970708315121.002 [DIRS 106508], GS031108315121.003 [DIRS 168533]) at Owens Lake during the last 425,000 years reflects the rarity of tropical regime dominance over winter regimes in the region.

The ostracode species stratigraphic profiles (Figure 6-12) (DTN: GS970708315121.002 [DIRS 106508], GS031108315121.003 [DIRS 168533]) provide relative climate scenarios based on inferences about the linkage between climate and paleolimnology in the Owens Lake Basin for the past 400,000 years. In order to assign approximate values of MAT and MAP to the relative climate scenario, the relative scheme must be "quantified" by comparing it to quantified climate estimates. Two climates were selected to calibrate the nature of all of the climates recorded in the Owens Lake record from the relative climate scenario: the present-day climate and the reconstructed climate for OIS 2 (Thompson et al. 1999 [DIRS 109470]). Climate parameters for both are estimated for an elevation equivalent to the top of Yucca Mountain. 


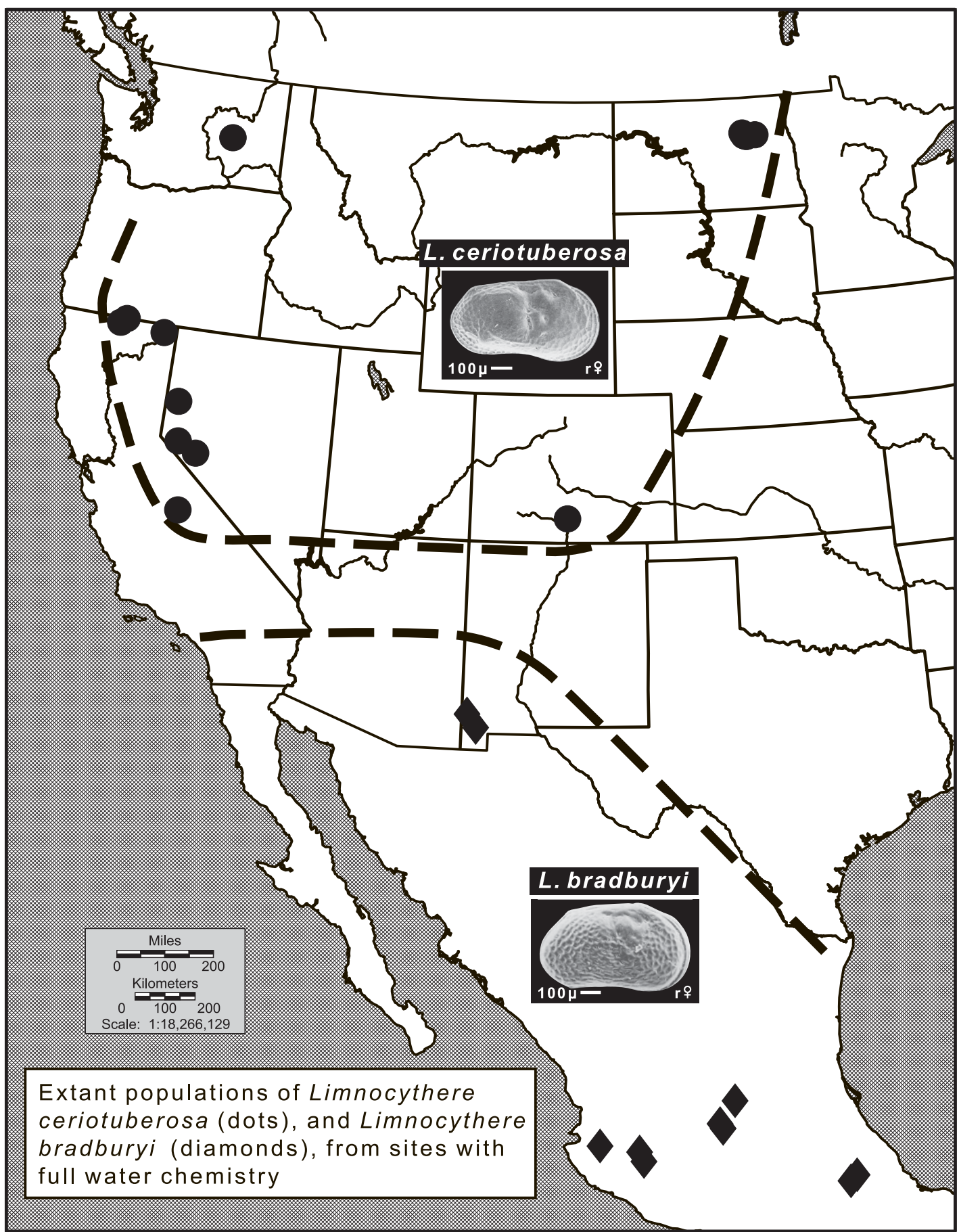

Source: Modified from "Estimating Past Precipitation and Temperature from Fossil Ostracodes" (Smith and Forester 1994 [DIRS 109456], Figure 1).

NOTE: One $\mu$ equals $10^{-6}$ meter, " $r$ " indicates right-hand valve, " 우 " indicates female.

Figure 6-13. Present-day Biogeographic Distribution of Two Ostracode Species Found in the Owens Lake Fossil Record Illustrating a Relation Between Biogeography and General Features of Climate (Figure 6-2) 
The present-day climate is characterized by: 1) Hot, dry, very evaporative summers due to the residence of the Subtropical Highs, 2) low levels of MAP due to both the summer air masses and to a location east of the Sierra Nevada Mountains, and 3) occasionally wet but typically dry and relatively warm winters. Present-day MAP and MAT as estimated by Thompson et al. (1999 [DIRS 109470]) for Yucca Mountain are about $125 \mathrm{~mm}$ and $13.5^{\circ} \mathrm{C}$ respectively. These values are lower than those commonly used by the Yucca Mountain Project, but are derived from a longer set of historical meteorological data and are interpolated to Yucca Mountain from area rather than project stations. The Thompson et al. (1999 [DIRS 109470]) numbers are closer to the Nevada region 3 and 4 averages, which represent the last 100 years, rather than just the last two decades. The present-day warm interglacial climate at Yucca Mountain is assumed to be typical of all of the Limnocythere sappaensis records found in the Owens Lake climate record (DTN: GS970708315121.002 [DIRS 106508], GS031108315121.003 [DIRS 168533]). By proximity, as climate is a regional and not a local phenomenon, the existence of warm evaporative climates at Owens Lake implies that such climates also exist at Yucca Mountain.

The last full-glacial climate (OIS 2) at Yucca Mountain was characterized by: 1) Cold, wet (snowy) winters due to the residence of either Polar Lows or Arctic Highs, creating high effective moisture, and 2) cool, dry summers resulting from both the presence of cool, westerly flows and the absence of Subtropical Highs in the region. The OIS 2 full-glacial climate estimates at Yucca Mountain for MAP is about 266 to $321 \mathrm{~mm}$ and for MAT is about $7.9^{\circ} \mathrm{C}$ to $8.5^{\circ} \mathrm{C}$ (Thompson et al. 1999 [DIRS 109470]). These estimates are derived from a study of the plant macrofossils found in packrat middens in the Yucca Mountain region.

The values given above provide climate numbers that can be applied to the relative climate scheme developed from the microfossil record in the Owens Lake sediments. Therefore, for example, OIS 10 was wetter and warmer than OIS 2 and OIS 6 . OIS 6 was colder than OIS 2 , but probably had an MAP similar to OIS 2, to possibly higher than OIS 2. Therefore, OIS 10 may have had an MAP that was much greater than about $300 \mathrm{~mm}$ and an MAT that was higher than $8^{\circ} \mathrm{C}$. OIS 6 by comparison was colder than $8^{\circ} \mathrm{C}$ and had an MAP of about $300 \mathrm{~mm}$ or higher. The Limnocythere ceriotuberosa intermediate climates were typically drier and warmer than OIS 2, but wetter and cooler than the present-day values. Therefore, the L. ceriotuberosa intervals had an MAP that was greater than $125 \mathrm{~mm}$, but less than about $275 \mathrm{~mm}$ and an MAT above $8^{\circ} \mathrm{C}$ but below about $13^{\circ} \mathrm{C}$. The Limnocythere bradburyi climates were wetter and slightly warmer than the present-day climates.

Lastly, the stratigraphic distance between the various ostracode species assemblages in the Owens Lake core are small, implying the interpreted climate changes occurred rapidly. Using the Owens Lake chronology, the timing of climate change is often occurring in decades to centuries and rarely in millennia. Such rapid changes in climate, however, are not generally from the driest and warmest to the wettest and coldest climates, but rather are transitioning through many intermediate climate states. 


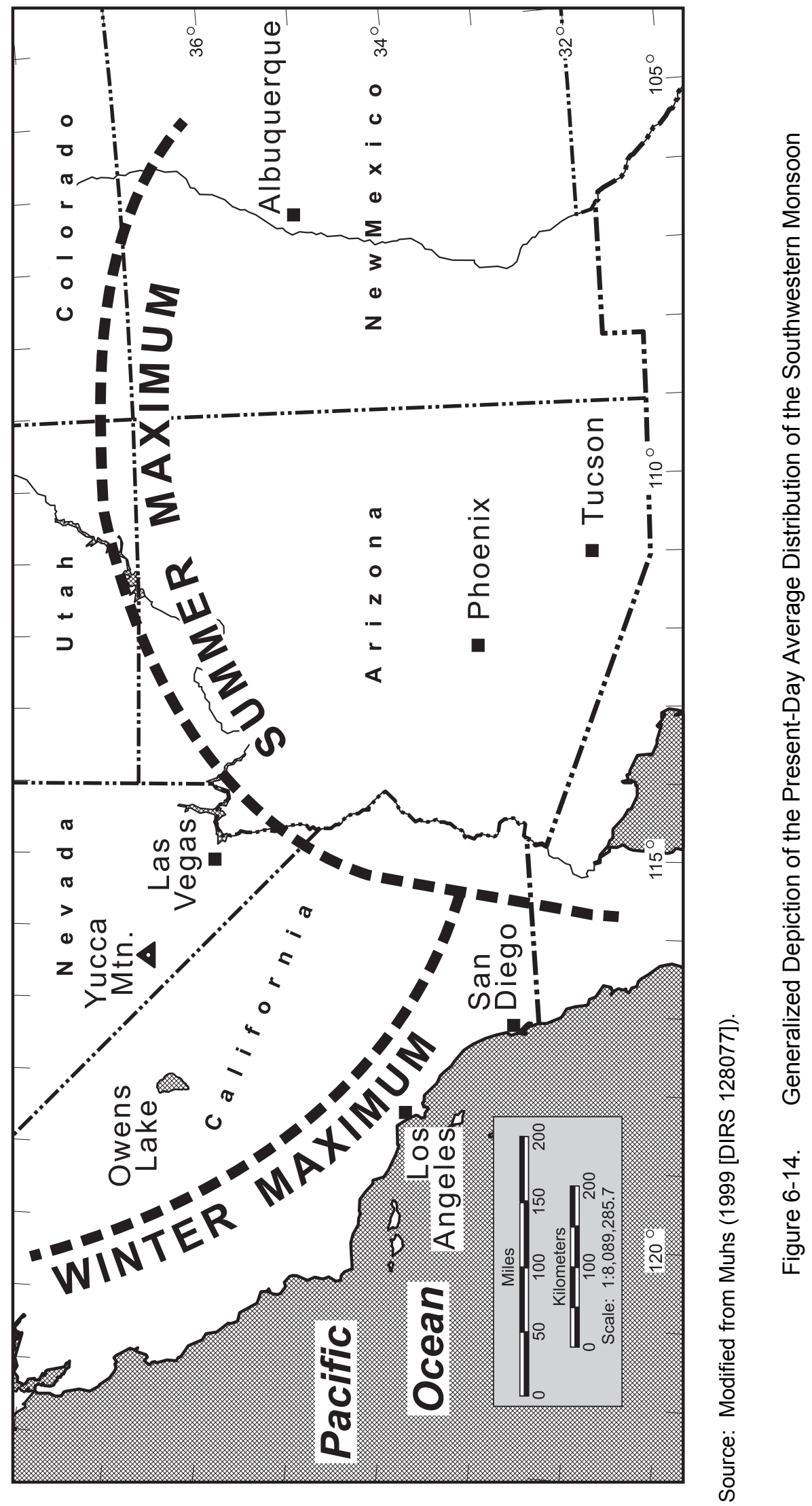




\subsubsection{Repetition of Past Climates}

The assumption discussed in this section is that a general relation exists between the characteristics of past glacial and interglacial climates and the sequence of those climates in the long 400,000-year orbital cycle. Because the characteristics of past glacial and interglacial climates differ from each other and appear to do so in a systematic way, this relation provides a criterion for selection of a particular past climate as an analog for future climate.

The ostracode fossil record from Owens Lake cores (DTN: GS970708315121.002 [DIRS 106508], GS031108315121.003 [DIRS 168533]) provides the basis to make a number of general observations about paleoclimate. Some of these observations for the past 400,000 years include:

1. The third glacial period in the sequence (OIS 6) was the coldest of the glacial climates and had the highest level of effective moisture, but not necessarily the highest MAP,

2. The first glacial period in the sequence (OIS 10) was the warmest, and perhaps the wettest of the glacial climates, but probably had a moderate level of effective moisture relative to higher effective moisture in the colder glacial periods in the sequence,

3. There were numerous interglacial and related warm climate periods such as OIS stages $5 \mathrm{~A}$ and $5 \mathrm{C}$, when the climate was warm and dry with low effective moisture,

4. The warm, dry climate periods were occasionally punctuated by warm and wet, but low effective moisture, tropical-dominated climates,

5. There were extensive periods when climate characteristics were intermediate in nature between full-glacial high effective moisture and interglacial warm-climate low effective moisture periods, and

6. The rate of change between the various climates was rapid, apparently occurring on a decade to century time scale.

The Owens Lake ostracode hydrologic/climatic record (DTN: GS970708315121.002 [DIRS 106508], GS031108315121.003 [DIRS 168533]), as partially summarized in 1 through 6 above, indicates that the regional climate history for the past 400,000 years was a complex array of climates. Each of the glacial climates OIS 10, 8, 6, 4/2 was different from the others and became colder as the sequence progressed reaching the coldest and most persistent glacial climate with OIS 6 . OIS 6 was followed by a complex set of climates ranging from the wet and warm interglacial OIS 5E to the cold and relatively short-lived glacial climates, OIS 4 and 2.

In terms of an orbital clock, today the climate system resides at the beginning of a new 400,000-year cycle. If the cycle repeats, then the transition climate at the beginning of the last 400,000-year cycle (OIS 11 to OIS 10) may be a more probable analog for future climate than some other interglacial to glacial transition. Evidence in support of this idea comes from comparing the last cycle (400,000 years ago to present), hereafter referred to as the younger long climate cycle (YLCC), to the 400,000-year cycle before the last one, so 800,000 to 400,000 years ago, hereafter referred to as the older long climate cycle (OLCC). 
In comparing the relation between the OLCC and the YLCC, the southwestern regional climate records from the OLCC are limited, and existing records are often poorly dated or not interpreted in the detail that would be preferable for this study. Further, long-term climate forcing functions, primarily tectonic, are probably not "constant" in this time frame and hence may contribute to climates in the OLCC time frame in a different way or with different magnitude than those from the YLCC or those in the future. Nonetheless, some information is available from the region, including Death Valley, and, more generally from the global marine records. A number of studies interpret climate from regional records that are dated or believed to be dated between 800,000 and 400,000 years ago, for example, see "Paleohydrologic Regimes in the Southwestern Great Basin, 0-3.2 my Ago, Compared with Other Long Records of 'Global' Climate" (Smith 1984 [DIRS 109168]); "A 36Cl Chronology of Lacustrine Sedimentation in the Pleistocene Owens River System" (Jannik et al. 1991 [DIRS 109434]); Whitney and Harrington (1993 [DIRS 107303]); "A Late Pliocene to Middle Pleistocene Pluvial Lake in Fish Lake Valley, Nevada and California" (Reheis et al. 1993 [DIRS 109452]); "Highest Pluvial-Lake Shorelines and Pleistocene Climate of the Western Great Basin" (Reheis 1999 [DIRS 109454]); "Quaternary Stratigraphy and Geomorphology of Death Valley" (Knott 1999 [DIRS 109436]); and "Reinterpretation of the Burmester Core, Bonneville Basin, Utah" (Oviatt et al. 1999 [DIRS 109448]). A general discussion is given in "Continental Paleoclimatic Records and Their Significance" (Smith 1991 [DIRS 109476]; "Stratigraphy and Chronology of Quaternary-Age Lacustrine Deposits" (Smith 1991 [DIRS 109478]).

Because the older climate records, those from the OLCC or even older, are poorly dated, comparison of paleoenvironmental events from a record at one site to events at another site is difficult if not speculative. Thus the level of past climate detail, such as the six observations given above about the YLCC in the Owens Lake Basin, is not available from the older records. However, aspects of the events seen in the younger part of the Owens Lake record can be identified in the older records. During the YLCC the coldest and highest effective moisture climate was interpreted, based on the ostracode and other records, as the third glacial (OIS 6) in the YLCC. Support for the interpretation, for example, comes from the OIS 6 lake in Death Valley that was at least 175 meters deep, but only about 70 meters deep during OIS 2 (Ku et al. 1998 [DIRS 109438]).

If the OLCC and YLCC are similar, the third glacial period in the OLCC (OIS 16, from about 680,000 to 630,000 years ago) is expected to have had the coldest and highest level of effective moisture in that cycle. Deciphering MAT or other climate characteristics from the OLCC is not straightforward from the available data, which mostly are lake levels. Lake level, as discussed above and by Smith (1991 [DIRS 109476]), may be a product of higher MAP or colder temperature or some combination of both. Estimation of the general order of climate change magnitude from the size of old lakes does, however, provide insights to compare the climate characteristics of glacial periods within and between 400,000-year cycles.

Reheis (1999 [DIRS 109454], Figs. 2 and 3) presents evidence for OIS 16, the third glacial in the OLCC, being the biggest and deepest lake in several basins throughout the Great Basin. Knott (1999 [DIRS 109436]) identifies lake sediments deposited during OIS 16 (and perhaps a somewhat older lake) in Death Valley, but does not distinguish the possible size of the OIS 16 lake from others in the OLCC. Jannik et al. (1991 [DIRS 109434]) suggest a large lake existed in the Searles Basin during OIS 16 that was large enough toward the end of OIS 16 to overflow 
to the Panamint Basin. They also suggest an OIS 18 (about 725,000 to 705,000 years ago) lake may have overflowed to the Panamint Basin and that both of the latter lakes may have overflowed from the Panamint Basin to Death Valley. Similarly, Reheis (1999 [DIRS 109454], Fig. 3) presents some evidence for a large lake during OIS 18. Oviatt et al. (1999 [DIRS 109448]) reinterpret the timing and occurrence of lakes in the Great Salt Lake Basin. They present chronological and environmental evidence from a core for a lake in that basin during OIS 16 and OIS 12 (about 490,000 to 415,000 years ago), but no others during the OLCC. Reheis (1999 [DIRS 109454], Fig. 3) also presents evidence for a large lake during OIS 12, but not as large as the one during OIS 16.

The OIS 16 lakes identified by Reheis (1999 [DIRS 109454]) are much larger and deeper than those from the same basins during OIS 6. Although shoreline elevations are not available, the opposite appears to be true for the lakes in the Great Salt Lake Basin (Oviatt et al. 1999 [DIRS 109448]). The differences in size between the OIS 16 and 6 lakes could be a result of various combinations of temperature and precipitation or simply a different average position of the polar jet stream due to spatial and height differences in the two continental ice sheets. The important aspect of this information for this discussion is that the apparent biggest lakes in the OLCC and YLCC occur during the third glacial in each cycle. The third glacial in each cycle would then seem to have had the highest effective moisture; whether that was generated largely due to cold temperatures, high precipitation, or both, is not known. This type of correspondence again adds support to the application of a 400,000-year climate cycle.

Similarly, Reheis (1999 [DIRS 109454], Fig. 3) suggests OIS 12 lakes also were large, but not as large as those during OIS 16. OIS 12 is in the same position in the OLCC as is OIS 2 in the YLCC, the last (4th) glacial cycle. Ku et al. (1998 [DIRS 109438]) show that the OIS 2 lake in Death Valley was large, but smaller than the OIS 6 lakes. Jannik et al. (1991 [DIRS 109434]) suggest that the Owens drainage lakes filled and flowed into Death Valley during parts of OIS 16,12 , and 6 , among others, but not during OIS 2. The absolute size of a lake in a particular basin is a function of many climate and non-climate factors, but what is important here is that in a given basin, the behavior of a sequence of lakes during the OLCC, that is, the lakes characterizing OIS 20,18,16, and 14/12, appears to be similar to the behavior of a sequence of lakes during the YLCC, that is OIS 10, 8, 6, and 4/2.

Finally, the marine isotope record (Reheis 1999 [DIRS 109454], Fig. 3) provides a general proxy for ice volume, although ocean temperature may also play an important and perhaps unknown role in this record. Marine isotopic profiles during the OLCC generally are similar to those during the YLCC. The largest ice sheets are those from OIS 16, 12, 6, and 2. As continental ice sheets expand in area and become higher in elevation they force the polar air masses to the south. Therefore, large ice sheets should result in cold and or wet climates in the vicinity of Yucca Mountain. Large ice sheets also result in climates in the Yucca Mountain area with cooler summers than today, thus enhancing effective moisture. Conversely, OISs 20, 18, 14, 10, 8, and 4 apparently had smaller or lower ice sheets, potentially allowing for warmer, and thus lower effective moisture climates in the Yucca Mountain region, as perhaps the smaller lakes associated with those periods imply.

The records of paleoclimate are often incomplete, poorly dated, and are interpreted differently by different workers. The information above, however, implies that there is some repetition 
between the types of climate in the OLCC and the YLCC. This provides the basis to suggest that the nature of the next glacial cycle at the beginning of the next 400,000-year cycle may be more like the glacials at the beginnings of the long climate cycles than other glacials within the long climate cycles. Therefore, then the transition from OIS 11 to OIS 10 provides a past analog for forecasting future climate change, and hence the basis used here to establish a potential climate scenario for the next 10,000 years.

Although not based on paleoclimate data, the orbital parameters, especially precession and eccentricity, show strong similarity at the beginning of the YLCC and from now forward in time for the next 100,000 years, which is the beginning of a new 400,000-year cycle (Berger and Loutre 1991 [DIRS 108910], DTN: GS000200005121.001 [DIRS 146818]; and GS000200005121.002 [DIRS 146817]) (compare Figures 7 and 9). As has been discussed above, there is no certainty in whether or not orbital parameters that time climate change also drive climate change. It is possible that orbital parameters drive climate change and may also determine the nature or magnitude of climate change. If this is the case, then position within the long orbital cycles also determines the nature of climate and thus the beginning of the YLCC is the analog for future climate during the next 10,000 years.

\subsection{A FUTURE CLIMATE ANALOG FOR THE NEXT 10,000 YEARS}

On the basis of the assumptions discussed above that 1) climate is cyclic, 2) climate can be timed with an orbital clock, 3) climate sequences repeat themselves in a predictable way, and 4) tectonics or other long-term climate-forcing functions that could result in non-cyclic future climate behavior are constant on the time scales of interest here; the OIS 11/10 transition was selected as the analog for future climate for the next 10,000 years. The timing of and nature of climate change for the next 10,000 years are discussed below.

\subsubsection{Timing of Climate Change for the Next 10,000 Years}

Forecasting the timing of future climate change requires the identification of a past climate sequence that is believed to be part of a cycle that will repeat itself in the future. Forecasting climate by projecting a past climate analogue into the future is very different from model-based prediction. Climate prediction integrates all factors affecting earth's climate into a time-series numerical model that is then run for the particular future times under predetermined boundary conditions. Climate models require particular boundary conditions including ocean surface temperatures at some future point in time that are not available. In general, climate models and the computers they run on can not produce output for long periods of time, such as 10,000 years. Typical output might be five years of data following long computer run times. Present-day science does not know with certainty why climate changes, or know how to numerically describe the change in climate system in a time series, nor is there any agreement about future boundary conditions. Consequently, the discussion below will focus on forecasting future climate.

First a point representing the equivalent to the present day is identified in the YLCC series (a past/present point). Then the next 10,000 years of paleoclimate reconstruction from the past/present point becomes the future climate forecast. The orbital clock that was derived from the Devils Hole chronology (Section 6.4 above) provides the means to approximately identify the past/present point in the Owens Lake record. The graph (Figures 6-7 and 6-8) shows the linkage 
of the present-day position in the orbital clock ( $\mathrm{I}=1,000$ years ago) and the equivalent point

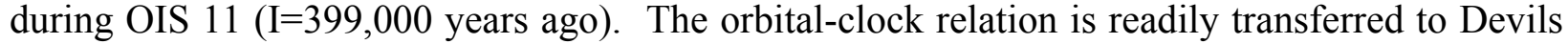
Hole through their respective chronologies (see also Figure 6-9).

A precession maximum in the Southern Hemisphere, used to time the beginning of climate change from an interglacial toward a glacial climate, occurred 399,000 years ago during OIS 11 (Berger and Loutre 1991 [DIRS 108910], DTN: GS000200005121.001 [DIRS 146818]). The first data point in the Devils Hole record (Landwehr et al. 1997 [DIRS 109124], DTN: GS000200005121.003 [DIRS 146819]) indicating climate change away from the OIS 11 interglacial climate occurs at 397,300 years ago (ignoring the Devils Hole age standard deviation) or 1,700 years after the precession maximum. A precession maximum in the Southern Hemisphere during the present interglacial climate occurred 1,000 years ago (Figure 6-8). Using the OIS 11/10 timing indicates the beginning of climate change away from the present interglacial may be about 700 years in the future.

Placement of a past/present point in the Owens Lake sedimentary record requires that the sedimentary chronology be placed in the context of the Devils Hole chronology. An Owens Lake chronology must be based on a sediment mass-accumulation and by correlation with the chronology of the Devils Hole $\delta^{18} \mathrm{O}$ record (Landwehr et al. 1997 [DIRS 109124], DTN: GS000200005121.003 [DIRS 146819]), the Owens Lake OIS periods are given an absolute chronology. The correlation between the Owens Lake record and Devils Hole does place the approximate position of the transition between OIS 11/10 in the Owens Lake record in Devils Hole terms. Placement of the Owens Lake sedimentary record in the Devils Hole chronology, unfortunately, only approximates where the past/present point belongs. In order to further refine the Owens Lake age estimates, the ostracode and diatom data (DTN: GS031108315121.003 [DIRS 168533], GS030908315121.001 [DIRS 171152], GS031108315121.002 [DIRS 170227]) in the Owens Lake record are used to identify environmental change during and from the OIS 11 interglacial, and then from the sequence of environmental change, to estimate where the past/present point belongs. The interpretation of this ostracode sequence (Section 6.5) indicates a transition from a full and spilling lake during a glacial or glacial-transition climate (C. caudata) to an intermediate climate between glacial and interglacial (L. ceriotuberosa), to an interglacial climate (L. sappaensis).

The Owens Lake record for the OIS 10 to 11 periods are present in Figure 6-15. OIS 10 is dated at approximately 400-340 $\mathrm{Ka}$ and OIS 11 at about 400-440 Ka (CRWMS M\&O 1998 [DIRS 100127] Table 4-2.1 and Figure 6-3). In order to provide more detailed ages in the Owens Lake record, an average sedimentation rate provided in the scientific literature for this data set of $63 \mathrm{~cm} / \mathrm{ka}$ is used (Litwin et al. 1999 [DIRS 109440]). During OIS 11 the abundance peaks of Limnocythere sappaensis (Owens Lake) are followed by abundant Limnocythere bradburyi (Owens Lake), GS031108315121.003 [DIRS 168533]). L. bradburyi does not occur in the Owens Lake record at the transition into the present interglacial, but was very common in several basins from the southwest, such as the San Agustin Basin ["San Agustin Plains, New Mexico: Age and Paleoenvironmental Potential Reassessed" (Markgraf et al. 1984 [DIRS 109442])]. The appearance of L. bradburyi indicates a period of intense summer monsoon activity (Figure 6-15). 
Presuming that climate is cyclic, then the past/present day point in the OIS 11 sequence at Owens Lake is above the large L. sappaensis abundance peak (labeled 220.0), but below the L. bradburyi peaks (Figure 6-15). The argument is that the large L. sappaensis abundance peak in OIS 11 reflects a mid-stage warm, dry climate and the enhanced monsoon reflecting the L. bradburyi abundance peak has yet to occur in OIS 1. Because the present interglacial is nearing its end, the present-day climate state should be close to the proposed monsoon. Accordingly, the past/present point was placed closer to the monsoon climate indicator. Comparison of the diatom record from OIS 11 and 1 (DTN: GS030908315121.001 [DIRS 171152], GS031108315121.002 [DIRS 170227]) leads to a similar conclusion as that derived from the ostracode data.

From the past/present point at Owens Lake, the timing of the climate change intervals is forecast on the basis of the abundance intervals for the ostracode species (DTN: GS031108315121.003 [DIRS 168533]). The time between the sample in the L. sappaensis abundance peak and the first appearance of $L$. bradburyi is about 600 years in Owens Lake time, the length of present-daylike climate remaining before the enhanced monsoon climate begins (Table 6-1). In turn, the length of the L. bradburyi interval of monsoon climate is about 1,400 years in Owens Lake time (this includes the interval above L. bradburyi containing abundant L. sappaensis) (Figure 6-15). The monsoon interval is followed by more than 8,000 years of glacial-transition climate represented by the Candona caudata interval, thus completing the 10,000 years for the future climate analog (Figure 6-15).

The timing of the climate episodes noted above are based on the Owens Lake sediment mass-accumulation curve that was derived for the entire core. As discussed above the mass-accumulation curve gives an average chronology at best and in many places in the core the average accumulation rate of sediment may not be a good indicator of elapsed time. The average sediment-accumulation rate is about $40 \mathrm{~cm}$ per 1,000 years (Smith and Bischoff, 1997 [DIRS 109480]) based on a 6- to 304-m (20- to 1,000-ft) section of the Owens Lake borehole OL-92, and is the basis for the times listed in the paragraph above and in Figure 6-15.

"Calibrating Late Quaternary Terrestrial Climate Signals: Radiometrically Dated Pollen Evidence from the Southern Sierra Nevada, USA" (Litwin et al. 1999 [DIRS 109440]), which focuses on the upper part of the core, suggests that the sediment accumulation rates during dry climate periods are much higher than during wet climate periods. In Litwin et al. (1999 [DIRS 109440]) they estimate accumulation rates for interglacial, glacial, and transitions between interglacial and glacial climates. The future climate analog (OIS 11/10) deals with interglacial and glacial-transition climates. However, the part of the core that should be considered in terms of different accumulation rates is the interglacial, as the glacial-transition climates extend well beyond the 10,000-year limit discussed here. Litwin et al. (1999 [DIRS 109440]) estimate that interglacial climate sediment accumulation rates from OIS 1 and 5 are 60 and $66 \mathrm{~cm}$ per 1,000 years, respectively. These values provide an alternative accumulation rate for the interglacial periods in Owens Lake to the approximately $40 \mathrm{~cm}$ per 1,000 years mass-accumulation rate for the entire record. The Smith and Bischoff (1997 [DIRS 109480]) study also presents a sediment-accumulation rate for the upper (younger) $6-\mathrm{m}$ to $24-\mathrm{m}$ (20- to 79-ft) section of the borehole that indicated a sediment-accumulation rate of $79 \mathrm{~cm}$ per thousand years. Interestingly, the 6- to $24-\mathrm{m}$ borehole interval is dominated by the last glacial interval. Correcting for differences in porosity and density, both the 6- to 24-m (20- to 79-ft) 
interval and the 6- to $304-\mathrm{m}$ (20- to 1,000-ft) interval had nearly identical mass-accumulation rates $\left(52.4\right.$ and $51.4 \mathrm{~g} / \mathrm{cm}^{2}$ per thousand years). This indicates that the greater sedimentaccumulation rate of the 6- to 24-m (20- to 79-ft) interval was due to less compaction. In their study of borehole OL-92 core, Liwin et al. (1999 [DIRS 109440]) found that, although a Holocene age section of silt had a sediment-accumulation rate of $64 \mathrm{~cm}$ per thousand years, the mass-accumulation rate was $42.6 \mathrm{~g} / \mathrm{cm}^{2}$ per thousand year, less than the average massaccumulation rate derived by Smith and Bischoff (1997 [DIRS 109480]). The data indicate that sediment-accumulation rates need to be corrected (normalized) for the impact of compaction and that the sediment-accumulation rates of 60 and $66 \mathrm{~cm}$ per thousand years may need to be adjusted. Because the 6- to 304-m (20- to 1,000-ft) borehole interval accounts for much of the compaction forces (by nature of its length) the $40 \mathrm{~cm}$ per thousand year average sedimentaccumulation rate is likely the most representative value. 


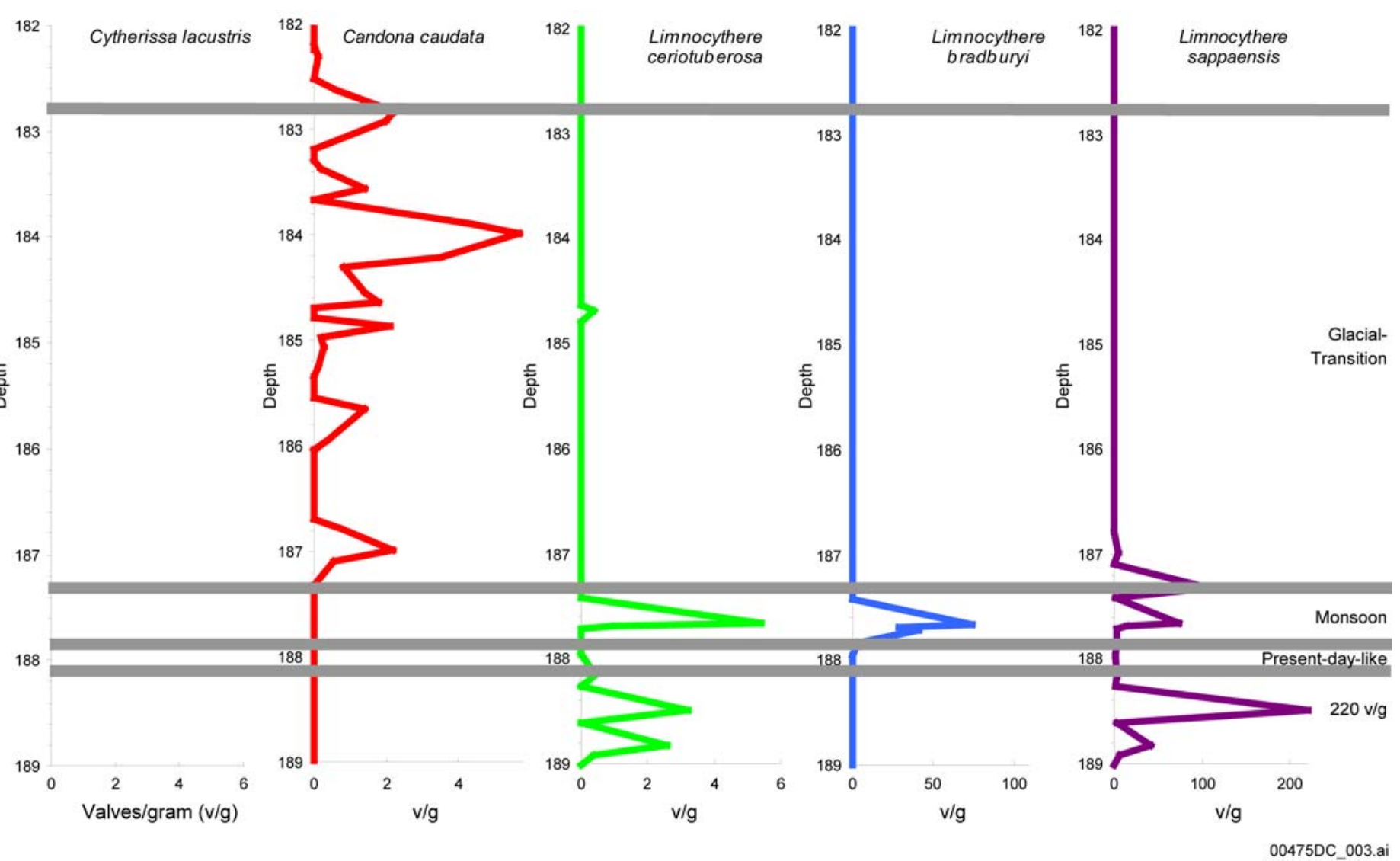

DTN: GS031108315121.003 [DIRS 168533].

NOTE: Data presented are for the OIS 10 and 11 periods corresponding to the forecasted next 10,000 years.

Figure 6-15. Stratigraphic Distribution of Ostracodes in Part of the Owens Lake Record Used for the Future Climate Analog 
The sediment accumulation rates for interglacial climates noted above average about $63 \mathrm{~cm}$ per 1,000 years. There is no way of knowing if the OIS 11 interglacial had a similar sediment accumulation rate, but given that the rates for OIS 5 and 1 are similar, it is reasonable to assume such a rate might apply to OIS 11 . If the higher rate of sediment accumulation does apply, then the timing of climate change derived from it is more probable than that derived from a uniform rate of sediment accumulation. Applying a rate of $63 \mathrm{~cm}$ of sediment accumulation per 1,000 years to OIS 11 results (Figure 6-15) in an alternative timing for the three climate states. Therefore, the age relative to age for the previous depth is calculated by multiplying the depth by the inverse of the sedimentation rate in meters per year $(1 /(0.63$ present-day-like depth of 188.05 (Figure 6-15) on monsoon depth of 187.8 (Figure 6-15).

- Present-day-like for about 397 years, rounded to 400 years,

- Monsoon for about 873 years, rounded to 900 years, and

- Glacial transition for about 8,700 years (10,000 minus 400 minus 900).

A present-day-like or warmer than present-day-like climate for about 1,300 years before entering a glacial-transition climate is similar to the estimate previously discussed (700 years) based on a comparison of precession and the Devils Hole record. It is also similar to Imbrie and Imbrie's estimate (1986 [DIRS 109117], p. 183-184) that earth's climate should become progressively warmer for about the next 1,000 years due to an increase in solar output, and then begin to cool due to Milankovitch forcing discussed in Section 6.4 and Figure 6-4.

Calculating the timing estimates again for the $40 \mathrm{~cm} / \mathrm{kyr}$ estimated average sedimentation rate (Litwin et al. 1999 [DIRS 109440]) provides a range for the following forecast for timing of climate changes. A present-day-like climate should persist for about 400 to 600 years after present. The present-day-like climate will be followed by a monsoon climate that will last from about 900 to 1,400 years after present and that climate will be followed by a glacial-transition climate that will persist through the remainder of the 10,000-year period at Yucca Mountain.

Table 6-1. Meteorological Stations Selected to Represent Future Climate States at Yucca Mountain, Nevada

\begin{tabular}{|c|c|c|c|c|}
\hline $\begin{array}{l}\text { Climate } \\
\text { State }\end{array}$ & Duration & $\begin{array}{c}\text { Representative } \\
\text { Meteorological } \\
\text { Stations } \\
\end{array}$ & \multicolumn{2}{|c|}{$\begin{array}{c}\text { Locations of } \\
\text { Meteorological Stations }\end{array}$} \\
\hline $\begin{array}{l}\text { Present-day } \\
\text { Interglacial } \\
\text { Climate }\end{array}$ & 400 to 600 years & $\begin{array}{c}\text { Site and regional } \\
\text { meteorological stations }\end{array}$ & \multicolumn{2}{|c|}{ Yucca Mountain region } \\
\hline \multirow{2}{*}{$\begin{array}{l}\text { Monsoon } \\
\text { Climate }\end{array}$} & \multirow{2}{*}{$\begin{array}{c}900 \text { to } 1,400 \\
\text { Years }\end{array}$} & $\begin{array}{c}\text { Average Upper Bound: } \\
\text { Nogales, Arizona } \\
\text { Hobbs, New Mexico }\end{array}$ & $\begin{array}{r}\text { North Latitude } \\
31^{\circ} 21^{\prime} \\
32^{\circ} 42^{\prime} \\
\end{array}$ & $\begin{array}{l}\text { West Longitude } \\
\qquad \begin{array}{c}110^{\circ} 55^{\prime} \\
103^{\circ} 08^{\prime}\end{array}\end{array}$ \\
\hline & & $\begin{array}{l}\text { Average Lower Bound: } \\
\text { Site and regional } \\
\text { meteorological stations }\end{array}$ & \multicolumn{2}{|c|}{ Yucca Mountain region } \\
\hline
\end{tabular}


Table 6-1. Meteorological Stations Selected to Represent Future Climate States at Yucca Mountain, Nevada (Continued)

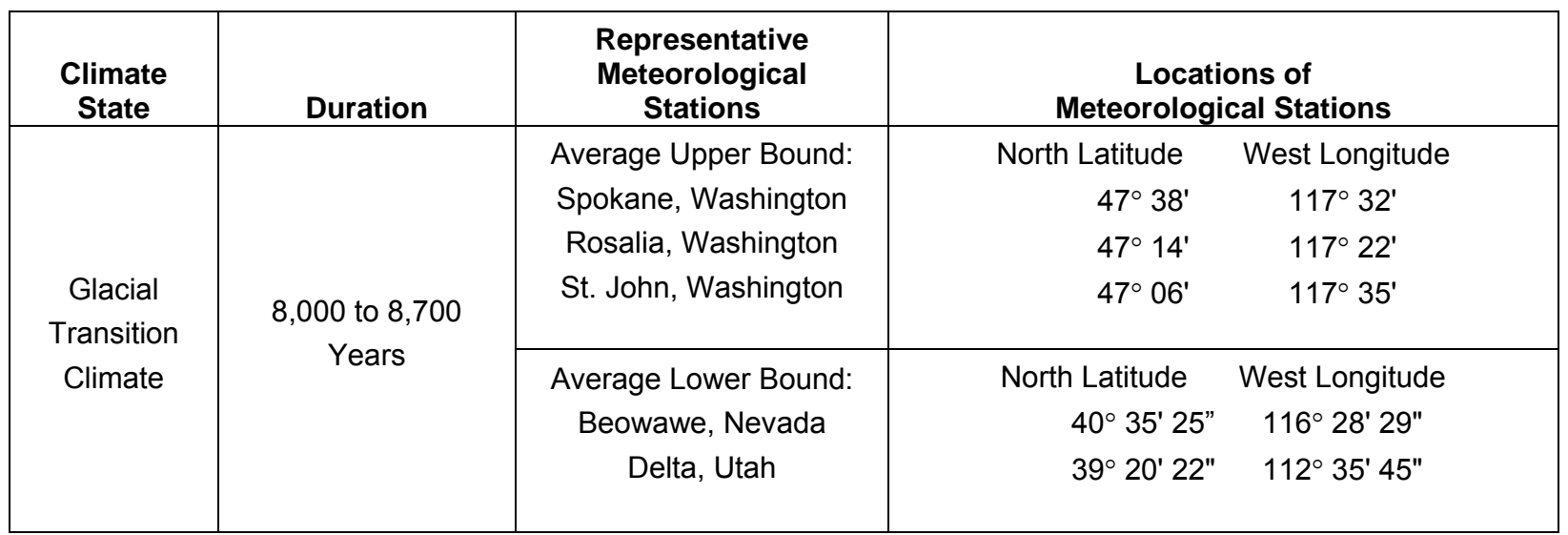

NOTE: Selection of representative meteorological station locations is discussed in Section 6.6.2.

Other factors that may impact the timing of the three climate states include the standard deviation associated with the Devils Hole ages, the uncertainty of the exact time when the Devils Hole record implies climate is changing, the uncertainty of exactly where the past/present point is in the Owens Lake record (analog climate proxy record), and the uncertainty of climate change itself. The standard deviations about the mean of the Devils Hole ages are, by their nature, an estimate of uncertainty. That estimate was not incorporated into the analysis, in part, because the other sources of uncertainty can not be estimated and hence their relation to standard deviation is unknown. Transitions between climate states similar to those in Table 6-1 have been found in Future Climate Analysis-10,000 Years to 1,000,000 Years After Present (Sharpe 2003 [DIRS 161591]).

The uncertainty of the exact time when the Devils Hole record is beginning to change implies climate has two components. The first component involves the uncertainty of knowing if the beginning of a change in the isotope values in the recharge area are directly correlated with changes in MAP and MAT or other climate parameters. There could be a lead or a lag between change in regional climate parameters and a record of recharge at Devils Hole. The second component involves the nature of the Devils Hole samples themselves. Each sample integrates a particular thickness of carbonate in a continuous sample series and represents about 1,800 years (Winograd et al. 1992 [DIRS 100094]). Consequently, any rapid change in the recharge recorded at Devils Hole could occur anytime within the 1,800 years.

Placement of the past/present point in the Owens Lake record is a matter of interpretation, and has an unknown level of uncertainty associated with it. Because this uncertainty could be large or small it may compound or limit the effects from obtaining time from the estimates of sediment accumulation.

The final source of uncertainty comes from the chaotic nature of the climate system itself ["Climate Change Science is Now Big Science" (Stanhill 1999 [DIRS 122197])]. The climate proxy records throughout the Owens Lake cores show various degrees of variability that may well reflect decade- or century-scale variability that may or may not have significance to the 
timing of climate change on the multi-century or millennia time scales. If climate is wholly chaotic, then it might not be totally cyclic and so the past might not provide a basis to understand the details of future climates.

The above sources of uncertainty could sum together to create a large uncertainty or could cancel each other out so as to create a smaller uncertainty. Unlike the different estimates of sediment accumulation rates, there is no simple or objective way of assessing the nature of the above four sources of uncertainty as it might apply to the future.

\subsubsection{The Nature of Future Climate Change}

The nature or characteristics of future climate, but especially the annual and seasonal characteristics of precipitation and temperature, provide the input terms to the infiltration model (BSC 2004 [DIRS 170007]) whose output feeds the unsaturated zone flow model. The nature of future climate, as discussed below, is forecast in terms of an upper bound and a lower bound. Upper- and lower-bound values are given here because: 1) they are needed for the models and 2) given the numerous uncertainties (Sections 6.3, 6.4, and 6.5) in the record of turning climate proxy data into climate values, establishing possible bounds is more defensible than establishing means, especially means that are applied to long periods of time. Because the infiltration model (BSC 2004 [DIRS 170007]) requires annual and seasonal climate values to run properly, the upper- and lower-bound values are established with meteorological stations, selected as representative of the climate. Stations with complete and long records were given priority.

The past climate history proposed as the timing for the future climate analog (Section 6.6.1) is composed of three climates, each characterized by particular species assemblages of ostracodes (DTN: GS031108315121.003 [DIRS 168533]). When necessary, the ostracode assemblage interpretations are supported by interpretations of the diatom assemblages (DTN: GS030908315121.001 [DIRS 171152], GS031108315121.002 [DIRS 170227]). The present-day-like climate interval is characterized by Limnocythere sappaensis and is forecast to persist for the next 400 to 600 years. The second climate interval is characterized by a mixture of $L$. bradburyi and $L$. sappaensis and is forecast to persist for about 900 to 1,400 years after the first climate interval. The third and last climate interval is characterized by Candona caudata as well as rare occurrences of L. sappaensis. The third climate interval also is characterized by the diatom Stephanodiscus asteroides, and diatom species belonging to Campylodiscus spp. and Anomoeneis spp., based on the data collected by J. Platt Bradbury (DTN: GS030908315121.001 [DIRS 171152], GS031108315121.002 [DIRS 170227]), and is forecast to persist for the remainder of the 10,000-year period.

The present-day-like climate interval is an interval of time when Owens Lake was supported by groundwater discharge, and an Owens River that was predominately at base flow. Summers are warm to hot and very evaporative with evaporation greatly exceeding precipitation at low elevation. Snowpack at high elevation is typically low to moderate, because the polar front does not remain fixed at a southerly position during the winter, and so does not set up a storm wave train that moves Pacific moisture over the Sierra Nevada Mountains (see discussion in Section 6.2). Consequently with low snowpack, surface-water flow in the Owens River is usually low and seasonal. Owens Lake remains saline and at a low lake level for long periods of 
time. Precipitation, whether as rain or snow, is typically recycled to the atmosphere by evaporation or used by the local vegetation.

The wettest years, which represent the upper-bound moisture regimes during present-day climate, will typically be years when Pacific air flow is focused toward the high Sierra Mountains, increasing snowpack and hence the seasonal duration of surface-water flow in the Owens River and its potential to dilute or flush Owens Lake, thus diluting the salt content. Such climates also focus Pacific moisture toward southern Nevada, such as the El Nino climates that have been common during the last couple of decades. Dry years, which represent the lower-bound moisture regimes during present-day climate, will be those years with minimal winter precipitation, typically years when the polar front remains largely north of the region and summer precipitation is dominated by subtropical high activity, but not to the degree necessary to generate a monsoon-type climate.

Meteorological data for the upper and lower bounds come from available stations in the region, including Yucca Mountain Project and non-project data (see Figure 6-16, Table 6-1) (BSC 2004 [DIRS 170007]). Regional averaged meteorological data from the National Oceanic and Atmospheric Administration reported by Thompson et al. (1999 [DIRS 109470], Figures 16 and 17) indicate that areas largely north of Yucca Mountain within central Nevada have had a range of MAP from about $75 \mathrm{~mm}$ to one value as high as $360 \mathrm{~mm}$ for the period of record (about 100 years). Similarly, from the same data sets, areas largely south of Yucca Mountain have had a range of MAP from less than $50 \mathrm{~mm}$ to one value as high as $325 \mathrm{~mm}$ for the period of record. Notably, there are more low values than extremely high values, that is, the typical value is in the lower half of the range. By contrast, MAT in both regions falls into a smaller range of about $4^{\circ} \mathrm{C}$, or about $16^{\circ} \mathrm{C}$ to $20^{\circ} \mathrm{C}$ for the area south of Yucca Mountain and about $8^{\circ} \mathrm{C}$ to $12^{\circ} \mathrm{C}$ for the area north of Yucca Mountain (Thompson et al. 1999 [DIRS 109470], Figures 16 and 17).

Because climate is a regional phenomenon and climate is the primary driver of hydrology, the climate that creates the environmental characteristics defined above for Owens Lake also must be more or less the climate that exists at Yucca Mountain. Therefore, a hot and dry climate at Yucca Mountain is consistent with a saline Owens Lake supported largely by base flow. Owens Lake hydrology therefore is a direct proxy for climate at Yucca Mountain.

The second climate interval, the monsoon climate, is characterized in the Owens Lake record by a mixture of Limnocythere bradburyi and L. sappaensis (DTN: GS031108315121.003 [DIRS 168533]). Because L. bradburyi has a lower salinity tolerance than L. sappaensis (Forester 1983 [DIRS 109023]; Forester 1985 [DIRS 109423]) and does not appear to be tolerant of cold winters (Smith and Forester 1994 [DIRS 109456]), its existence in Owens Lake must imply a relatively lower TDS (less than about $10,000 \mathrm{mg} / \mathrm{L}$ ) and a source water derived from something other than snow melt. Surface flow derived from snow melt itself probably is not a problem for L. bradburyi, but rather the cold winter climates that generate the snowpack are a problem for this species. The hydrology of Owens Lake is strongly linked to winter precipitation and hence dilute deeper lakes are due to seasonal to annual flow derived from snowpack (see Section 6.5). From Figures 12 and 13 as well as discussion in Section 6.5, an expansion and intensification of the summer rain system, that is a stronger monsoon sufficient to generate diluting surface flow in the Owens River, is the simplest way to explain the occurrence of this species. The diatoms that occur during the L. bradburyi interval include saline planktic species, 
implying the lake is deeper, and less alkaline during this period. The diatom paleoenvironment is consistent with that implied by L. bradburyi.

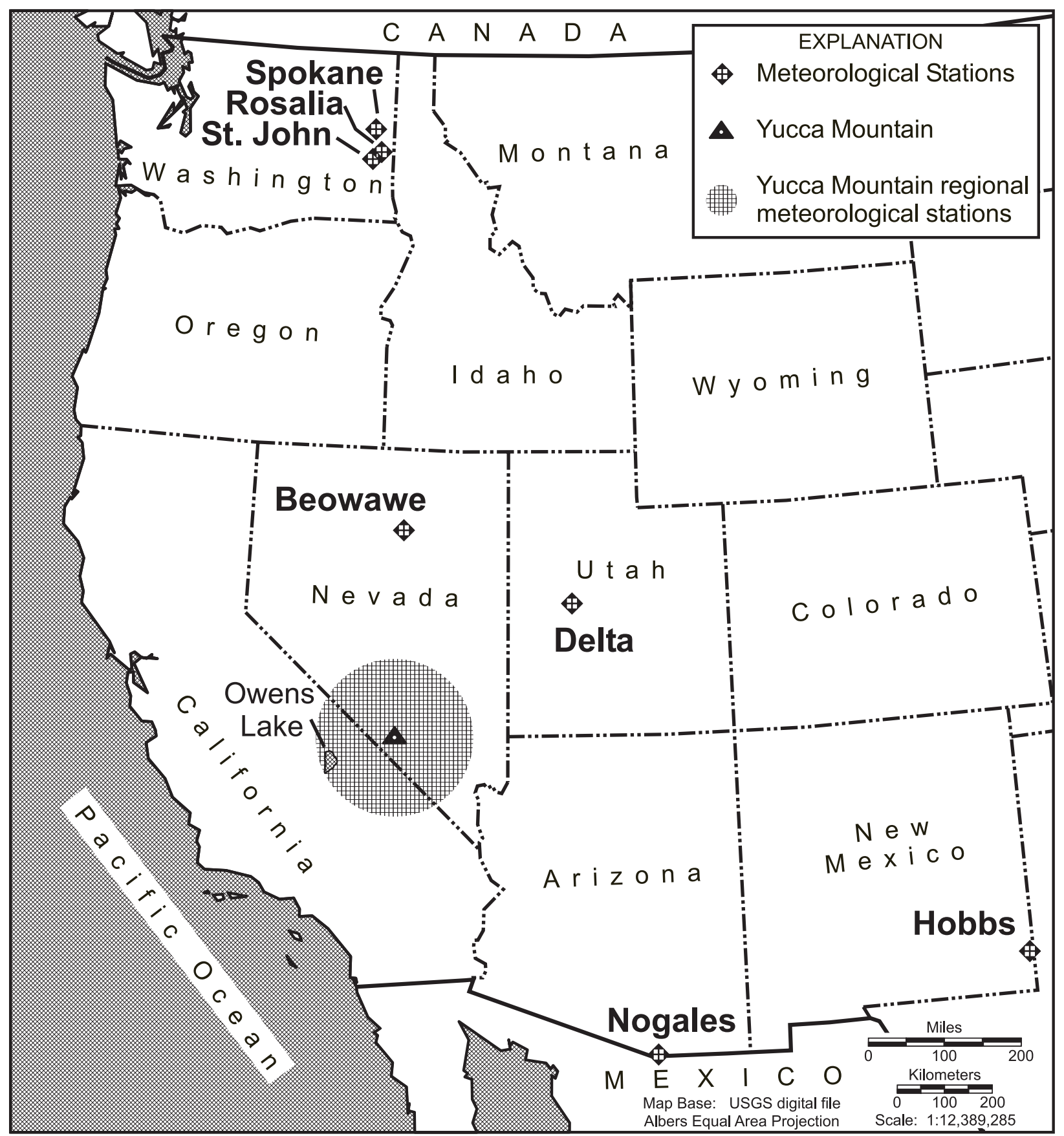

Figure 6-16. Meteorological Stations Selected (Table 6-1) to Represent Future Climate States at Yucca Mountain, Nevada 
Accordingly, an analog meteorological station(s) for the L. bradburyi monsoon climate must be found to the south of Owens Lake today in either Mexico or the southernmost U.S. An analog from either Mexico or the southernmost U.S. would fulfill the taxon's temperature requirements and identify sites whose primary precipitation falls in the summer season. The level of precipitation has to be higher than present-day Owens Lake MAP in order to maintain a lower salinity lake that is supported largely by summer precipitation within the present-day warm evaporation regime. Summer rain and associated cloud cover would tend to lower evaporation relative to today. Historic records of MAP from Haiwee Reservoir $11 \mathrm{~km}$ south of Owens Lake show that summer rain dominated the annual precipitation during the years 1963, 1976, and 1977, with MAP levels amounting to $270 \mathrm{~mm}, 251 \mathrm{~mm}$, and $208 \mathrm{~mm}$ respectively [Climatological Data Volume 67, No.13, California Annual Summary 1963 (U.S. Department of Commerce 1964 [DIRS 109414]); Climatological Data. Volume 80, No.13, California Annual Summary 1976 (U.S. Department of Commerce, National Oceanic and Atmospheric Administration 1977 [DIRS 109417]); Climatological Data. Volume 81, No.13 California Annual Summary 1977 (U.S. Department of Commerce, National Oceanic and Atmospheric Administration 1978 [DIRS 109418])]. During those years flow in the Owens River was minimal, (CRWMS M\&O 1998 [DIRS 100127], Figure 4.2-15). Therefore, those levels of MAP were not sufficient to create the deeper and slightly saline lake that the ostracode and diatom proxies imply existed during the monsoon climate.

Considering the above climate conditions, the available meteorological data, and the region in which Limnocythere bradburyi occurs now, the station closest to the occurrence of the taxon in the U.S. is the one at Lordsburg, New Mexico with an MAP of $284 \mathrm{~mm}$ (DTN: GS000100001221.001 [DIRS 146816]). An MAP value of only $284 \mathrm{~mm}$ per year at Lordsburg is sufficient only to support an ephemeral playa and from the Haiwee Reservoir meteorological data above is less than values that resulted in limited flow in the Owens River. Sites in central Mexico where the taxon lives commonly have MAP values above $500 \mathrm{~mm}$ and as high as 2,000 $\mathrm{mm}$ (Forester 1985 [DIRS 109423]). Remarkably, despite the latter very high levels of MAP, the Mexican lakes in which the taxon lives are typically shallow, if not ephemeral, and slightly saline, reflecting the very high levels of evaporation. Presumably the L. bradburyi regions in central Mexico would be poor analogs for Owens Lake, because these lower latitude sites have a much higher solar input, thus creating a different climate-lake evaporation regime than would have existed at Owens Lake in the past.

Selection of a monsoon climate analog site(s) must then come from the southern United States. An upper-bound value for the monsoon climate presumably must be a higher value than any of the values from Haiwee Reservoir, and MAT must remain as high or higher than Owens Lake today. Within the region in the U.S. that experiences a strong summer monsoon and where Limnocythere bradburyi lives, there are two meteorological stations with long, complete records that have consistently higher levels of MAP than Haiwee Reservoir: the station at Hobbs, New Mexico and the station at Nogales, Arizona, with MAP levels of $418 \mathrm{~mm}$ and $414 \mathrm{~mm}$, respectively (DTN: GS000100001221.001 [DIRS 146816]). Two stations are selected to minimize the influence of local meteorological phenomena on the input to the infiltration model (BSC 2004 [DIRS 170007]) (Figure 6-16, Table 6-1). The MAP at these sites may not be high enough to generate the appropriate lake in the Owens Basin, but within the available present-day meteorological data, these are the best choices available. Because Limnocythere sappaensis exists throughout the climate interval and at some horizons is the only ostracode 
(DTN: GS031108315121.003 [DIRS 168533]), the conditions at Yucca Mountain today are representative of the dry lower bound for the monsoon climate. The meteorological stations selected for the lower bound for the monsoon climate are those from the Yucca Mountain region today (BSC 2004 [DIRS 170007]).

The monsoon climate, from the analogs, is a climate where winter precipitation exists, but does not dominate MAP. The lesser importance of winter precipitation means that winter air masses are also of less importance, and thus the winter season is likely warmer than today and hence more evaporative. The annual transition from the winter season to the wet summer season would be hot and dry as is true of most seasonal transitions to a monsoon climate. Summer rain would then expand northward either due to a monsoon land-to-ocean circulation or to the northward migration of the subtropical easterlies, that is, the trades. Intense summer rain, unlike today, would be sufficient to sustain flow into Owens Lake to maintain a moderate-sized and slightly saline lake at least on a seasonal basis. Climate during this period would vary from episodes of intense summer rain to present-day-like climates with relatively more winter and less summer precipitation. The intense summer rain periods would necessarily be periods with extensive cloud cover whereas summers with lesser rain and winter seasons would have limited cloud cover.

An expansion of the summer rain regime to the Owens Basin region also would have expanded well north of Yucca Mountain (Figure 6-14). Because Yucca Mountain would be more centrally located within such a summer rain regime it may experience upper-bound levels of MAP that are higher than those identified above from the analog meteorological stations.

The third climate, the glacial-transition climate, is characterized by the appearance of Candona caudata (DTN: GS031108315121.003 [DIRS 168533]) as well as by the diatom Stephanodiscus asteroides, and diatom species belonging to Campylodiscus spp. and Anomoeneis spp. (DTN: GS030908315121.001 [DIRS 171152], GS031108315121.002 [DIRS 170227]). The change from the monsoon climate to the glacial-transition climate is rapid, assuming no unconformities in the Owens Lake record, occurring within 100 to 200 years (Smith and Bischoff 1997 [DIRS 109480]). The magnitude of the climate change was as large as it was fast, shifting from a strong monsoon system dominated by summer precipitation to a winter regime with sufficient effective moisture to sustain a fresh and spilling Owens Lake.

Candona caudata lives in the Owens Lake area today as well as in many places north of Owens Lake including sites within Canada and Alaska. In the Owens Lake area it lives in the Owens River as well as in freshwater lakes at higher elevation, and thus is tolerant of the region's seasonal temperature variability, but is not tolerant of saline water that would be typical for Owens Lake today under natural conditions. Candona caudata only enters Owens Lake when the TDS falls and remains below about 3,000 mg/L (Bradbury et al. 1989 [DIRS 109413]), and that typically implies the lake is full and spilling. The presence of Stephanodiscus asteroides, a cool and freshwater planktic diatom (DTN: GS030908315121.001 [DIRS 171152], GS031108315121.002 [DIRS 170227]), also implies a deep spilling lake. Conversely, the sporadic appearance of Limnocythere sappaensis (DTN: GS031108315121.003 [DIRS 168533]) as well as the diatoms Campylodiscus spp. and Anomoeneis spp. imply there were also episodes during this climate period that were relatively warm and dry, thus demonstrating some degree of climate variability. 
As described above (Section 6.5), for the lake to be full and spilling the polar front must be resident in the region during much of the winter, both lowering MAT and hence evaporation, and increasing snowpack, and hence surface flow to the lake. The genesis of greater snowpack with a resident polar air mass must also lower MAT and increase MAP at Yucca Mountain. The cooler climate, however, never becomes very cold with a high effective moisture as was true of the last two full-glacial periods. The ostracodes and diatoms implying warm dry climates do not persist throughout the Owens Lake record thus indicating the warmth is not seasonal summer warmth, as is true of the present-day climate, but rather represents warm episodes within a generally cool and wet period. The climate during the glacial-transition period was typically a cool, usually wet winter season with warm (but not hot) to cool summers that were usually dry relative to the present-day summers.

Selecting upper- and lower-bound meteorological stations for the glacial-transition climate must identify sites with cool winter wet seasons, and warm to cool and dry summers, so areas north of the summer rain regime shown in Figure 6-14. Further, if possible, the analog sites should lie on the east side of large mountain ranges, and hence in the rain shadow of those ranges. The absence of Cytherissa lacustris, (DTN: GS031108315121.003 [DIRS 168533]) the ostracode implying cold Canadian-like climate, implies the upper-bound analog lies within the contiguous U.S.

The analog station(s) presumably should be areas with some or all of the common ostracodes and diatoms found in Owens Lake (DTN: GS031108315121.003 [DIRS 168533], GS030908315121.001 [DIRS 171152], GS031108315121.002 [DIRS 170227]), thus potentially integrating the biology, hydrology, and climate linkages that were expressed in the past at Owens Lake. The study by Thompson et al. (1999 [DIRS 109470]) suggests the MAT at Yucca Mountain during the last full-glacial period was about $8^{\circ} \mathrm{C}$ and during that period Cytherissa lacustris was common in Owens Lake. Thus, the MAT for the glacial-transition climate should be no colder than and preferably warmer than $8^{\circ} \mathrm{C}$. Finally, the analog station(s) should be in the semi-arid west, because, although the glacial-transition climate is wetter and cooler than the interglacial climates, effective moisture is still negative, as is true for all of the glacial and glacial-transition climates at Owens Lake and Yucca Mountain.

The meteorological station(s) representing the glacial transition upper bound should be in a place with a higher MAP than periods of high Owens Lake discharge derived from winter precipitation during the historic period. One of the highest discharge years for the Owens River (CRWMS M\&O 1998 [DIRS 100127], Figure 4.2-15) was in 1969 and the MAP at Haiwee, just south of Owens Lake, was 309 mm [Climatological Data. Volume 73, No. 13, California Annual Summary 1969 (U.S. Department of Commerce 1970 [DIRS 109416])]. Surface flow in the Owens River is primarily influenced by snowpack in the Sierra Mountains, not by high winter MAP near Owens Lake, unlike times of high summer MAP when surface flow is dominated by summer rain. Nonetheless, high snowpack years also correspond to high MAP from winter precipitation at Owens Lake (Forester et al. 1999 [DIRS 109425]; CRWMS M\&O 1998 [DIRS 100127], p. 4.2-16 to 4.2-18). Accordingly, the upper-bound meteorological site(s) should have higher MAP than $309 \mathrm{~mm}$, because even the high historic discharge levels are not sufficient to fill and spill the lake as implied by the diatoms and ostracodes. Because the fill and spill of Owens Lake is believed to be related to the seasonal, if not the annual, residence of the polar front (see Section 6.2), then the upper-bound meteorological station should logically be 
selected in an area where in today's climate the polar front resides through most or all of the winter season and where its average position resides most of the year.

Given all of the above qualifying conditions (Spokane, Rosalia, and St. John, Washington), the upper-bound glacial-transition meteorological site is selected in the northwestern United States east of the Cascades for several reasons. The region lies east of a high mountain range, and thus falls within a rain shadow, as does Yucca Mountain. The regional MAP is winter-precipitation dominated, and is under the influence of the polar front during the winter as well as being situated near the average position of the polar front throughout the year. Furthermore, unlike localities farther north in Canada, the region does not experience extended dominance by the very cold Arctic high-pressure air, typical of the cold, full-glacial periods. A number of meteorological stations in the region have MAP values well above $300 \mathrm{~mm}$ (U.S. Department of Commerce 1970 [DIRS 109416]), which in today's temperature regime in the Owens Basin only supports a saline lake. The regional values of MAT are on the cool side, but several stations are above the $8^{\circ} \mathrm{C}$ values considered to be a lower limit for the glacial-transition climate (Thompson et al. 1999 [DIRS 109470]). The diatoms and ostracodes common to the glacial-transition interval in Owens Lake are known to live in lakes in the region such as Sprague Lake, Washington. Thus lakes in the region contain a common biology, hydrology, and climate linkage with the paleolake in the Owens Basin.

Examination of the meteorological station data from eastern Washington (DTN: GS000100001221.001 [DIRS 146816]) both in the context of the above considerations and in terms of length and completeness of record provides three stations that fit all of the criteria for the upper-bound glacial-transition climate (see Figure 6-16, and Table 6-1). The stations, Spokane, Rosalia, and St. John, are all close to each other, but do not have identical records, presumably reflecting local differences in MAP and MAT. As in other cases, selecting multiple meteorological stations is intended to minimize local effects on the climate parameters used as input to the infiltration model (BSC 2004 [DIRS 170007]).

The meteorological stations representing the lower-bound glacial-transition climate should be in a place where MAT is higher than the upper bound and thus most will be south of the upper-bound localities. The MAT should, however, be lower than that for the Owens Lake Basin today so that effective moisture levels are higher consistent with a fill and spill lake. The stations should have a lower MAP than the upper-bound sites, because the record from the Owens Lake Basin shows episodes when either saline diatoms or ostracodes or both are present implying less surface flow in the Owens River. The absence, however, of abundant saline taxa implies effective moisture is higher than present-day and that likely reflects cooler than presentday MAT values rather than high MAP values. Therefore, the lower-bound meteorological sites may have MAP values that are similar to or even lower than present-day Owens Lake Basin. As with the upper-bound meteorological sites, the region should be winter precipitation dominated, should be north of the summer rain regime (Figure 6-14), and have some or all of the ostracode or diatom species found in the fossil record at Owens Lake.

Inspection of meteorological sites that fit these conditions reveals that there are few choices available. The one set of meteorological data that fits all of these criteria and also has a long and complete record is found at Delta, Utah (DTN: GS000100001221.001 [DIRS 146816]), and thus that site is selected as one of the lower-bound sites (Figure 6-16, Table 6-1). The site at 
Beowawe, Nevada (DTN: GS000100001221.001 [DIRS 146816]), was added as a lower-bound meteorological station, again to avoid the potential of using a single site for input into the infiltration model (BSC 2004 [DIRS 170007]) (Figure 6-16, Table 6-1), because its meteorological data meet most of the requirements noted above.

The upper-bound MAP values for the monsoon and the glacial-transition climates are only slightly higher than the present-day high values from the region. Thompson et al. (1999 [DIRS 109470]) show the National Oceanic and Atmospheric Administration data for region 3, generally north of Yucca Mountain, and region 4, generally south of Yucca Mountain. The latter data show upper-bound values in the mid-300s of mm and numerous values in the low $300 \mathrm{~s}$ of $\mathrm{mm}$. Thus selection of meteorological stations having upper-bound values in the low $400 \mathrm{~s}$ of $\mathrm{mm}$ implies that the future climate states are only somewhat wetter than the present-day climate. The lower-bound MAP value, selected as a future climate analog for the glacial-transition climate, is much higher than the present-day lower-bound values reported for regions 3 and 4 (see Thompson et al. 1999 [DIRS 109470]). Similar to the lower-bound glacial-transition value for MAP, the values of MAT for the glacial-transition analog climate are much lower than the MAT values in the Yucca Mountain and Owens Lake region today (Thompson et al. 1999 [DIRS 109470] and DTN: GS000100001221.001 [DIRS 146816]). Thus the apparent principal differences between the present-day climate and the glacial-transition climate upper and lower bounds are that the latter climates are not as dry nor as warm as present-day, that is, the biggest differences from today are in the lower-bound values, not the upper-bound values. MAT and its impact on evaporation and hence on effective moisture would seem to affect the future climate analog more than gains in MAP.

The results of this future climate analysis in Table 6-1 have been documented in output DTN: GS000308315121.003. This output will be used to estimate net infiltration for different climate states at Yucca Mountain, specifically, precipitation and temperature values based on the analogue sites and evapotranspiration values will be simulated using the Priestley-Taylor equation in Section 6.4.4 in Simulation of Net Infiltration for Present-Day and Potential Future Climates (BSC 2004 [DIRS 170007]). 


\section{INTENTIONALLY LEFT BLANK}




\section{CONCLUSIONS}

\subsection{ANALYSIS CONCLUSIONS}

The analysis of future climate change in this report consists of examining the paleoclimate record in order to find a past climate sequence on which to base extrapolation of future climatic conditions in the Yucca Mountain region. Four key assumptions are discussed:

1. Climate is cyclical over 400,000-year periods base on earth-orbital parameters (Milankovitch forcing) and the earth is at the beginning of the next 400,000-year cycle. Climate cyclicity is important for forecasting future climate because it implies some past climate or aspects of past climate will recur in the future.

2. Climate change can be timed with an earth-orbital clock of precession and eccentricity, so the timing of future climate change can be estimated from the orbital clock (Milankovitch Theory). Timing climate change with a clock that can be set accurately in the future is important for forecasting climate, because it allows for an accurate assessment of future climate durations used as input by TSPA and infiltration (BSC 2004 [DIRS 170007]) models. Cycles of glacial and interglacial climates occur about every 100,000 years.

3. Past glacial/interglacial climates differ from each other, and the nature of particular past climates should repeat themselves in a predetermined order. Thus the analysis can focus on one particular climate sequence rather than all past climates and need not take the conservative approach of using the climates that generate the highest infiltration as being those expected in the next 10,000 years.

4. Long-term earth-based climate-forcing functions, such as tectonic change, have remained relatively constant over the past 500,000 years or so and will remain constant for the next 10,000 or more years. This is important to climate forecasting because such forcing functions change climate in non-cyclic ways, so if they were not constant the first three assumptions would be invalid.

From the discussion of the above four assumptions, which are intended to establish a defensible means for climate forecasting, the Owens Lake climate record is used to describe the climate conditions of the interval selected as the past/future climate analog. The past/future climate analog shows three distinct climates each of which are described in terms of an upper-bound and a lower-bound climate value. The upper and lower bounds of each climate are described from what are believed to be representative analog meteorological stations (Figure 6-16, Table 6-1) and the data at those stations then serve as input to the infiltration model (BSC 2004 [DIRS 170007]). Although other stations might have been selected as more representative of the upper- and lower-bound climate conditions, it is more likely that the way the climate interpretations are used by the infiltration model impacts the amount of infiltration more than differences between particular meteorological stations would impact the amount of infiltration.

The past/future climate analog forecasts that during the next 10,000 years at Yucca Mountain the present-day climate should persist for 400 to 600 years, followed by a warmer and much wetter monsoon climate for 900 to 1,400 years, followed by a cooler and wetter glacial-transition 
climate for the remaining 8,000 to 8,700 years. The range of ages represents uncertainty in the sediment accumulation rates in Owens Lake during the climate analog period.

The upper-bound precipitation values for the monsoon and glacial-transition climates exceed the upper bounds of the region's present-day climate (Thompson et al. 1999 [DIRS 109470], Figures 16 and 17) by about $100 \mathrm{~mm}$. The glacial-transition climate's lower bound exceeds the presentday lower-bound values by about $150 \mathrm{~mm}$ (Section 6.6.2). Thus the future climate based on this method of analysis is wetter, but not substantially wetter than the present-day climate. Temperature, however, defines an important difference between the present-day climate and the glacial-transition climate. The glacial-transition climate is cooler than the present-day climate, so evaporation is substantially lower than during present-day times. A lower level of evaporation means that precipitation will be more readily stored, and hence available for infiltration, than in today's climate.

Forecasting future climate was selected rather than modeling future climate because climate modeling, among many complications, requires that the future climate boundary conditions be known for input to the model. If the future climate boundary conditions were known with confidence, then there would no longer be the need to model climate or the need would be diminished. Because future boundary conditions are not known, a climate model must either use the present-day values or estimates of the future values and in either case, the value of the output from such a model would have limited value in terms of defensibility.

Forecasting the future by using a past climate sequence to bound the future also has many uncertainties, such as 1) differences in the selection of a particular past sequence to forecast the future, 2) the chaotic nature of climate (Stanhill 1999 [DIRS 122197]), and 3) the possibility that human activity may change the climate system in a way that will change the cyclical patterns. Therefore, in this analysis, the rationale for a particular past climate is described, and the method is then applied to acquire possible future climate values. Nonetheless, other arguments can be made for using other past climate sequences as an analog for the next 10,000 years. Like the one presented in this report, these other arguments would have evidence to support them. Uncertainties associated with the potential for forecasting future climates (as discussed in Section 6.6.1) with different past climates is a consequence of the uncertainty of future climate itself, and of the uncertainty associated with depicting future climate by extrapolation of particular past climates into the future. Because there are many past climates that may or may not repeat in the future, and because forecasting is extrapolation, the future climate forecasts given in this report, or any other forecast, must by their very nature have some substantial, but indeterminate, level of uncertainty associated with them.

Uncertainty also exists in data interpretation. In contrast to the future climate analysis documented in this report, Sharpe (2003 [DIRS 161591], p.54) suggests, based on the precession methodology, that the monsoon climate state has already begun. This is about 1,600 years ahead of the future climate estimate reported here. However, the difference in timing between this report and Sharpe (2003 [DIRS 16159]) is considered to be insignificant for two reasons. First, both estimates are based on the Devils Hole record chronology. Each Devils Hole sample integrates an average time interval representing about 1,800 years (Winograd et al. 1992 [DIRS 100094], p.255). Therefore, the difference of 1,600 years is less than the Devils Hole sample resolution of 1,800 years. Second, Sharpe (2003 [DIRS 161591], Table 6-5) reports the timing of 
climate states to the nearest 500 years. Consequently, the two climate analyses are considered generally supportive of each other.

Despite the uncertainties, it is contended that the analysis in this report is reasonable, that it is based on a consistent interpretation of available data, and so is defensible. That is, defensible in the sense that the analysis is based on a body of data and a reasonable possibility rather than that the climate forecast by this analysis is much more likely to occur relative to other possible methods. There are no other uncertainties than those discussed, and there are no limitations on the use of the analysis.

The results of this analysis have been submitted to the Technical Data Management System under output DTN: GS000308315121.003.

\subsection{APPLICABLE ACCEPTANCE CRITERIA}

The following acceptance criteria (AC) summarized in Section 4.2 have been addressed in this report. The AC1 states that 'System Description and Model Integration Are Adequate' and AC2 states that 'Data Are Sufficient for Model Justification' (BSC 2004 [DIRS 169654]). Within these AC there are sub-criteria (1(1), 1(2), 1(3), 1(4), 1(7) and 2(1)) which are addressed below.

Acceptance Criterion 1(1) The total system performance assessment adequately incorporates, or bounds, important design features, physical phenomena, and couplings, and uses consistent and appropriate assumptions throughout the climate and net infiltration abstraction process

Appropriate assumptions has been identified in Section 5. The important physical phenomena involved in climate forecast for Yucca Mountain have been identified including atmospheric circulation (Section 6.2), Relationships between OIS and Devils Hole isotope levels (Section 6.3), Milankovitch Theory of orbital forcing for timing of change (Section 6.4), and regional climate response to insolation by orbital forcing (Section 6.5). All of these phenomena provide the basis for the climate forecast used to select climate states, timing of change from one state to another, and selection of analogue locations providing temperature and precipitation values. These results are provided in Section 6.6, Table 6-1 and output DTN: GS000308315121.003 for climate analyses supporting TSPA.

Acceptance Criterion 1(2) The aspects of geology, hydrology, geochemistry, physical phenomena, and couplings, that may affect climate and net infiltration, are adequately considered. Conditions and assumptions in the abstraction of climate and net infiltration are readily identified and consistent with the body of data presented in the description

As mentioned above, the processes and phenomena involved in the climate forecast have been addressed in Sections 6.2 through 6.5. The assumptions associated with this analysis are stated in Section 5 and are systematically addressed in Section 6. The resulting 10,000-year climate forecast in Section 6.6 is based on evidence that these assumptions are consistent with the body of data presented. 
Acceptance Criterion 1(3) The abstraction of climate and net infiltration uses assumptions, technical bases, data, and models that are appropriate and consistent with other related U.S. Department of Energy abstractions. For example, the assumptions used for climate and net infiltration Review Plan for Safety Analysis Report 2.2-61 are consistent with the abstractions of flow paths in the unsaturated zone and flow paths in the saturated zone (Sections 2.2.1.3.6 and 2.2.1.3.8 of the Yucca Mountain Review Plan, respectively). The descriptions and technical bases provide transparent and traceable support for the abstraction of climate and net infiltration

Assumptions supporting the future climate analysis are summarized in Section 5 and are appropriate and consistent with other related U.S. Department of Energy abstractions. In addition, the assumption that long-term, earth-based forcing functions (e.g. plate tectonics) will not change during the next 10,000 years is consistent with EPA proposed rule 40 CFR 197, 66 Federal Register 32073 (EPA 2001 [DIRS 157530]). Regarding the 10,000-year compliance period, the EPA states, "(2) There are likely to be no exceptionally large geologic changes during that time" [10 CFR Part 63, "Disposal of High-Level Radioactive Wastes in a Proposed Geologic Repository at Yucca Mountain, Nevada", page 32097 (NRC 1998 [DIRS 107770]).

Acceptance Criterion 1(4) Sufficient data and technical bases to assess the degree to which features, events, and processes have been included for this abstraction are provided

Sufficient technical bases have been presented in Section 6.6 to support the extent to which the FEPs related to climate change (FEP 1.3.01.00.0A) has been introduced in the beginning of Section 6 and addressed in Sections 6.6 and 7.1. This analysis forecasts future climate states, timing of those states, and the magnitude of the changes in temperature and precipitation in Section 6.6, Table 6-1, and output DTN: GS000308315121.003.

Acceptance Criterion 1(7) Projections of future climate change are based on evaluation of paleoclimate information over the past 500,000 years. For example, numerical climate models, if used for projection of future climate, are calibrated based on such paleoclimate data

The climate forecast presented for the next 10,000 years (Section 6.6) is based on the relevant paleoclimate records available (Sections 6.2, 6.3, 6.4, 6.5). These records include stable isotope data from marine sediment cores and Devils Hole (Section 6.3), earth-orbital precession (Section 6.4), as well as, fossil records form sediments from Owens Lake (Section 6.5). All of these records are for periods of time greater than 400,000 year ago. The 400,000-year time was selected from the past 500,000 year period based on cycles in earth-orbital precession.

Acceptance Criterion 2(1) Climatological and hydrological values used in the license application (e.g., time of onset of climate change, mean annual temperature, mean annual precipitation, mean annual net infiltration, etc.) are adequately justified. Adequate descriptions of how the data were used, interpreted, and appropriately synthesized into the parameters are provided. 
Forecasting the relevant climate states, the timing of the onset of change, and magnitude of changes in temperature and precipitation was the objective of this analysis. The values provided to support TSPA are in Section 6.6, Table 6-1, and output DTN: GS000308315121.003. The justification of these values is provided in Section 6.6 and is supported by the assumptions and discussion in Sections 5, 6.1, 6.2, 6.3, 6.4, and 6.5. The timing of climate change is addressed using Milankovitch Theory in Section 6.4, the magnitude of changes is discussed using lake fossils in Section (6.5), and the justification of selection of locations to represent temperature and precipitation is provided in Section 6.6. 


\section{INTENTIONALLY LEFT BLANK}




\section{INPUTS AND REFERENCES}

\subsection{DOCUMENTS CITED}

Ahrens, C.D. 1985. Meteorology Today, An Introduction to Weather, Climate, and

108848

the Environment. 2nd Edition. St. Paul, Minnesota: West Publishing. TIC: 246020.

Altman, W.D.; Donnelly, J.P.; and Kennedy, J.E. 1988. Peer Review for High-Level

103597

Nuclear Waste Repositories: Generic Technical Position. NUREG-1297. Washington, D.C.: U.S. Nuclear Regulatory Commission. TIC: 200651.

Altman, W.D.; Donnelly, J.P.; and Kennedy, J.E. 1988. Qualification of Existing Data

103750 for High-Level Nuclear Waste Repositories: Generic Technical Position. NUREG1298. Washington, D.C.: U.S. Nuclear Regulatory Commission. TIC: 200652.

Berger, A. and Loutre, M.F. 1991. "Insolation Values for the Climate of the Last 10 108910 Million Years." Quaternary Science Reviews, 10, 297-317. Oxford, United Kingdom: Pergamon Press. TIC: 234261.

Bradbury, J.P.; Forester, R.M.; and Thompson, R.S. 1989. "Late Quaternary Paleolimnology of Walker Lake, Nevada.” Journal of Paleolimnology, 1, (4), 249-267. Dordrecht, The Netherlands: Kluwer Academic Publishers. TIC: 223764.

BSC (Bechtel SAIC Company) 2004. Features, Events, and Processes in SZ Flow and 170013 Transport. ANL-NBS-MD-000002, Rev. 03. Las Vegas, Nevada: Bechtel SAIC Company.

BSC 2004. Features, Events, and Processes in UZ Flow and Transport. 170012 ANL-NBS-MD-000001, Rev. 03. Las Vegas, Nevada: Bechtel SAIC Company.

BSC (Bechtel SAIC Company) 2004. Q-List. 000-30R-MGR0-00500-000-000 REV 168361 00. Las Vegas, Nevada: Bechtel SAIC Company. ACC: ENG.20040721.0007.

BSC 2004. Simulation of Net Infiltration for Present-Day and Potential Future 170007 Climates. MDL-NBS-HS-000023 REV 00. Las Vegas, Nevada: Bechtel SAIC Company.

BSC 2004. Technical Work Plan for: Unsaturated Zone Flow Analysis and Model 169654 Report Integration. TWP-MGR-HS-000001 REV 00. Las Vegas, Nevada: Bechtel SAIC Company. ACC: DOC.20040701.0005.

BSC 2004. Total System Performance Assessment (TSPA) Model/Analysis for the License Application. MDL-WIS-PA-000004 REV 00. Las Vegas, Nevada: Bechtel 168504 SAIC Company. 
Canori, G.F. and Leitner, M.M. 2003. Project Requirements Document.

TER-MGR-MD-000001 REV 02. Las Vegas, Nevada: Bechtel SAIC Company.

ACC: DOC.20031222.0006.

Crowley, T.J. 2002. “Cycles, Cycles Everywhere.” Science, 295, (5559), 1473-1474.

160151

Washington, D.C.: American Association for the Advancement of Science.

TIC: 253326.

CRWMS (Civilian Radioactive Waste Management System) M\&O (Management and

100127

Operating Contractor) 1998. "Climatology and Meteorology." Book 2 - Section 4 of

Yucca Mountain Site Description. B00000000-01717-5700-00019 REV 00.

Las Vegas, Nevada: CRWMS M\&O. ACC: MOL.19980729.0050.

Delorme, L.D. 1970. "Freshwater Ostracodes of Canada. Part IV. Families

108953

Ilyocyprididae, Notodromadidae, Darwinulidae, Cytherideidae, and Entocytheridae."

Canadian Journal of Zoology, 48, (6), 1251-1259. Ottawa, Ontario, Canada: National

Research Council of Canada. TIC: 234265.

Delorme, L.D. 1989. "Methods in Quaternary Ecology \#7. Freshwater Ostracodes."

109421

Geoscience Canada, 16, (2), 85-90. St. Johns, Newfoundland, Canada: Geological Association of Canada. TIC: 245736.

Forester, R.M. 1983. "Relationship of Two Lacustrine Ostracode Species to Solute Composition and Salinity: Implications for Paleohydrochemistry." Geology, 11, (8), 435-438. Boulder, Colorado: Geological Society of America. TIC: 222805.

Forester, R.M. 1985. "Limnocythere bradburyi N. SP.: A Modern Ostracode from

109423

Central Mexico and a Possible Quaternary Paleoclimatic Indicator." Journal of Paleontology, 59, (1), 8-20. Tulsa, Oklahoma: Society of Economic Paleontologists and Mineralogists. TIC: 225826.

Forester, R.M. 1987. "Late Quaternary Paleoclimate Records from Lacustrine Ostracodes." Chapter 12 of North America and Adjacent Oceans During the Last Deglaciation. Ruddiman, W.F. and Wright, H.E., Jr., eds. Volume K-3.

Boulder, Colorado: Geological Society of America. TIC: 209437.

Forester, R.M.; Bradbury, J.P.; Carter, C.; Elvidge-Tuma, A.B.; Hemphill, M.L.; 109425

Lundstrom, S.C.; Mahan, S.A.; Marshall, B.D.; Neymark, L.A.; Paces, J.B.; Sharpe, S.E.; Whelan, J.F.; and Wigand, P.E. 1999. The Climatic and Hydrologic History of Southern Nevada During the Late Quaternary. Open-File Report 98-635. Denver, Colorado: U.S. Geological Survey. TIC: 245717.

Gauthier, J.H. 1999. "Unified Structure in Quaternary Climate.” Geophysical 109427 Research Letters, 26, (6), 763-766. Washington, D.C.: American Geophysical Union. TIC: 245706. 
Grootes, P.M. 1993. "Interpreting Continental Oxygen Isotope Records." Climate

Change in Continental Isotope Records. P.K. Swart, K.C. Lohmann, J.A. McKenzie, and S. Savin eds. Geophysical Monograph 78. 37-46. Washington, D.C.: American Geophysical Union. TIC: 234249.

Imbrie, J. and Imbrie, K.P. 1986. Ice Ages: Solving the Mystery. Cambridge, Massachusetts: Harvard University Press. TIC: 239939.

Imbrie, J.; Berger, A.; Boyle, E.A.; Clemens, S.C.; Duffy, A.; Howard, W.R.; Kukla, 109432 G.; Kutzback, J.; Martinson, D.G.; McIntyre, A.; Mix, A.C.; Molfino, B.; Morley, J.J.; Peterson, L.C.; Pisias, N.G.; Prell, W.L.; Raymo, M.E.; Shackleton, M.J.; and Toggweiler, J.R. 1993. "On the Structure and Origin of Major Glaciation Cycles, 2. The 100,000-Year Cycle.” Paleoceanography, 8, (6), 699-735. Washington, D.C.: American Geophysical Union. TIC: 245698.

Imbrie, J.; Boyle, E.A.; Clemens, S.C.; Duffy, A.; Howard, W.R.; Kukla, G.; 109430 Kutzbach, J.; Martinson, D.G.; McIntyre, A.; Mix, A.C.; Molfino, B.; Morley, J.J.; Peterson, L.C.; Pisias, N.G.; Prell, W.L.; Raymo, M.E.; Shackleton, M.J.; and Toggweiler, J.R. 1992. "On the Structure and Origin of Major Glaciation Cycles, 1. Linear Responses to Milankovitch Forcing." Paleoceanography, 7, (6), 701-738. Washington, D.C.: American Geophysical Union. TIC: 245699.

Imbrie, J.; Mix, A.C.; and Martinson, D.G. 1993. "Milankovitch Theory Viewed from 109118 Devils Hole." Nature, 363, (6429), 531-533. London, England: Macmillan Journals. TIC: 234192.

Jannik, N.O.; Phillips, F.M.; Smith, G.I.; and Elmore, D. 1991. "A 36Cl Chronology of Lacustrine Sedimentation in the Pleistocene Owens River System." Geological Society of America Bulletin, 103, 1146-1159. Boulder, Colorado: Geological Society of America. TIC: 245705.

Kay, P.A. 1982. "Perspective on Great Basin Paleoclimates." Man and Environment 109121 in the Great Basin. Madsen, D.B. and O'Connell, J.F., eds. SAA Paper No. 2. Pages 76-81. Washington, D.C.: Society of American Archaeology. TIC: 234650.

Kim, S.T. and O'Neil, J.R. 1997. "Equilibrium and Nonequilibrium Isotope Effects in 106367 Synthetic Carbonates." Geochimica et Cosmochimica Acta, 61, (16), 3461-3475. New York, New York: Pergamon Press. TIC: 236999.

Knott, J.R. 1999. "Quaternary Stratigraphy and Geomorphology of Death Valley." 109436 Proceedings of Conference on Status of Geologic Research and Mapping in Death Valley National Park, Las Vegas, Nevada, April 9-11, 1999. Slate, J.L., ed. Open-File Report 99-153. Pages 90-96. Denver, Colorado: U.S. Geological Survey. TIC: 245245. 
Ku, T-L.; Luo, S.; Lowenstein, T.K.; Li, J.; and Spencer, R.J. 1998. "U-Series

109438

Chronology of Lacustrine Deposits in Death Valley, California." Quaternary

Research, 50, 261-275. New York, New York: Academic Press. TIC: 245707.

Landwehr, J.M. and Winograd, I.J. 2001. "Dating the Vostok Ice Core Record by

160145

Importing the Devils Hole Chronology." Journal of Geophysical Research, 106,

(D23), 31,853-31,861. Washington, D.C.: American Geophysical Union. TIC:

253325.

Landwehr, J.M.; Coplen, T.B.; Ludwig, K.R.; Winograd, I.J.; and Riggs, A.C. 1997.

109124

Data for Devils Hole Core DH-11. Open-File Report 97-792. Reston, Virginia: U.S.

Geological Survey. TIC: 245712.

Litwin, R.J. 1999. E-mail Correspondence from Litwin, R.J. (U.S. Geological Survey)

138436

to Forester, R.M. (U.S. Geological Survey), November, 1999.

ACC: MOL.19991117.0153.

Litwin, R.J.; Smoot, J.P.; Durika, N.J.; and Smith, G.I. 1999. "Calibrating Late

109440

Quaternary Terrestrial Climate Signals: Radiometrically Dated Pollen Evidence from the Southern Sierra Nevada, USA.” Quaternary Science Reviews, 18, 1151-1171.

New York, New York: Pergamon Press. TIC: 245700.

Ludwig, K.R.; Simmons, K.R.; Szabo, B.J.; Winograd, I.J.; Landwehr, J.M.; Riggs,

104631 A.C.; and Hoffman, R.J. 1992. "Mass-Spectrometric ${ }^{230} \mathrm{Th}-{ }^{234} \mathrm{U}-{ }^{238} \mathrm{U}$ Dating of the Devils Hole Calcite Vein.” Science, 258, 284-287. Washington, D.C.: American Association for the Advancement of Science. TIC: 237796.

Markgraf, V.; Bradbury, J.P.; Forester, R.M.; Singh, G.; and Sternberg, R.S. 1984. "San Agustin Plains, New Mexico: Age and Paleoenvironmental Potential Reassessed." Quaternary Research, 22, 336-343. New York, New York: Academic Press. TIC: 245708.

Menking, K.M.; Bischoff, J.L.; Fitzpatrick, J.A.; Burdette, J.W.; and Rye, R.O. 1997. 109444 "Climatic/Hydrologic Oscillations Since 155,000 Yr B.P. at Owens Lake, California, Reflected in Abundance and Stable Isotope Composition of Sediment Carbonate." Quaternary Research, 48, (1), 58-68. Orlando, Florida: Academic Press.

TIC: 236972.

Muhs, D.R. 1999. E-mail Correspondence Between D.R. Muhs (U.S. Geological 128077 Survey) and R.M. Forester (U.S. Geological Survey), August 2, 1999. ACC: MOL.19991117.0154.

Muhs, D.R. and Szabo, B.J. 1994. "New Uranium-Series Ages of the Waimanalo Limestone, Oahu, Hawaii: Implications for Sea Level During the Last Interglacial Period." Marine Geology, 118, 315-326. Amsterdam, The Netherlands: Elsevier. TIC: 245704. 
NRC (U.S. Nuclear Regulatory Commission) 2003. Yucca Mountain Review Plan,

Final Report. NUREG-1804, Rev. 2. Washington, D.C.: U.S. Nuclear Regulatory Commission, Office of Nuclear Material Safety and Safeguards. TIC: 254568.

NRC 1997. Issue Resolution Status Report on Methods to Evaluate Climate Change 100408 and Associated Effects at Yucca Mountain (Key Technical Issue: Unsaturated and Saturated Flow Under Isothermal Conditions). Washington, D.C.: U.S. Nuclear Regulatory Commission. ACC: MOL.19980219.0880.

Oviatt, C.G.; Thompson, R.S.; Kaufman, D.S.; Bright, J.; and Forester, R.M. 1999. "Reinterpretation of the Burmester Core, Bonneville Basin, Utah." Quaternary Research, 52, (2), 180-184. San Diego, California: Academic Press. TIC: 245885.

Petit, J.R.; Jouzel, J.; Raynaud, D.; Barkov, N.I.; Barnola, J.-M.; Basile, I.; Bender, M.; Chappellaz, J.; Davis, M.; Delaygue, G.; Delmotte, M.; Kotlyakov, V.M.; Legrand, M.; Lipenkov, V.Y.; Lorius, C.; Pepin, L.; Ritz, C.; Saltzman, E.; and Stievenard, M. 1999. "Climate and Atmospheric History of the Past 420,000 Years from the Vostok Ice Core, Antarctica.” Nature, 399, (6735), 429-436. London, England: Macmillan Magazines. TIC: 245695.

Reheis, M. 1999. "Highest Pluvial-Lake Shorelines and Pleistocene Climate of the Western Great Basin.” Quaternary Research, 52, (2), 196-205. New York, New York: Academic Press. TIC: 245885.

Reheis, M.C.; Slate, J.L.; Sarna-Wojcicki, A.M.; and Meyer, C.E. 1993. "A Late 109452 Pliocene to Middle Pleistocene Pluvial Lake in Fish Lake Valley, Nevada and California." Geological Society of America Bulletin, 105, 953-967. Boulder, Colorado: Geological Society of America. TIC: 245702.

Shackleton, N.J. and Opdyke, N.D. 1973. "Oxygen Isotope and Palaeomagnetic 109163 Stratigraphy of Equatorial Pacific Core V28-238: Oxygen Isotope Temperatures and Ice Volumes on a $10^{5}$ and $10^{6}$ Year Scale." Quaternary Research, 3, 39-55. New York, New York: Academic Press. TIC: 225720.

Shaffer, J.A.; Cerveny, R.S.; and Dorn, R.I. 1996. "Radiation Windows as Indicators 109164 of an Astronomical Influence on the Devil's Hole Chronology." Geology, 24, (11), 1017-1020. Boulder, Colorado: Geological Society of America. TIC: 237308.

Sharpe, S. 2003. Future Climate Analysis-10,000 Years to 1,000,000 Years After 161591 Present. MOD-01-001 REV 01. Reno, Nevada: Desert Research Institute. ACC: MOL.20030407.0055.

Smith, A.J. and Forester, R.M. 1994. "Estimating Past Precipitation and Temperature 109456 from Fossil Ostracodes." High Level Radioactive Waste Management, Proceedings of the Fifth Annual International Conference, Las Vegas, Nevada, May 22-26, 1994. 4, 2545-2552. La Grange Park, Illinois: American Nuclear Society. TIC: 210984. 
Smith, G.I. 1991. "Continental Paleoclimatic Records and Their Significance."

Smith, G.I. 1991. "Stratigraphy and Chronology of Quaternary-Age Lacustrine

Deposits." Quaternary Nonglacial Geology: Conterminous U.S. Morrison, R.B., ed.

The Geology of North America Volume K-2. Boulder, Colorado: Geological Society of America. TIC: 240796.

Smith, G.I. 1984. "Paleohydrologic Regimes in the Southwestern Great Basin, 0-3.2

109168 my Ago, Compared with Other Long Records of 'Global' Climate." Quaternary Research, 22, 1-17. New York, New York: Academic Press. TIC: 219152.

Smith, G.I. 1976. "Paleoclimatic Record in the Upper Quaternary Sediments of 109167 Searles Lake, California, U.S.A.” Paleolimnology of Lake Biwa and the Japanese Pleistocene. Horie, S., ed. 4, 577-604. Otsu, Japan: Kyoto University, Otsu Hydrobiological Station. TIC: 234339.

Smith, G.I. and Bischoff, J.L., eds. 1997. An 800,000-Year Paleoclimatic Record from 109480 Core OL-92, Owens Lake, Southeast California. Geological Society of America, Special Paper 317. Boulder, Colorado: Geological Society of America. TIC: 236857.

Stanhill, G. 1999. "Climate Change Science is Now Big Science.” Eos, 80, (35), 396-397. Washington, D.C.: American Geophysical Union. TIC: 246248.

Szabo, B.J.; Ludwig, K.R.; Muhs, D.R.; and Simmons, K.R. 1994. "Thorium-230 Ages of Corals and Duration of the Last Interglacial Sea-Level High Stand on Oahu, Hawaii." Science, 266, 93-96. Washington, D.C.: American Association for the Advancement of Science. TIC: 245710.

Thompson, L.G.; Yao, T.; Davis, M.E.; Henderson, K.A.; Mosley-Thompson, E.; Lin, 109460 P.-N.; Beer, J.; Synal, H.-A.; Cole-Dai, J.; and Bolzan, J.F. 1997. "Tropical Climate Instability: The Last Glacial Cycle from a Qinghai-Tibetan Ice Core." Science, 276, (5313), 1821-1825. Washington, D.C.: American Association for the Advancement of Science. TIC: 245709.

Thompson, R.S.; Anderson, K.H.; and Bartlein, P.J. 1999. Atlas of Relations Between 109462 Climatic Parameters and Distributions of Important Trees and Shrubs in North America - Introduction and Conifers. Professional Paper 1650-A. Washington, D.C.: U.S. Geological Survey. TIC: 245909.

Thompson, R.S.; Anderson, K.H.; and Bartlein, P.J. 1999. Quantitative Paleoclimatic Reconstructions from Late Pleistocene Plant Macrofossils of the Yucca Mountain Region. Open-File Report 99-338. Denver, Colorado: U.S. Geological Survey. ACC: MOL.19991015.0296. 
U.S. Department of Commerce, Environmental Science Services Administration 1970.109416 Climatological Data. Volume 73, No. 13, California Annual Summary 1969. Asheville, North Carolina: U.S. Department of Commerce. TIC: 245691.

U.S. Department of Commerce, National Oceanic and Atmospheric Administration 109417 1977. Climatological Data. Volume 80, No.13, California Annual Summary 1976. Asheville, North Carolina: Department of Commerce. TIC: 245694.

U.S. Department of Commerce, National Oceanic and Atmospheric Administration 1978. Climatological Data. Volume 81, No.13 California Annual Summary 1977. Asheville, North Carolina: U.S. Department of Commerce. TIC: 245692.

U.S. Department of Commerce, Weather Bureau 1964. Climatological Data. 109414 Volume 67, No.13, California Annual Summary 1963. Asheville, North Carolina: U.S. Department of Commerce. TIC: 245690.

Whitney, J.W. and Harrington, C.D. 1993. "Relict Colluvial Boulder Deposits as Paleoclimatic Indicators in the Yucca Mountain Region, Southern Nevada." Geological Society of America Bulletin, 105, 1008-1018. Boulder, Colorado: Geological Society of America. TIC: 208099.

Winograd, I.J.; Coplen, T.B.; Landwehr, J.M.; Riggs, A.C.; Ludwig, K.R.; Szabo, B.J.; Kolesar, P.T.; and Revesz, K.M. 1992. "Continuous 500,000-Year Climate Record from Vein Calcite in Devils Hole, Nevada.” Science, 258, 255-260. Washington, D.C.: American Association for the Advancement of Science. TIC: 237563 .

Winograd, I.J.; Coplen, T.B.; Ludwig, K.R.; Landwehr, J.M.; and Riggs, A.C. 1996. "High Resolution $\delta^{18} \mathrm{O}$ Record from Devils Hole, Nevada, for the Period 80 to 19 Ka." Eos, Transactions (Supplement), 1996 Spring Meeting, May 20-24, Baltimore, Maryland. Page S169. Washington, D.C.: American Geophysical Union.

TIC: 245711.

Winograd, I.J.; Landwehr, J.M.; Ludwig, K.R.; Coplen, T.B.; and Riggs, A.C. 1997. "Duration and Structure of the Past Four Interglaciations." Quaternary Research, 48, 141-154. New York, New York: Academic Press. TIC: 236777.

Winograd, I.J.; Riggs, A.C.; and Coplen, T.B. 1998. "The Relative Contributions of 109466 Summer and Cool-Season Precipitation to Groundwater Recharge, Spring Mountains, Nevada, USA.” Hydrogeology Journal, 6, 77-93. Berlin, Germany: Springer-Verlag. TIC: 245701. 


\subsection{CODES, STANDARDS, REGULATIONS, AND PROCEDURES}

10 CFR 63. Energy: Disposal of High-Level Radioactive Wastes in a Geologic

Repository at Yucca Mountain, Nevada. Readily available.

40 CFR 197. 2001. Protection of Environment: Public Health and Environmental

155238

Radiation Protection Standards for Yucca Mountain, Nevada. Readily available.

AP-2.22Q, Rev. 1, ICN 1. Classification Analyses and Maintenance of the Q-List. Washington, D.C.: U.S. Department of Energy, Office of Civilian Radioactive Waste Management. ACC: DOC.20040714.0002.

AP-SIII.9Q, Rev 1, ICN 6. Scientific Analyses. Washington, D.C.: U.S. Department of Energy, Office of Civilian Radioactive Waste Management. ACC: DOC.20040805.0003.

LP-SI.11Q-BSC, Rev. 0, ICN 0. Software Management. Washington, D.C.: U.S. Department of Energy, Office of Civilian Radioactive Waste Management. ACC: DOC.20040225.0007.

\subsection{SOURCE DATA, LISTED BY DATA TRACKING NUMBER}

GS000100001221.001. EarthInfo, Inc. Western US Meteorologic Station Weather 146816 Data - NCDC Summary of Day (West 1) and NCDC Summary of Day (West 2).

Submittal date: $01 / 25 / 2000$.

GS000200005121.001. Earth Orbital Parameter Data for the Last 10 Million Years. 146818 Submittal date: 03/06/2000.

GS000200005121.002. Earth Orbital Parameter Data for the Present to 100,000 Years 146817 in the Future. Submittal date: 03/06/2000.

GS000200005121.003. Radiometric Dating and 180 Data from Devils Hole, Nevada. 146819 Submittal date: 03/06/2000.

GS030908315121.001. DIATOM Data from Owens Lake 1984-1992 Cores.

Submittal date: 11/04/2003.

GS031108315121.002. Supplementary Data to Diatom Data from Owens Lake

170227 1984-1992 Cores. Submittal date: 12/18/2003.

GS031108315121.003. Supplementary Data to Ostracode Data from Owens Lake 168533 1984-1992 Cores. Submittal date: 02/09/2004.

GS970708315121.002. Ostracode Data from Owens Lake 1984-1992 Cores. 106508 Submittal date: 07/31/1997.

MO0407SEPFEPLA.000. LA FEP List. Submittal date: 07/20/2004.

170760 


\subsection{OUTPUT DATA, LISTED BY DATA TRACKING NUMBER}

GS000308315121.003. Meteorological Stations Selected to Represent Future Climate States at Yucca Mountain, Nevada. Submittal date: 03/14/2000. 


\section{INTENTIONALLY LEFT BLANK}


APPENDIX A

INTERNAL QUALIFICATIONS 


\section{INTERNAL QUALIFICATIONS}

\section{Reference Citation}

Litwin, R.J.; Smoot, J.P.; Durika, N.J.; and Smith, G.I. 1999. "Calibrating Late Quaternary Terrestrial Climate Signals: Radiometrically Dated Pollen Evidence from the Southern Sierra Nevada, USA." Quaternary Science Reviews, 18, 1151-1171. New York, New York: Pergamon Press. TIC: 245700 (Litwin et al. 1999 [DIRS 109440]).

\section{Description of Use}

This reference provides a sedimentation rate for the Owens Lake record; a record including fossils used as evidence for forecasting future climate. The sedimentation rates were estimated in Litwin et al. (1999 [DIRS 109440]) based on pollen records in the sediment core samples and are presented in Table 4-1. The Holocene Intervals $1^{\Delta}$ and also Interval $5^{\Delta}$ of 60,66 , $64.3 \mathrm{~cm} / \mathrm{kyr}$ (1000 years) were averaged to result in a $63 \mathrm{~cm} / \mathrm{kyr}$ sedimentation rate estimate for the Owens Lake record (DTN: GS031108315121.003 [DIRS 168533]) that corresponds to the 10,000-year analogue used in this future climate analysis. This sedimentation rate is used to estimate the timing of transitions between climate states in output DTN: GS000308315121.003.

\section{Extent to which the Data Demonstrate the Properties of Interest}

This report presents a sedimentation rate for the identical location of the Owens Lake OL-92 cores used in the analysis report. This information provides a means to estimate timing of changes in ostracode abundances provided in Yucca Mountain Project DTN: GS031108315121.003 [DIRS 168533], so that a chorology may be developed for the future climate forecast. The $63 \mathrm{~cm} / \mathrm{kyr}$ sedimentation rate was estimated using extensive analysis of pollen interval boundaries, radiometric dating of the pollen, and additional evidence from literature. The result is corroborated by comparison to pollen records for a close by location (Searles Lake). The analysis is consistent with methods used in this scientific field.

\section{Qualifications of Personnel and Organizations Generating the Data}

United States Geological Survey has a long and respectable research history in a broad range of earth science related subjects. Ronald J. Litwin, Joseph P. Smoot, and Nancy J. Durika are geologist at the United States Geological Survey in Reston, Virginia. George I. Smith is a geologist at the United States Geological Survey in Menlo Park, California. Ronald Litwing has authored a number of scientific journal articles on the subjects of palynology, plant biostratigraphy, and paleoclimate and recently coauthored a book on these subjects in relation to dinosaurs. Joseph Smoot has coauthored five articles on lake sedimentation records in the last 10 years. George Smith's research focuses on the application of stable isotopes to identify earth processes with more than 7 scientific publications on the subject in the past 10 years. 


\section{Reference Citation}

Forester, R.M.; Bradbury, J.P.; Carter, C.; Elvidge-Tuma, A.B.; Hemphill, M.L.; Lundstrom, S.C.; Mahan, S.A.; Marshall, B.D.; Neymark, L.A.; Paces, J.B.; Sharpe, S.E.; Whelan, J.F.; and Wigand, P.E. 1999. The Climatic and Hydrologic History of Southern Nevada During the Late Quaternary. Open-File Report 98-635. Denver, Colorado: U.S. Geological Survey. TIC: 245717. (Forester et al. 1999 [DIRS 109425]).

\section{Description of Use}

This reference is the source for Figure 6-12 and is used as corroborating evidence throughout the document. This USGS Open File Report was the original reference that presented much of the information used for this future climate forecast and Forester was the original author for the first revision of this report. The interpretation of the Ostracode sedimentation data and marine isotope data depend on this analysis.

\section{Extent to which the Data Demonstrate the Properties of Interest}

This USGS Open File Report was the original reference that presented much of the information used for this future climate forecast and Forester was the original author for the first revision of this report. It contains information on Milankovitch forcing, marine isotope stages, Devil's Hole data, Owens Lake data, and comparison to other examples in the literature.

\section{Qualifications of Personnel and Organizations Generating the Data}

United States Geological Survey has a long and respectable research history in a broad range of earth science related subjects. Dr. Rick Forester is a respected USGS paleoclimatologist with more that 9 scientific journal articles published in the last ten years. J Platt Bradbury was a USGS paleolimnologist with more than 21 scientific journal articles in the last 10 years. Dr. Saxon Sharpe is a scientist at the Desert Research Institute in Las Vegas NV, and is the author of the Sharpe 2003 [DIRS 161591] a corroborating future climate analysis for Yucca Mountain. Dr. Brian Marshall, Dr. Leonid Neymark, Dr. Joe Whelan, and Dr. James Paces are USGS isotope geochemists with numerous excellent scientific journal articles, many on Yucca Mountain. They have worked on the Yucca Mountain Project for many years under the guidance of Dr. Zell Peterman.

\section{Reference Citation}

Landwehr, J.M.; Coplen, T.B.; Ludwig, K.R.; Winograd, I.J.; and Riggs, A.C. 1997. Data for Devils Hole Core DH-11. Open-File Report 97-792. Reston, Virginia: U.S. Geological Survey. TIC: 245712. (Landwehr et al. 1997 [DIRS 109124], data tracking number (DTN): GS000200005121.003 [DIRS 146819]) 


\section{Description of Use}

This source provides the raw data on ${ }^{18} \mathrm{O}$ and radiometric dating from the Devils Hole cores. The summarized data is illustrated in Figure 6-3. The data are used throughout the report in formulating the climatic history of the region and the selection analog climates for the future climate forecast.

\section{Extent to which the Data Demonstrate the Properties of Interest}

Devils Hole is in close proximity to Yucca Mountain and provides a long, continuous history of climatic variation during the late Quaternary. There are few locations that can supply this type of information. The isotopic and radiometric dating contained in this source are key to interpreting the climatic history at this location.

\section{Reliability of the Data Source}

The radiometric and stable isotope data were collected in U.S. Government laboratories using state of the art equipment and techniques. The data were rigorously checked for accuracy and the stable isotopic data were rerun a second time at a later date to assure reproducibility. Appropriate standards were used in the respective laboratories. Because the interpretation of the timing of climatic change derived from this record differed from conventional thinking at the time about the causes and timing of climate change, this particular set of data were reviewed and evaluated extensively not only by the USGS and for presentation in peer-reviewed journals, but by extensive discussion in the open literature. The data have withstood this detailed scrutiny and are considered accurate by conventional standard for these types of measurements.

\section{Qualifications of Personnel and Organizations Generating the Data}

United States Geological Survey has a long and respectable research history in a broad range of earth science related subjects. All of the authors are current or former USGS research scientists with extensive backgrounds in isotopic determinations, geochronology, or hydrology.

\section{Prior Uses of the Data}

These data have been used in several publications related to Devils Hole (e.g., Winograd et al. 1997 [DIRS 100096], Ludwig et al. 1992 [DIRS 104631]). In addition, the data have been used as the basis for dating other paleoclimatic records [e.g., "Dating the Vostok Ice Core Record by Importing the Devils Hole Chronology" (Landwehr and Winograd 2001[DIRS 160145], pp. 31,853-31,862)]. 


\section{INTENTIONALLY LEFT BLANK}

